Prepared in cooperation with the Kentucky Energy and Environment Cabinet, Division of Water

\title{
Methods for Estimating Selected Low-Flow Frequency Statistics for Unregulated Streams in Kentucky
}

Scientific Investigations Report 2010-5217 



\section{Methods for Estimating Selected Low-Flow Frequency Statistics for Unregulated Streams in Kentucky}

By Gary R. Martin and Leslie D. Arihood

Prepared in cooperation with the Kentucky Energy and Environment Cabinet, Division of Water

Scientific Investigations Report 2010-5217

U.S. Department of the Interior

U.S. Geological Survey 


\section{U.S. Department of the Interior \\ KEN SALAZAR, Secretary \\ U.S. Geological Survey \\ Marcia K. McNutt, Director}

U.S. Geological Survey, Reston, Virginia: 2010

For more information on the USGS—-the Federal source for science about the Earth, its natural and living resources,
natural hazards, and the environment, visit http://www.usgs.gov or call 1-888-ASK-USGS
For an overview of USGS information products, including maps, imagery, and publications,
visit http://www.usgs.gov/pubprod
To order this and other USGS information products, visit http://store.usgs.gov

Any use of trade, product, or firm names is for descriptive purposes only and does not imply endorsement by the U.S. Government.

Although this report is in the public domain, permission must be secured from the individual copyright owners to reproduce any copyrighted materials contained within this report.

Suggested citation:

Martin, G.R., and Arihood, L.D., 2010, Methods for estimating selected low-flow frequency statistics for unregulated streams in Kentucky: U.S. Geological Survey Scientific Investigations Report 2010-5217, 83 p. 


\section{Contents}

Abstract

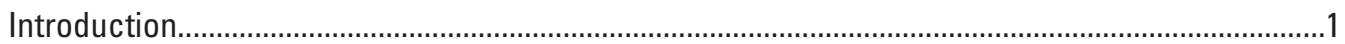

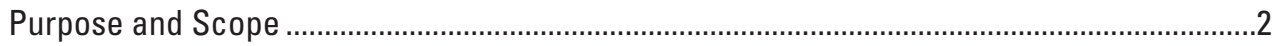

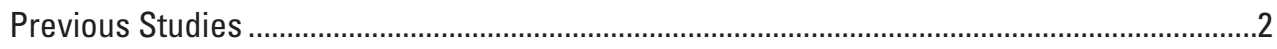

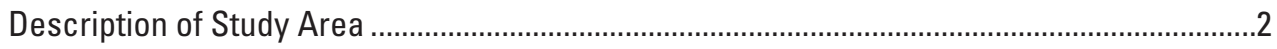

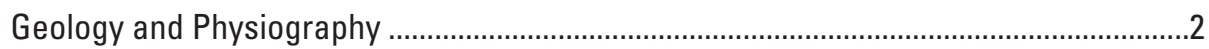

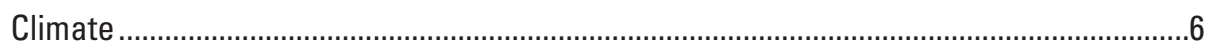

Methods for Data-Collection Stations ....................................................................................

Long-Term Continuous-Record Streamflow-Gaging Stations .................................................

Assessment of the Annual Low-Flow Time-Series Data ...................................................

Combining Low-Flow Streamflow-Gaging-Station Records.............................................11

Low-Flow Partial-Record Streamflow-Gaging Stations .........................................................11

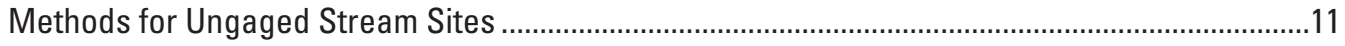

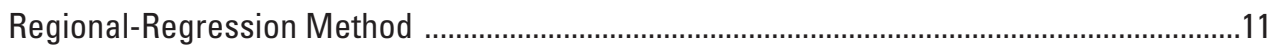

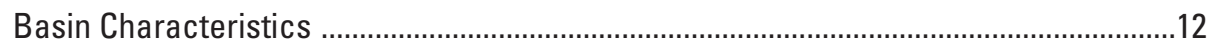

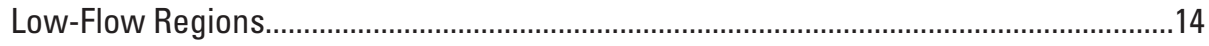

Logistic-Regression Analysis ..................................................................................14

Multiple-Linear-Regression Analysis ......................................................................19

Limitations and Accuracy of the Estimating Equations ...............................................20

Example Applications of the Estimating Equations .......................................................27

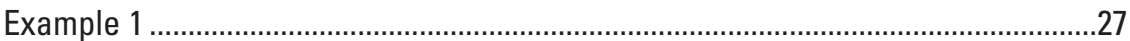

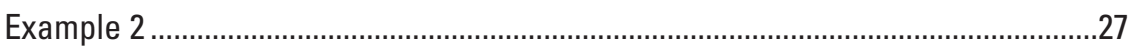

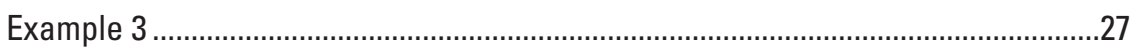

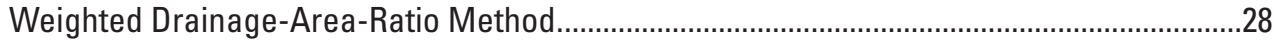

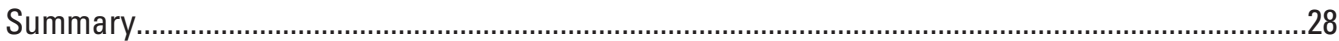

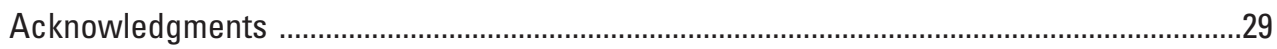

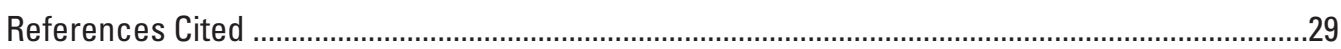

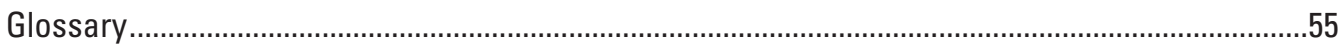

Appendix 1. Trend Tests of Long-Term Climate Data for Kentucky During 1895-2004 ..................57

Appendix 2. Trend-Test Screening of Annual 7-Day Low Flows for Selected Long-Term Continuous-Record Streamflow-Gaging Stations in Kentucky for Various Periods of Record.

Appendix 3. Double-Mass Curves Showing Relations of Cumulative Annual 7-Day Low Flows among Selected Hydro-Climate Data Network, Hydrologic Benchmark Network, and Reference Streamflow-Gaging Stations in and surrounding Kentucky .....

Appendix 4. A Procedure for Detrending Annual Low-Flow Data for Frequency Analysis .........77

Appendix 5. Classification Tables for Logistic-Regression Equations for Estimating the Probability of Zero Flow For Selected Low-Flow Frequencies in Kentucky.............79 


\section{Plates}

1. Map showing location of the streamflow-gaging stations used in the low-flow regression analyses in Kentucky. see link on HTML index page

2. Map showing location of the streamflow-variability-index boundaries in Kentucky and in contributing drainage basins in adjacent states see link on HTML index page

\section{Figures}

1-3. Maps showing:

1. Major drainage basins in Kentucky ....................................................................

2. Physiographic regions in Kentucky ...................................................................

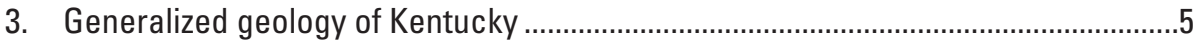

4-7. Graphs showing:

4. Annual temperature and precipitation with a LOWESS curve fit to the data for the period 1890-2004 in Kentucky....

5. LOWESS curves fit to the standardized Kentucky annual mean temperature, total precipitation, and 7-day low flows at South Fork Cumberland River near Stearns, Kentucky (station number 03410500).

6. Annual mean 1-day low flows, LOWESS curve fit to low flows at station South Fork Kentucky River at Booneville, Kentucky (03281500), and doublemass curve comparing cumulative annual 1-day mean low flows at the selected station and the reference station South Fork Cumberland River near Stearns, Kentucky (03410500), showing three periods of homogeneous low flows during 1926-60, 1967-89, and 1990-2006.

7. Relation between 7-day, 10-year low-flow yield and streamflow-variability index.

8A-C. Maps showing locations of the low-flow regions in Kentucky:

$8 \boldsymbol{A}$. Regions 1,2 , and 3

8B. Region 2 enlarged view (Cumberland Plateau vicinity).

8C. Region 3 enlarged view (Mississippian Plateau vicinity)

9-11. Graphs showing:

9. Total-drainage-area and mapped streamflow-variability-index sample space for the logistic-regression equations for estimating the probability of zero flow for unregulated streams in Kentucky

10. Total-drainage-area and mapped streamflow-variability-index sample spaces for 30-day, 2-year and 7-day, 10-year low-flow-frequency estimating equations for unregulated streams in Kentucky

11. Comparison of selected low-flow frequencies estimated from measured streamflow and from regression equations for unregulated streams in Kentucky.

12-13. Maps showing:

12. Residuals for the 30-day, 2-year low-flow regressions in Kentucky........................25

13. Residuals for the 7-day, 10-year low-flow regressions in Kentucky........................26 


\section{Tables}

1. Description of streamflow-gaging stations evaluated for use in the low-flow regressions in Kentucky

2. Low-flow frequencies for streamflow-gaging stations used in the low-flow regressions in Kentucky.

3. Basin characteristics tested for use in the low-flow regression analyses in Kentucky.

4. Logistic-regression equations for estimating the annual probability of zero flow for selected low-flow frequencies for unregulated streams in Kentucky

5. Weighted-least-squares regression equations for estimating selected nonzero low-flow frequencies for unregulated streams statewide and in each low-flow region in Kentucky...

6. Basin-characteristic ranges for the logistic-regression equations for estimating the annual probability of zero flow for selected low-flow frequencies and the weighted-least-squares regression equations for estimating selected nonzero low-flow frequencies for unregulated streams statewide and in each low-flow region in Kentucky.......

\section{Appendix Figures}

3-1 to 4-1. Graphs showing:

3-1. Annual 7-day low-flow time series with LOWESS curve and doublemass plots versus reference station South Fork Cumberland River near Stearns, Kentucky (03410500), for $\boldsymbol{A}$, Greenbrier River at Alderson, West Virginia; B, Twin Creek near Germantown, Ohio; $\boldsymbol{C}$, Cataloochee Creek near Cataloochee, North Carolina; and $\boldsymbol{D}$, Clinch River above Tazewell, Tennessee

3-2. Annual 7-day low-flow time series with LOWESS curve and doublemass plots versus reference station South Fork Cumberland River near Stearns, Kentucky (03410500), for $\boldsymbol{A}$, Tellico River at Tellico Plains, Tennessee; $\boldsymbol{B}$, Little Wabash River below Clay City, Illinois (03379500); $\boldsymbol{C}$, Little River above Townsend, Tennessee; and $\boldsymbol{D}$, North Sylamore Creek near Fifty-Six, Arkansas

3-3. Double-mass plots of cumulative annual 7-day low flows for $\boldsymbol{A}$, Twin Creek near Germantown, Ohio, versus Greenbrier River at Alderson, West Virginia; $\boldsymbol{B}$, Powell River near Jonesville, Virginia, versus Clinch River above Tazewell, Tennessee; and $\boldsymbol{C}$, Tellico River at Tellico Plains, Tennessee, versus Nolichucky River at Embreeville, Tennessee

4-1. Adjustments of annual 7-day low flows and estimates of mean, standard deviation, and skew of the logarithms of annual 7-day low flows at Mayfield Creek at Lovelaceville, Kentucky (07023000) for basin conditions in 1972 


\section{Appendix Tables}

1-1. Summary of trends and trend-test $p$-values in statewide monthly and annual temperature and precipitation data for 1895-2004 in Kentucky

2-1. Trend-test screening of annual 7-day low flows for selected long-term continuous-record streamflow-gaging stations in Kentucky for various periods of record

5-1. Classification table for the logistic-regression equation for estimating zero-flow probability for the 30-day, 2-year low flow in Kentucky.....

5-2. Classification table for the logistic-regression equation for estimating zero-flow probability for the 30-day, 5-year low flow in Kentucky

5-3. Classification table for the logistic-regression equation for estimating zero-flow probability for the 7-day, 2-year low flow in Kentucky

5-4. Classification table for the logistic-regression equation for estimating zero-flow probability for the 7-day, 10-year low flow in Kentucky.

5-5. Classification table for the logistic-regression equation for estimating zero-flow probability for the 7-day, 20-year low flow in Kentucky

\section{Conversion Factors}

\begin{tabular}{|c|c|c|}
\hline Multiply & By & To obtain \\
\hline \multicolumn{3}{|c|}{ Length } \\
\hline inch (in.) & 25.4 & millimeter $(\mathrm{mm})$ \\
\hline foot $(\mathrm{ft})$ & 0.3048 & meter $(\mathrm{m})$ \\
\hline mile (mi) & 1.609 & kilometer (km) \\
\hline \multicolumn{3}{|c|}{ Area } \\
\hline square mile $\left(\mathrm{mi}^{2}\right)$ & 2.590 & square kilometer $\left(\mathrm{km}^{2}\right)$ \\
\hline \multicolumn{3}{|c|}{ Flow rate } \\
\hline cubic foot per second $\left(\mathrm{ft}^{3} / \mathrm{s}\right)$ & 0.02832 & cubic meter per second $\left(\mathrm{m}^{3} / \mathrm{s}\right)$ \\
\hline $\begin{array}{l}\text { cubic foot per second per square mile } \\
{\left[\left(\mathrm{ft}^{3} / \mathrm{s}\right) / \mathrm{mi}^{2}\right]}\end{array}$ & 0.01093 & $\begin{array}{l}\text { cubic meter per second per square } \\
\text { kilometer }\left[\left(\mathrm{m}^{3} / \mathrm{s}\right) / \mathrm{km}^{2}\right]\end{array}$ \\
\hline million gallons per day (Mgal/d) & 0.04381 & cubic meter per second $\left(\mathrm{m}^{3} / \mathrm{s}\right)$ \\
\hline
\end{tabular}

Temperature in degrees Fahrenheit $\left({ }^{\circ} \mathrm{F}\right)$ may be converted to degrees Celsius $\left({ }^{\circ} \mathrm{C}\right)$ as follows:

${ }^{\circ} \mathrm{C}=\left({ }^{\circ} \mathrm{F}-32\right) / 1.8$

Elevation, as used in this report, refers to the distance in feet above the National Geodetic Vertical Datum of 1929 (NGVD 1929).

Horizontal coordinate information is referenced to the North American Datum of 1983 (NAD 83). 


\title{
Methods for Estimating Selected Low-Flow Frequency Statistics for Unregulated Streams in Kentucky
}

\author{
By Gary R. Martin and Leslie D. Arihood
}

\section{Abstract}

This report provides estimates of, and presents methods for estimating, selected low-flow frequency statistics for unregulated streams in Kentucky including the 30-day mean low flows for recurrence intervals of 2 and 5 years $\left(30 Q_{2}\right.$ and $30 Q_{5}$ ) and the 7-day mean low flows for recurrence intervals of 5,10 , and 20 years $\left(7 Q_{2}, 7 Q_{10}\right.$, and $\left.7 Q_{20}\right)$. Estimates of these statistics are provided for 121 U.S. Geological Survey streamflow-gaging stations with data through the 2006 climate year, which is the 12-month period ending March 31 of each year. Data were screened to identify the periods of homogeneous, unregulated flows for use in the analyses.

Logistic-regression equations are presented for estimating the annual probability of the selected low-flow frequency statistics being equal to zero. Weighted-least-squares regression equations were developed for estimating the magnitude of the nonzero $30 \mathrm{Q}_{2}, 30 \mathrm{Q}_{5}, 7 \mathrm{Q}_{2}, 7 \mathrm{Q}_{10}$, and $7 \mathrm{Q}_{20}$ low flows. Three low-flow regions were defined for estimating the 7-day lowflow frequency statistics.

The explicit explanatory variables in the regression equations include total drainage area and the mapped streamflowvariability index measured from a revised statewide coverage of this characteristic. The percentage of the station low-flow statistics correctly classified as zero or nonzero by use of the logistic-regression equations ranged from 87.5 to 93.8 percent. The average standard errors of prediction of the weightedleast-squares regression equations ranged from 108 to 226 percent. The $30 \mathrm{Q}_{2}$ regression equations have the smallest standard errors of prediction, and the $7 \mathrm{Q}_{20}$ regression equations have the largest standard errors of prediction.

The regression equations are applicable only to stream sites with low flows unaffected by regulation from reservoirs and local diversions of flow and to drainage basins in specified ranges of basin characteristics. Caution is advised when applying the equations for basins with characteristics near the applicable limits and for basins with karst drainage features.

\section{Introduction}

Information on streamflow characteristics, such as lowflow frequency statistics, is needed for effective management of water resources. Decisions related to waste-load allocations, discharge and withdrawal permits, water-supply planning, and in-stream flow requirements depend on estimates of low-flow frequency statistics; and methods for estimating these statistics at gaged stream sites are part of this need. The U.S. Geological Survey (USGS), in cooperation with the Kentucky Division of Water (KDOW), made estimates of the $30 \mathrm{Q}_{2}, 30 \mathrm{Q}_{5}, 7 \mathrm{Q}_{2}, 7 \mathrm{Q}_{10}$, $7 \mathrm{Q}_{20}$ low flows at 121 streamflow-gaging stations with data through the 2006 climate year (the 12-month period ending March 31 of each year) and developed regional regression equations for estimating these low-flow frequency statistics for unregulated streams in Kentucky.

Frequency analysis in water-resource studies associates an estimate of flow magnitude to a frequency of occurrence. The more extreme the flow (flood or drought), the smaller the estimated frequency of occurrence (and annual probability, p) and the larger the recurrence interval (T). A low-flow frequency statistic, such as the 7-day, 10-year low flow (abbreviated as $7 Q_{10}$ ), is estimated from the series of annual minimum mean flows for a specific number of consecutive days -7 days for $7 Q_{10}$. The 7-day mean flows are computed for the entire daily mean flow record, and the minimum value determined for each year. The series of annual minimum mean 7-day flows are fit to a theoretical frequency distribution, and the flow magnitude that is expected to not be exceeded, on average, once in 10 years is the $7 \mathrm{Q}_{10}$ low-flow statistic. The annual nonexceedance probability, $\mathrm{p}$, of the low-flow statistic is the inverse of the expected recurrence interval, $1 / \mathrm{T}$, or $1 / 10=0.1$, for $7 Q_{10}$. The recurrence interval is an estimated period, averaged over a very long period of time, and it is not a prediction of when a particular flow will happen. For example, the $7 Q_{10}$ flow could happen 3 years in a row, and it may not recur during any given 20 -year period. 
Resources limit the routine collection of flow data on every stream reach and at every stream site where such information eventually may be needed. Therefore, methods of estimating low-flow frequency statistics by use of regionalregression equations have been developed, and these methods effectively transfer information from gaged to ungaged stream sites. The estimating methods presented in this report apply only to stream sites where low flows are not appreciably affected by drainage-basin modifications such as regulation by reservoirs, interbasin transfers, withdrawals, and discharges.

\section{Purpose and Scope}

This report presents estimates of, and methods for estimating, selected low-flow frequency statistics $\left(30 \mathrm{Q}_{2}, 30 \mathrm{Q}_{5}\right.$, $7 Q_{2}, 7 Q_{10}$, and $7 Q_{20}$ ) for streams in Kentucky. The report describes the methods used for estimating these statistics at 121 gaged stream sites where a range of streamflow information has been collected through climate year 2006. The report also describes the development, accuracy, limitations, and application of methods to estimate these statistics at ungaged, unregulated stream sites where flows are not appreciably affected by local diversions.

\section{Previous Studies}

Previous studies have presented selected low-flow frequency statistics estimated from USGS streamflow-gaging data in tabular and map formats including Speer and others, 1965; Swisshelm, 1974; Davis, 1979; Sullavan, 1980, 1984; Melcher and Ruhl, 1984; and the Ohio River Valley Water Sanitation Commission, 2006. Ruhl and Martin, 1991, presented statewide regression equations for estimating selected low-flow frequency statistics.

\section{Description of Study Area}

The Commonwealth of Kentucky is an area of 40,395 $\mathrm{mi}^{2}$ in the east-central United States. The major drainage basins in Kentucky-Big Sandy, Licking, Kentucky, Lower Ohio-Salt, Upper and Lower Cumberland, Green, and Lower Tennessee Rivers - are tributaries to the Ohio River, the northern border of Kentucky adjacent to Ohio, Indiana, and Illinois and the Mississippi River on the western border of Kentucky adjacent to Missouri (fig. 1). In a generalized annual water balance for Kentucky, about 60 percent of precipitation leaves drainage basins as evapotranspiration and about 40 percent leaves as direct runoff and (or) the shallow groundwater flow that produces the seasonal low flows in late summer and early autumn (September-October). The hydrologic conditions that determine low-flow characteristics vary widely across geographic and time scales in Kentucky as described in this report.

\section{Geology and Physiography}

Topographic relief in Kentucky reflects the results of long-term stream-erosional processes in relation to the rock formations. The upland areas - hills, ridges, mountains, and plateaus - generally consist of formations resistant to erosion. Western and central parts of Kentucky have rolling terrain, whereas, the eastern part of Kentucky has rugged terrain with high relief. Land-surface elevations (the distance above the vertical datum) in Kentucky vary by more than $3,500 \mathrm{ft}$ and range from $260 \mathrm{ft}$ above the National Geodetic Vertical Datum of 1929 (NGVD 1929) along the Mississippi River to 4,145 ft at the peak of Black Mountain in Harlan County near the Kentucky-Virginia border (McGrain and Currens, 1978).

The physiography of the State reflects the lithology of the surface rocks and largely is defined by the Cincinnati Arch (fig. 2). The axis of the Cincinnati Arch trends northward from south-central Kentucky to just south of the Outer Bluegrass boundary where the axis divides into two branches-Kankakee (the northwestward branch) and Findlay Arches. The branches are almost parallel but are separated by about $25 \mathrm{mi}$ at the Ohio River (McFarland, 1950). Lithologic units dip away from the axis of the arch — a regional structural high — so that geologic features generally are symmetrical on each side of the arch.

Progressively younger rocks are exposed at the surface east and west of the Cincinnati Arch (fig. 2). The oldest exposed rocks are part of the Jessamine Dome and adjacent areas; this area corresponds approximately to the Inner Bluegrass region. These rocks consist of limestone, shale, and sandstone of Ordovician age (fig. 3). Narrow bands of shales and limestones of Silurian and Devonian age surround this area and correspond to The Knobs region. An expansive area of limestone of Mississippian age (Mississippian Plateaus Region) is exposed starting at the Ohio River in northeastern Kentucky, extending southwest to the State boundary, and extending northwest in a crescent-shaped area surrounding the Western Kentucky Coal Field. The eastern boundary of this area is the Cumberland Escarpment. Sandstones, shales, siltstones, and coals of Pennsylvanian age in eastern and northwestern Kentucky - the youngest rocks in Kentucky — compose the Eastern and Western Kentucky Coal Fields. Alluvial deposits of Cretaceous and Tertiary age are in extreme western Kentucky in the Mississippi Embayment.

Much of the Mississippian Plateaus is characterized by carbonate rock and karst features such as sinkholes, caves, springs, and losing streams. Most well-developed karst features are in a band originating in west-central Kentucky and extending to south-central Kentucky, southeast to the State boundary, east along the boundary, and then northeast and north. Less-well-developed karst features are in central and south-central Kentucky. Detailed descriptions and maps illustrating the geology and physiography of Kentucky are presented in The Geology of Kentucky (McDowell, 1986). 


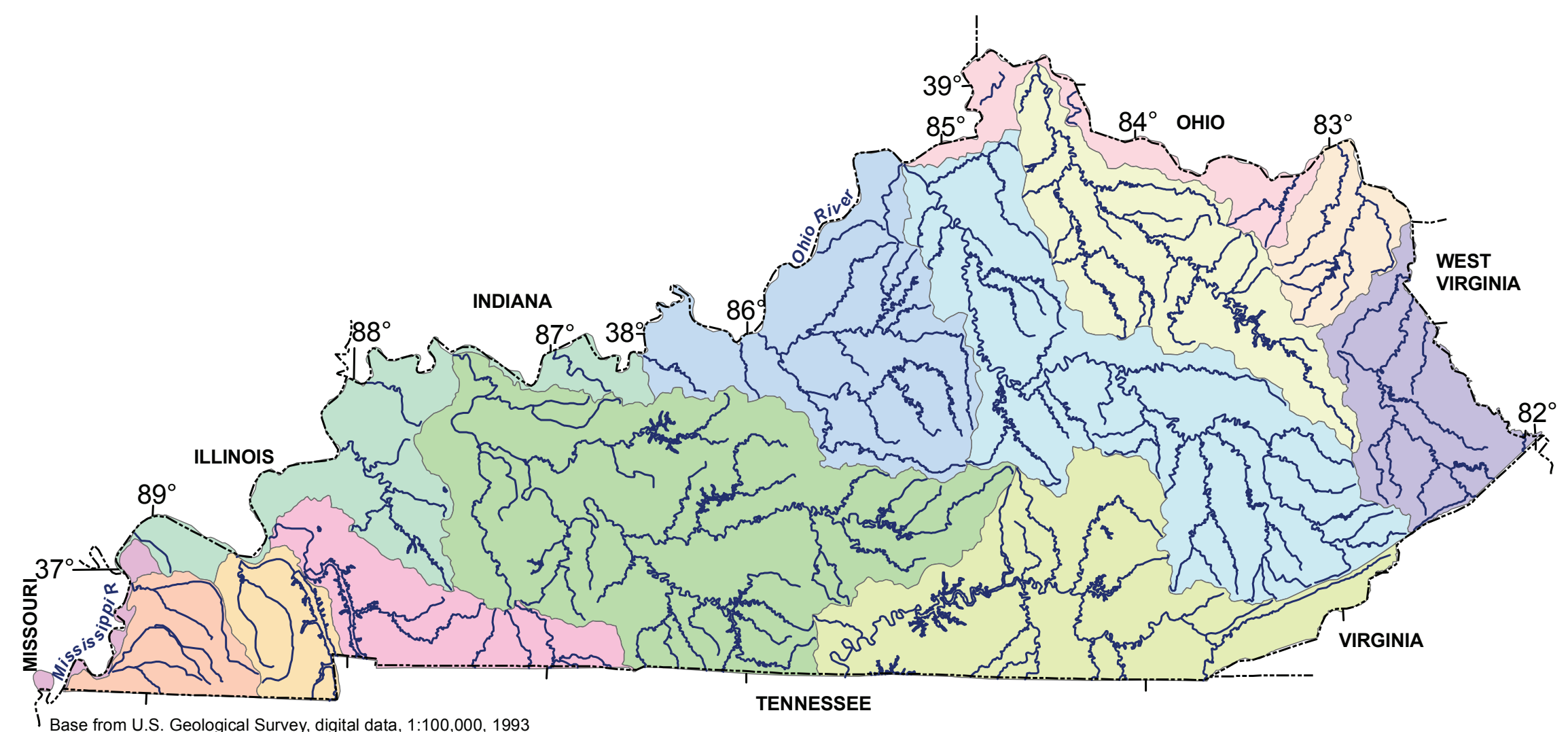

Base from U.S. Geological Survey, digital data, 1:100,000, 1993
Lambert conformal conic projection, North American Datum 1983

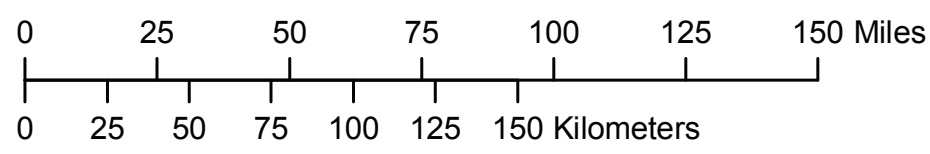

\section{EXPLANATION}

\begin{tabular}{l|l|l|l|}
\hline & BIG SANDY & LOWER OHIO - SALT & UPPER CUMBERLAND \\
\hline GREEN & LICKING & LOWER TENNESSEE \\
\hline HATCHIE - OBION & LOWER CUMBERLAND & LOWER MISSISSIPPI - MEMPHIS $\square$ \\
\hline KENTUCKY & MIDDLE OHIO - LITTLE MIAMI \\
\hline$\square$ & LOWER OHIO & MIDDLE OHIO - RACOON
\end{tabular}

Figure 1. Major drainage basins in Kentucky. 


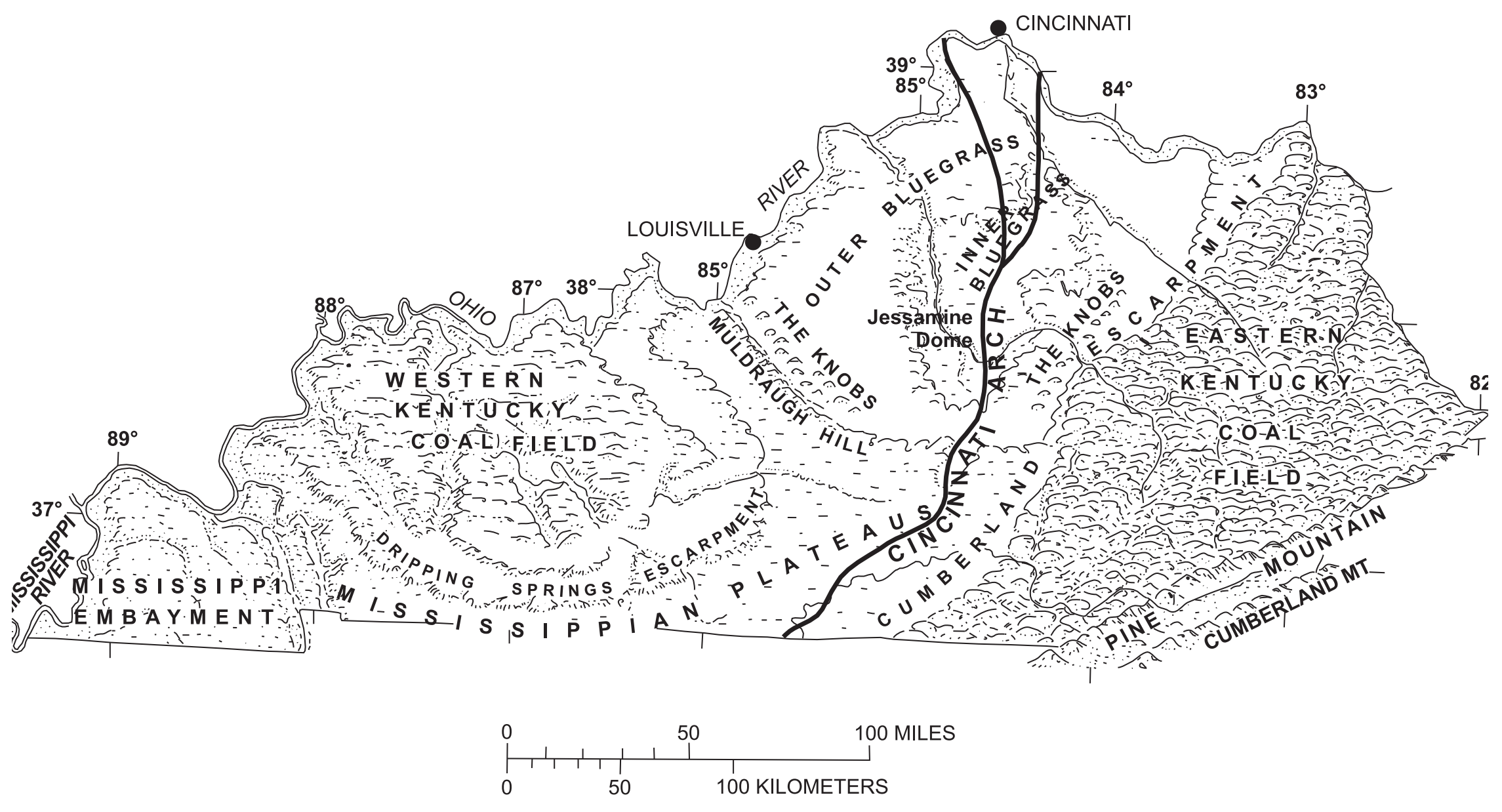

Figure 2. Physiographic regions in Kentucky [from Kentucky Geological Survey, 1980]. 


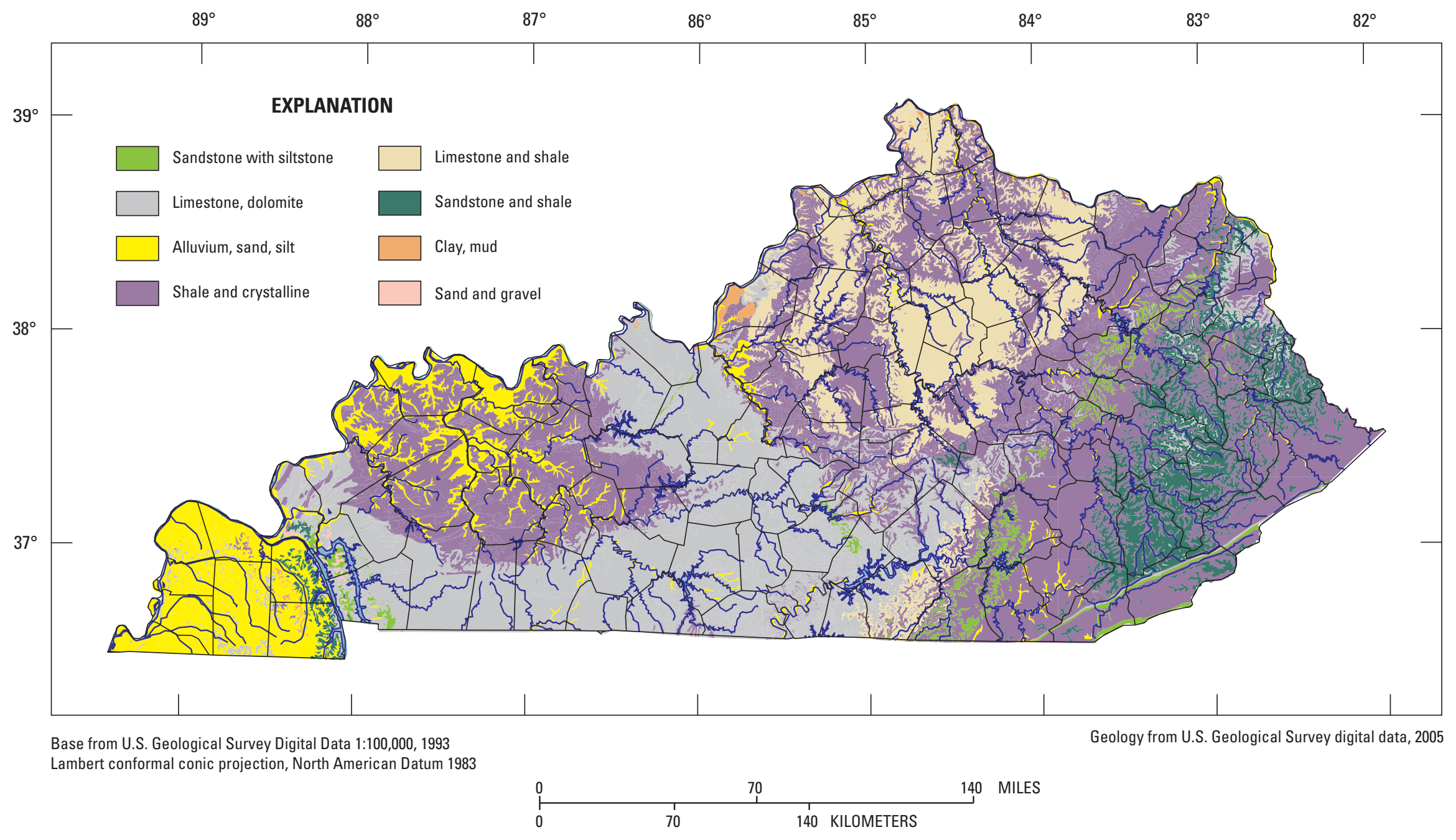

Figure 3. Generalized geology of Kentucky. 


\section{Climate}

Kentucky has a moist-continental climate with distinct seasonal variations and highly changeable weather patterns. Weather patterns in Kentucky are affected variably by the meeting of cold, continental air masses arriving from the northwest and warm, moist air masses moving up the Mississippi and Ohio River Valleys from the southwest (Conner, 1982). Temperatures and precipitation vary from southwest to northeast under the influence of latitude and elevation (Hill, 2005).

Winter temperatures are moderate, rarely below $0^{\circ} \mathrm{F}$; typical summer temperatures are warm, humid, and occasionally more than $100^{\circ} \mathrm{F}$. Average annual snowfall varies from about $10 \mathrm{in}$. in the southwest to about $20 \mathrm{in}$. in the northeast. Snow cover rarely persists longer than 1 week in the southwest and 2 weeks in the northeast. Normal mean annual temperature (1971-2000) varies from $59^{\circ} \mathrm{F}$. in the southwest to $53^{\circ} \mathrm{F}$. in the northeast. Most areas of Kentucky receive about 40 percent of available sunshine in winter and about 60 percent of available sunshine in summer because of clouds (Kentucky Climate Center at Western Kentucky University, 2010).

Annual precipitation in Kentucky averaged about 50 in. at 29 long-term reporting stations for the period 1971-2000. The distribution of precipitation varies areally, annually, and seasonally. The normal mean annual precipitation in Kentucky ranges areally from about $55 \mathrm{in}$. in the southwest to $43 \mathrm{in}$. in the northeast (Hill, 2005). Rainfall generally decreases to the north, reflecting the increase in distance from the source of moisture, which primarily is the subtropical Atlantic Ocean and Gulf of Mexico. Kentucky has considerable year-to-year variation in precipitation. For example, during the period 1951-80, annual precipitation at reporting stations ranged from 14.5 to 78.6 in. Large amounts of precipitation in Kentucky have been associated with tropical cyclones moving north from the Gulf of Mexico (Conner, 1982).

Precipitation falls throughout the year but the sources and amounts of precipitation vary seasonally. Although March generally is the wettest month of the year, averaging from 4 to 6 in., the precipitation pattern is bimodal with a second peak, averaging from 3.3 to 5.5 in., in July. October generally is the driest month when precipitation averages from 2 to 3 in. Mean seasonal precipitation in Kentucky is about 13.5 in. in spring (March through May), 12.4 in. in summer (June through August), 9.8 in. in autumn (September through November), and 11.5 in. in winter (December through February) (Conner, 1982).

Winter precipitation is characterized by frontal storms. Summer precipitation generally results from thunderstorms. Precipitation intensity generally is higher in summer than during other seasons, but the number of days having precipitation is similar in winter and summer. The Bermuda highpressure system has a strong effect on seasonal precipitation patterns in Kentucky. In the autumn, this high-pressure system generally moves inland from the southeastern coast of the United States and is centered over Kentucky and Tennessee, where this system inhibits convective activity and frontal storm movement and produces a dry season (Conner, 1982).

Daily average temperature and total precipitation data for the 110-year period January 1895-December 2004 (Kentucky Climate Center at Western Kentucky University, 2008a, 2008b), aggregated to monthly and annual values, were examined to assess how seasonal weather and longterm climate patterns (the climate signal) may have affected low-flow characteristics in Kentucky. These annual data were plotted with locally weighted scatterplot smooth (LOWESS) curves (Cleveland 1979, 1984; Helsel and Hirsch, 2002) fitted to identify general patterns in the data over time (fig. 4). The LOWESS curve shows temperatures generally increased from around 1900 until 1945, then decreased until about 1975, then increased to the end of the available record in 2004. These temperature patterns are consistent with those patterns reported for global mean surface temperature for these periods (National Research Council, 2006). Precipitation in Kentucky has generally had an positive trend during the period 1895 2004 , except during a flat to declining period from the 1930s into the 1950s. This overall precipitation increase in Kentucky from 1895-2004 is consistent with reported increases over land areas north of 30 degrees north latitude (Karl and others, 1996; Karl and Knight, 1998; Solomon and others, 2007).

Multiple statistical trend tests were made by use of the daily temperature and precipitation data aggregated to monthly and annual values (appendix 1). The results were, in general, consistent with the patterns observed in the LOWESS curves (fig. 4), though no full-year trend in temperature during the entire 1895-2004 period was detected. A notable positive trend in the statewide monthly cold-season (November-March) temperatures and negative trend in warm-season (April-October) temperatures was observed from 1895-2004. The warm-season precipitation can be intense (as is typical in the summer months) and generally contributes proportionately more to direct-runoff surface-water flows and less to groundwater recharge than happens during other periods of the year. The warm-season precipitation had positive trend from 1895-2004. However, only one of the tests indicated a positive trend for full-year monthly precipitation for the period 1895-2004. The historical relations of temperature, precipitation, and low-flow characteristics in Kentucky are explored further in the section "Assessment of the Annual Low-Flow Time-Series Data.” 

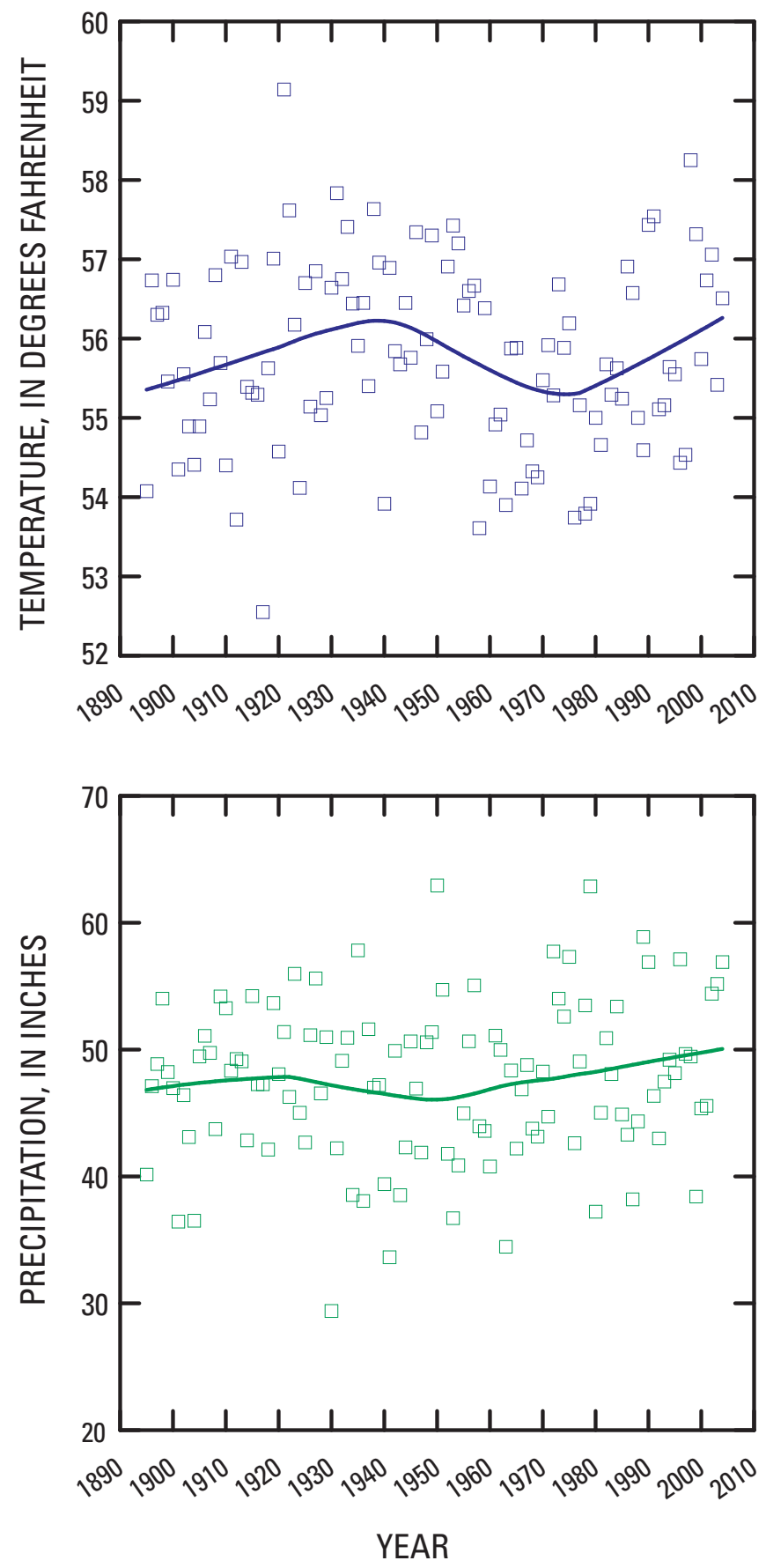

Figure 4. Annual temperature and precipitation with a LOWESS curve fit to the data for the period 1890-2004 in Kentucky.

\section{Methods for Data-Collection Stations}

Low-flow frequency statistics were estimated at streamflow-gaging stations by methods that varied with the type and amount of streamflow data that were available. The statistics were estimated by fit of the annual low-flow time series to a theoretical frequency distribution at the long-term, continuousrecord (LTCR) streamflow-gaging stations, which typically by definition have daily mean discharge records available for 10 or more years. The statistics were estimated by methods of correlation to the LTCR (index) stations at the low-flow, partial-record (LFPR) streamflow-gaging stations, which typically have a few instantaneous streamflow measurements during representative base-flow periods. LTCR stations having less than 10 years of data also were treated as LFPR stations.

\section{Long-Term Continuous-Record Streamflow- Gaging Stations}

Available daily mean streamflow data were retrieved by use of the USGS National Water Information System (NWIS) Automated Data Processing System (U.S. Geological Survey, 2003) and the NWIS online database (http://waterdata. usgs.gov/nwis). The USGS has collected continuous-record streamflow-gaging information in Kentucky since 1907 (Beaber, 1970); other agencies have collected such data in Kentucky beginning in 1890. The data were checked and verified by comparison of summary statistics for the published data (Wells, 1957, 1958; Hendricks, 1964; U.S. Geological Survey, 1964, 1962-65, 1966-75, and 1976-2007). Lowflow frequencies were estimated for LTCR stations by use of annual-minimum-mean flows for $\mathrm{D}$ consecutive days (D-day low flows where $\mathrm{D}=1-365$ ). The $\mathrm{D}$-day mean flows (for 7 and 30 consecutive days in this study) were computed for the entire period of record and the minimum value was selected for each year. The annual period used was the climate year, which extends from April 1-March 31, because this period typically encompasses the late summer and early autumn period when most streams in the United States reach an annual minimum flow. In this report, the climate year is referenced by the year in which the 12-month period ends. The base-10 logarithm of the annual D-day low flows were fit to the widely used Pearson Type III theoretical three-parameter frequency distribution and plotted along with the "graphical fit" defined by the Weibull plotting-position formula

$$
p=m / n+1
$$

where

$$
\begin{gathered}
p \quad \text { is the nonexceedance probability, } \\
m \quad \text { is the order number of the D-day annual low- } \\
\text { flow value after ranking from smallest to } \\
\text { the largest magnitude, and }
\end{gathered}
$$


The graphical fit is considered the basic frequency curve for annual low flows; however, a purely statistical analysis may provide misleading results and final interpretation on the adequacy of the frequency curves is based on the professional judgment of the hydrologist (Riggs, 1972). The log-Pearson Type III frequency distribution fit is a function of the mean, standard deviation, and skew of the log-transformed annual D-day low-flow series. Other frequency distributions also have been found to perform adequately (Tasker, 1987; Vogel and Kroll, 1989).

Several of the LTCR stations in Kentucky have one or more annual D-day low-flow time-series values equal to zero, which cannot be log-transformed. (Occasionally, all the annual D-day low flows were zero; therefore, the statistic was zero for all recurrence intervals.) A conditional probability adjustment was made for the time series having some zeros on the basis of the mean, standard deviation, and skewness of the nonzero annual values (Interagency Advisory Committee on Water Data, 1982; Tasker, 1987).

The frequency analysis was done for 102 unregulated LTCR stations in Kentucky (those stations where annual lows were suitable for frequency analysis and were used in the regression analysis) with data through the 2006 climate year by use of the USGS program, SWSTAT (Lumb and others, 1990). Descriptions of these stations are in table 1 (at back of report), and the estimated low-flow frequencies are in table 2 (at back of report). Station locations used in the analyses are shown in plate 1 .

Details concerning the review, analysis, and screening of the annual low-flow time-series data at the LTCR stations prior to frequency analysis, the treatment of trended annual lowflow data, and combining data at nearby LTCR stations are in the following sections of this report.

\section{Assessment of the Annual Low-Flow Time-Series Data}

The results of frequency analysis may be adversely affected if the annual low-flow time-series data are not random, independent, and stationary over time, as is assumed. A homogeneous, systematic annual low-flow time series that has unchanging statistical properties and is representative of the same population of annual low flows is ideal. Therefore, the annual 7- and 30-day low-flow data (and in addition 1and 90-day lows) were closely examined for possible trends and any indications of regulation, local diversions of flow (discharges and withdrawals), and possible sustained changes in streamflows because of changes in the prevailing climate (Lins and Slack, 1999; McCabe and Wolock, 2002). The data-screening procedures required consideration of multiple lines of information to make a judgment as to the suitability of specific periods of the annual low-flow data for frequency analysis. The components of the data-screening procedures included (1) careful visual screening and comparison of time-series and other plots of the data, (2) analysis of available water withdrawal and discharge permit information, and (3) statistical trend tests.

Variations in meteorological and climate conditions were indicated in selected short-term periods of record (for less than about 4-5 decades) (see "Climate" section). For example, the LOWESS curves and trend tests indicated temperatures increased for the period 1895-1945, decreased 1946-75, and increased again 1976-2004 (appendix 1). However, a statistically significant year-round temperature trend with longterm persistence was not demonstrated. The warm-season (April-October) precipitation did have a positive trend from 1895-2004, which might tend to divert potential groundwater recharge water to direct runoff in surface waters, thus possibly diminishing base flows. However, only one of the tests (seasonal-Kendall of monthly data) indicated a positive trend (p-value 0.0835) for full-year precipitation for the period 1895-2004. Given these inconclusive results of trend tests for the precipitation data and the lack of a demonstrated long-term trend in the temperature, the periods of annual low-flow record having short-term fluctuations or trends were retained and provided data representative of the full range of climate conditions observed during the period of record. The data were not detrended to address such fluctuations in climate conditions absent a long-term, persistent trend in the annual low flows (Julie Kiang, U.S. Geological Survey, oral commun., 2008).

The potential effects of local diversions of flow on lowflow characteristics at each gaging station also were assessed by analysis of available statewide permit information for local diversions of flow. A geographic information system (GIS) to compile and account for withdrawals and discharges in basins upstream from the low-flow stations was developed. KDOW wastewater-discharge-permit data (Kentucky Pollution Discharge Elimination System (KPDES), Vickie Prather, written commun., 2007) for 1989-2004 and water-withdrawal data for 2002-05 (Downs and Caldwell, 2007) were compiled and analyzed. The KPDES data include 2,770 discharge sources (after excluding the "stormwater" waste code). An inventory of withdrawals and discharges was made for each low-flow station along with a statewide GIS. A full, rigorous statewide mathematical water balance of the cumulative water withdrawals and discharges data was not feasible because of data limitations, and the need to address these data needs was beyond the scope of this study. Instead, a simple accounting of the numbers of permitted withdrawals and discharges by gaging station was prepared (table 1) and considered in screening the annual low-flow times-series data for the possible effects of local diversions. About 50 percent of LTCR and LFPR stations had at least one local diversion upstream according to the GIS inventory developed from the permit data. 
The annual 7-day low-flow time series was examined for various periods for each station record by use of two trendscreening tests, one of which compensated for serial correlation of the data, as described in appendix 2. These two trend tests were used as data-screening tools and were considered along with the other information on permitted withdrawals and discharges and indications in extensive data plots as to the suitability of the annual low-flow data for frequency analysis as described.

The annual low-flow times-series plots for all LTCR stations in Kentucky were examined and compared to each other and to plots of selected LTCR stations in the HydroClimate Data Network (HCDN) (Slack and Landwehr, 1992) and Hydrologic Benchmark Network (HBN) (Mast and Turk, 1999) in Kentucky and nearby States. Many, but not all, of the HCDN and HBN stations have a low-flow regime unaffected by regulation and (or) local diversions of flows. Time-series plots and LOWESS curves fit to annual low flows at Twin Creek near Germantown, Ohio, (03272000); Little Wabash River below Clay City, Illinois, (03379500,); French Broad River at Ashville, North Carolina, (03451500,); Clinch River above Tazewell, Tennessee, (03528000); Tellico River at Tellico Plains, Tennessee, (03518500); Greenbrier River at Alderson, West Virginia, (03183500); Nolichucky River at Embreeville, Tennessee, (03465500); Powell River near Jonesville, Virginia, (03531500) in (or subbasins of) the HCDN, and Holiday Creek near Andersonville, Virginia, (02038850); Upper Twin Creek at McGaw, Ohio, (03237280); Cataloochee Creek near Cataloochee, North Carolina, (03460000); Little River above Townsend, Tennessee, (03497300); North Sylamore Creek near Fifty Six, Arkansas, (07060710) in (or subbasins of the HBN, among other stations, were reviewed (appendix 3).

Unusually large annual low flows were observed at several gaging stations in Kentucky in selected years, including the 1916, 1929, 1943, 1951, 1959, 1961, 1972, 1975, 1980, 1986, 1990, and 1997 climate years. A comparison of the annual low flows among nearby gaging stations confirmed the magnitude of the unusually large low flows, and these flows were attributed to unusually wet conditions in certain parts of the State at that time. These occasional, unusually large annual low flows were considered part of the variations in regional meteorological conditions, and all such data were retained in the frequency analysis.

The annual low-flow time-series plots and LOWESS curves for most of the HCDN and HBN stations with unregulated, unmodified drainage basins in Kentucky and surrounding States showed common patterns of increasing and decreasing annual low flows. These flow patterns include the apparently climate-related decrease (or 'dip') in low flows for the 1920-1950s period, which was concurrent with a period of increasing temperature and generally steady to declining precipitation; a step-trend increase - a concave-downward 'bump' in low flow during the wet, cool 1970s; and generally a negative trend in low flows since then (fig. 5). Only a few stations had LOWESS curves of the low-flow time-series data that remained almost constant during the 1980-2006 period. This pattern of decreasing then increasing and then again decreasing annual low flows during the 1920-2006 period, a sinusoidal-wave form, was deemed the characteristic shape (an "s-curve") representative of changes in the annual low-flow time series that resulted only from the changes in meteorological and climate conditions in Kentucky during this period. This characteristic s-curve shape of the annual low flows was judged representative of the regional 'climate signal,' and indicative of stationary, homogeneous, streamflow in basins having no substantial anthropogenic basin modifications (regulation or local diversions). Even several highly trended annual low-flow time series LOWESS curves showed the same s-curve, climate-signal pattern superimposed in the overall trend.

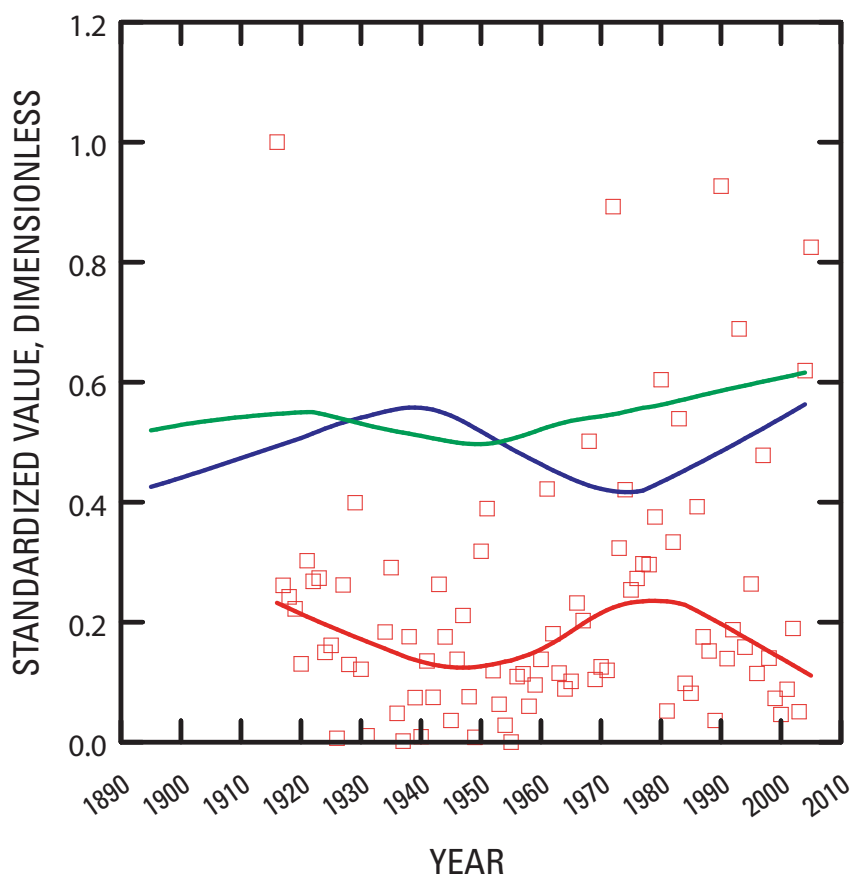

\section{EXPLANATION}

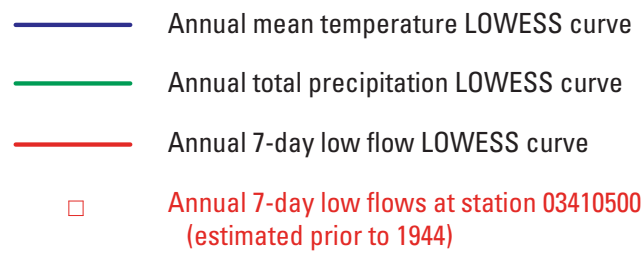

Figure 5. LOWESS curves fit to the standardized Kentucky annual mean temperature, total precipitation, and 7-day low flows at South Fork Cumberland River near Stearns, Kentucky (station number 03410500). 


\section{Methods for Estimating Selected Low-Flow Frequency Statistics for Unregulated Streams in Kentucky}

The curves for station South Fork Cumberland River near Stearns, Kentucky, (number 03410500, table 1, fig. 5) had the characteristic s-curve pattern in the annual low flows that was considered representative of homogeneous, unmodified basins only affected by meteorological and climatic patterns (the climate signal) during the entire period of record. The station near Stearns, with a sparsely populated drainage area of $954 \mathrm{mi}^{2}$ in mountainous northeastern Tennessee and southeastern Kentucky and about 94 percent forested, appeared largely unaffected by the other potential anthropogenic basin modifications such as land and water-use changes ( 4.4 percent pasture and other grasses, 0.6 percent residential and commercial, 0.1 percent quarries and strip mines, and 0.1 percent open water) (Tennessee Department of Environment and Conservation, 2007) that could potentially alter the low-flow regime. This station was selected as a reference station for comparison to the annual low-flow data at all LTCR stations in Kentucky.

Double-mass curves (Searcy and others, 1960; fig. 6) were developed for comparison of cumulative annual 1-, 7-, 30-, and 90-day low flows at each LTCR station in Kentucky and at the reference station at Stearns, Ky., station number 03410500. A uniform, constant slope in a double-mass curve indicates no change in the relation between the paired time series. A change or 'break' in the slope of the double-mass curve indicates that the relation between the time series has

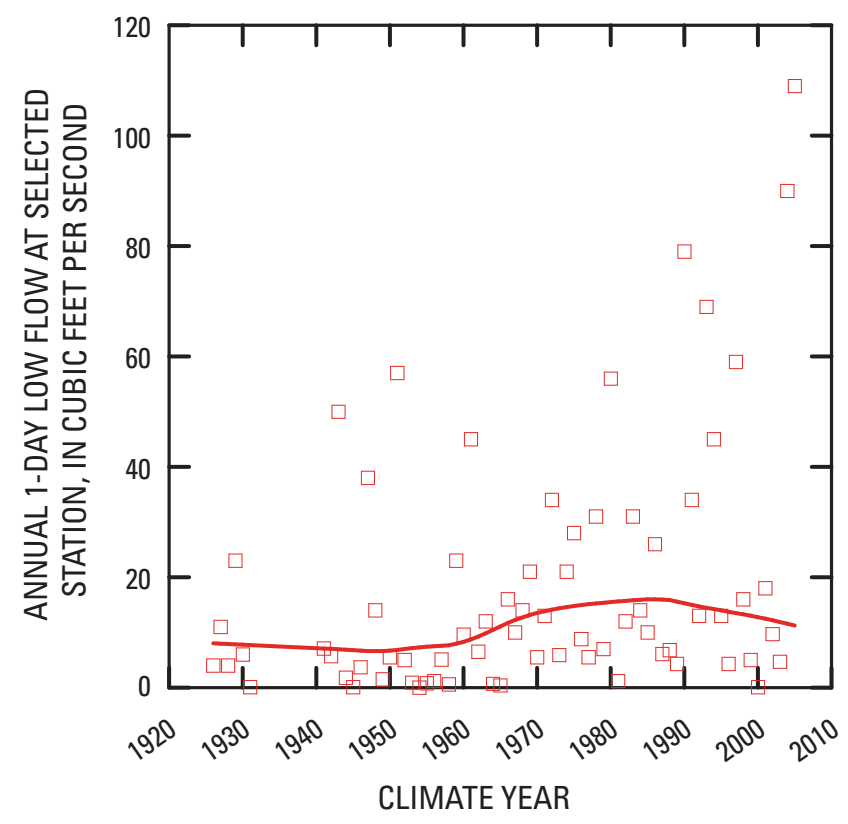

changed for some reason. The most common cause for a change of slope of double-mass curves of the annual D-day low flows is a basin modification such as regulation or local diversions - water withdrawals and discharges - that have changed the low-flow regime in one (or both) of the basins.

The homogeneous periods of annual low-flow record (table 1), generally in the early part of record before basin modifications, were identified primarily from the uniform, linear periods of record of constant slope on the double-mass curves - by a visual examination of the annual low-flow time-series plot with the LOWESS curve and the double-mass curve paired with the reference station at Stearns, Ky.- - while also considering the inventory of permitted local diversions upstream from each station and results of the trend-screening tests (appendix 2).

Use and interpretation of the double-mass curves are not without limitations. Some deviations or breaks in double-mass curves were observed when comparing the reference station to other LTCR stations in Kentucky having small basins (less than $100 \mathrm{mi}^{2}$ ) where localized meteorological and climate conditions likely contributed to the difference, because other nearby stations, when available, generally had a pattern of annual low flows similar to that observed for the small drainage basin.

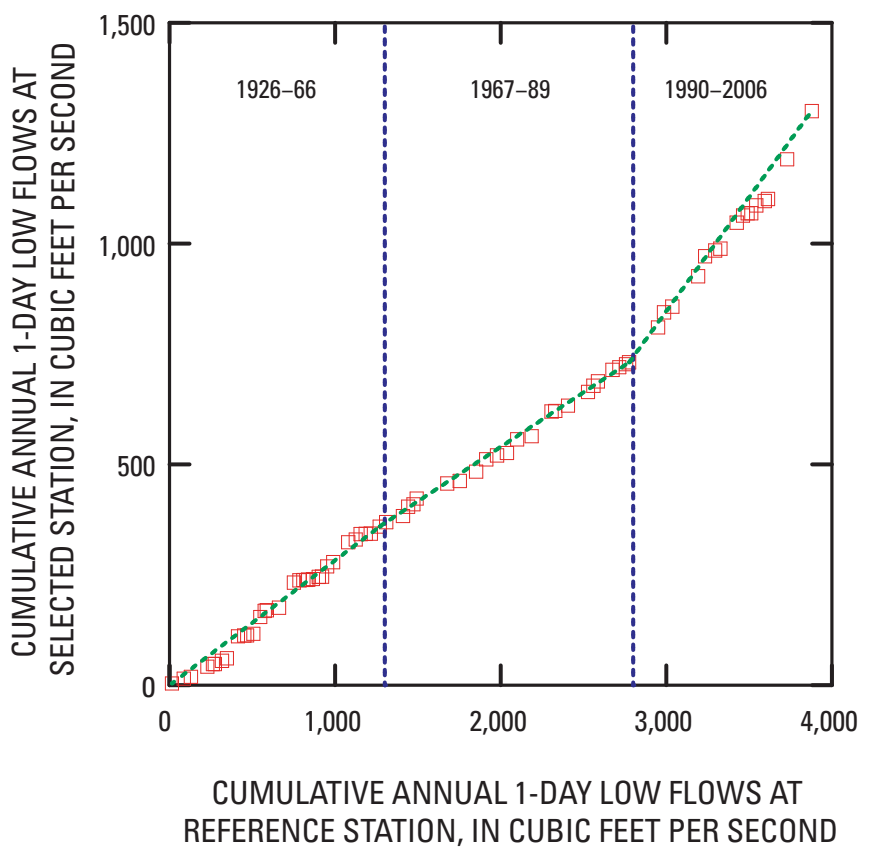

Figure 6. Annual mean 1-day low flows, LOWESS curve fit to low flows at station South Fork Kentucky River at Booneville, Kentucky (03281500), and double-mass curve comparing cumulative annual 1-day mean low flows at the selected station and the reference station South Fork Cumberland River near Stearns, Kentucky (03410500), showing three periods of homogeneous low flows during 1926-60, 1967-89, and 1990-2006. 
Similarly, but at a larger regional scale, some breaks in slope around 1960 (and occasionally around 1970 for stations to the south of Kentucky), possibly related to a shift in the regional climate, was noted in many but not all double-mass curves created for the HCDN and HBN stations that used the selected reference station at Stearns, Ky. Double-mass curves of annual low flows at selected HCDN and HBN stations are described further in appendix 3 . The double-mass curves of annual low flows at the HCDN and HBN stations listed previously with homogeneous records and unmodified basins when paired with the annual low flows at the reference station at Stearns, Ky., generally had a uniform linear pattern, which was indicative of little, if any, change in the relation of the concurrent annual low flows. Generally a uniform slope was evident before and after the break when the change in slope occurred around 1960. These changes in slope of the doublemass curves were judged a regional phenomenon, possibly climate-related, that caused little if any effect on the definitions of the homogeneous periods of low-flow record suitable for frequency analysis (table 1 and appendix 3).

The local diversion records also had limitations in completeness and accuracy in some cases. For example, agricultural water withdrawals in Kentucky are commonly needed in dry periods and were not subject to withdrawal-permit requirements. Therefore, some low-flow data possibly affected by local diversions of flow may be included in periods identified as having homogeneous, stationary, unregulated-flow conditions; however, such effects were likely minor during these periods identified as homogeneous.

Selected stations with pronounced trends in annual low flows likely caused by local diversions of flow and (or) basin modifications were identified also (table 1 and appendix 2). An approach for detrending such annual low-flow time series is presented in appendix 4. However, no low-flow frequency statistics derived from detrended annual low-flow series were used in the final regressions because of the uncertain error characteristics for these stations with trended annual low flows. Further investigation is warranted concerning (1) estimation low-flow frequency statistics for trended annual low flows by use of a detrending procedure, such as described in appendix 4, and (2) identification of homogeneous, postbasin-modification or regulated periods of record suitable for frequency analysis by use of double-mass curves.

\section{Combining Low-Flow Streamflow-Gaging-Station Records}

The daily mean discharge records at two pairs of LTCR stations located near each other on the same stream were combined to provide extended periods of record. The simple drainage-area-ratio method was used to estimate discharge at one of the paired stations because the drainage areas of these two pairs of stations differed by about 5 percent. The estimated and combined records were treated as single discharge records representative of long-term flows at one of the paired adjacent gages. Records at stations Kinniconick Creek near Tannery, Kentucky, (03237250) and Kinniconick Creek below Trace
Creek at Tannery, Kentucky, (03237255), (tables 1 and 2) were combined by adjusting the discharge record for the period October 1, 1991, until December 7, 2000, at upstream station 03237250 by the ratio of the drainage areas at the two stations (1.065), which provided a combined record spanning water years (the 12-month period ending September 30 of each year) 1992-2006 (climate years 1993-2006) for station 03237255. Records at station Cumberland River at Pine Street Bridge at Pineville, Kentucky, (03402900) and Cumberland River near Pineville, Kentucky (03403000) were combined by multiplying the discharge record for the period October 1, 1991-September 30, 2005, at upstream station 03402900 by the ratio of the drainage areas at the two stations (1.051), which provided a combined record spanning water years 1939-2005 (climate years 1940-2005) for station 03403000.

\section{Low-Flow Partial-Record Streamflow-Gaging Stations}

Estimates of low-flow frequencies at LFPR stations can be made by use of either graphical or mathematical correlation methods. Estimates in this report were made by use of the mathematical correlation method of Stedinger and Thomas (1985). Estimates for the LFPR stations included in the weighted-least squares (WLS) regressions are shown in table 2.

\section{Methods for Ungaged Stream Sites}

The collection data for all streams where low-flowfrequency estimates may be needed is not feasible. Therefore, low-flow regionalization methods to transfer information from gaged to ungaged sites have been developed as described in following sections.

\section{Regional-Regression Method}

Regionalization of the low-flow statistics was accomplished by development of statistical regression models of two types-logistic regression and multiple-linear regression. These regressions relate low-flow characteristics (dependent or response variable) to selected basin characteristics (independent or explanatory variables), which are shown in table 3 (at back of report). Many streams in Kentucky have an annual minimum low flow of zero. The annual probabilities of the 7and 30-day low flows being equal to zero were regionalized by use of logistic regression. The nonzero values of the low-flow statistics $\left(30 \mathrm{Q}_{2}, 30 \mathrm{Q}_{5}, 7 \mathrm{Q}_{2}, 7 \mathrm{Q}_{10}\right.$, and $\left.7 \mathrm{Q}_{20}\right)$ were regionalized by use of multiple linear regression, including ordinary-leastsquares (OLS) and WLS regressions. Application of these regression models is a sequential process that begins with estimation of the probability of the selected low-flow statistic being equal to zero by use of the logistic-regression equations. Nonzero low-flow statistics are estimated by use of the final WLS-regression equations. Development and application of these regression equations is described in the following sections of this report. 


\section{Basin Characteristics}

Various drainage-basin characteristics were tested for applicability in the regionalization process. Selection of basin characteristics for inclusion in exploratory scatterplots, linearcorrelation analysis, the logistic-regression analysis, and the subsequent multiple-linear-regression analysis was based on (1) the possible hydrologic importance of the characteristic in relation to the low-flow frequencies, (2) the ability to measure the characteristics, and (3) results of previous regionalization studies of the same and other similar streamflow statistics (Beaber, 1970; Thomas and Benson, 1970; Wetzel and Bettandorff, 1986; Choquette, 1988; Ruhl and Martin, 1991; Martin and Ruhl, 1993; and Martin, 2002).

All low-flow frequencies (dependent variable) and the basin characteristics (independent or explanatory variables) were $\log -10$ transformed to a linear relation. Basin characteristics expressed as a percentage had a one added to allow the log transform.

All map-based basin characteristics (table 3) were measured from digital coverages by use of ARC/INFO, ArcGIS, and ArcHydro Tools available in ArcGIS version 9.0. The name, units, method of measurement, and source data for the basin characteristics tested in the regression analyses are in table 3. Values of the basin characteristics used to develop the final regional regression equations, the total drainage area and mapped streamflow-variability index, are listed in table 2 .

The streamflow-variability index (V) (Lane and Lei, 1950 ) at a streamflow-gaging station ("station" value) is computed as the standard deviation of the base-10 logarithms of the 19 flow values at 5-percent class intervals from 5 to 95 percent on the flow-duration (cumulative-frequency) curve (Searcy, 1959; SAS Institute, Inc., 2004) of daily mean streamflow for the identified homogeneous periods of record (table 2). The $\mathrm{V}$ values used in this study were updated from the values used in the previous study (Ruhl and Martin, 1991; Martin and Ruhl, 1993) on the basis of (1) the defined homogeneous periods of flow and (2) computation by use of the 19 designated 5-percentile-point increments selected from the flow-duration curve defined by a continuous ranking of the daily mean streamflow values for the complete water years of data in the homogeneous period of record. Initial values of $\mathrm{V}$ in this study were computed by excluding the zero-flow points (which cannot be log-transformed) on the low-flow end of the flow-duration curves. (For example, the 95-percent duration flow, at which 95 percent of all daily mean streamflow is greater than or equal to the indicated flow, is at the low-flow end of the flow-duration curve.) However, these initial V values differed substantially from the values computed previously when comparing the same station and period of record (Ruhl and Martin, 1991). When, instead of excluding the zero-flow points, a value of 0.005 was substituted for the zeros allowing all 19 5-percentile points to be included, results closely compared with previously computed values. This substitution captures the full range of the flow-duration curve, which was missed when the zero points on the curve were excluded. The substitution of $0.005 \mathrm{ft}^{3} / \mathrm{s}$ for zeros approximates the shape of the flow-duration curve as developed in the algorithm used in the previous Kentucky low-flow study (Searcy, 1959; Dempster, 1990), which defined 20 to 30 class intervals along the flow-duration curve and generated a series of small, nonzero flows at the low end of the flow-duration curve.

A characteristic related to $\mathrm{V}$ is the flow-duration ratio, which is computed as the ratio of selected values on the flowduration curve. The ratio of the 20-percent flow duration to the 90-percent flow duration (R2090) was computed for comparison to the $\mathrm{V}$.

The V and R2090 are measures of the slope of the flowduration curve, and these measurements are indicators of basin capacity to sustain base flow in a stream. Smaller values of V and R2090 indicate a flatter slope of the flow-duration curve, which represents sustained base flows, while the larger values of V and R2090 indicate a steeper slope of the flowduration curve, which may go to zero at the low end. The $\mathrm{V}$ was mapped in previous low-flow studies in Kentucky (Ruhl and Martin, 1991; Martin and Ruhl, 1993) by delineating areas of similar station value of $\mathrm{V}$ and similar geologic features. The "map" values of V for stations in Kentucky were computed as an area-weighted mean of the mapped V for use in the regression analysis. For those stations with drainage basins that extend outside Kentucky, the station values of streamflowvariability index were used in the previous study.

Reviews of mapped residuals from initial regressions based on the mapped values of $\mathrm{V}$ in the previous studies (Ruhl and Martin, 1991; Martin and Ruhl, 1993) and the updated low-flow frequencies indicated geographic patterns or bias could be addressed by modification of the map by using R2090 instead of V and (or) by defining subregions where changes in the geologic setting were indicated. Initial regressions that used the new and updated station values of V and R2090 showed that these were significant explanatory variables, with the station R2090 having slightly lower errors than the station V. Therefore, new maps of V and R2090 were developed, and the possibility of creating separate low-flow subregions was investigated.

Mapping of areas with equal values of V and R2090 was based on information from four sources: (1) LTCR gaging-station flow data (collected for 10 or more years), (2) short-term gaging-station flow data (collected for less than 10 years),

(3) LFPR station data, and (4) lithologic characteristics of surficial geology (U.S. Geological Survey, 2005). All these data helped to provide areal information on low-flow characteristics; therefore, these data were plotted on a map covering Kentucky and parts of adjoining States, and these data were then used collectively to define boundary lines for V and R2090.

New maps of V and R2090 were developed concurrently by use of similar procedures. The main source for mapping areas of equal V (and R2090) were the station values calculated from the LTCR station flow data. The calculated station values were plotted at each gaging station along with the drainage area boundary associated with the gaging station to visualize the extent over which the values applied. The 
areas of equal $\mathrm{V}$ were usually delineated along drainage basin boundaries where $\mathrm{V}$ values differed by 0.05 units or more.

Although many unique values of V were calculated for LTCR stations, mapped values were reduced to 15 most common values and rounded to the nearest 0.05 increment $(0.45,0.55$, $0.60,0.65,0.70,0.75,0.80,0.85,0.90,1.05,1.15,1.20,1.25$, $1.30,1.35)$. The other three sources of information were used to confirm or extend boundary decisions based on LTCR station values of $\mathrm{V}$. At least one $\mathrm{V}$ value based on flow data from a LTCR station was required to define an area of equal V; no area was defined by relying only on the other three sources of information for defining V. Often, multiple LTCR gaging stations were in large basins, and the $\mathrm{V}$ values differed by more than 0.05 units between the overall basin value and the values for subbasins. An example of this situation would be a large basin with one value for $\mathrm{V}$ and one or more subbasins in the large basin with a different value for V. A V value outside of the subbasin was required so that the combination of $\mathrm{V}$ for the subbasin and the estimated map V value for the area outside the subbasin approximates the $\mathrm{V}$ value for the entire basin. The combination was based on the proportion of area associated with each $\mathrm{V}$ value. For example, if a large basin had a V of 1.0 and half of the same basin (the subbasin) had a $\mathrm{V}$ value defined by another LTCR station to be 1.2 , then the remaining half of the basin would be assigned 0.8 so that the composite value for the entire basin of 1.0 would be achieved.

Data from 93 short-term gaging stations (less than 10 years of continuous daily mean flow data) in and near Kentucky and 188 of the LFPR stations presented in Ruhl and Martin (1991, table 2) were used to obtain approximate $\mathrm{V}$ values to assist in mapping. The approximate $\mathrm{V}$ values for the short-term gaging stations were calculated from the flow data by using the regression equations (equation 3 from Ruhl and Martin, 1991, to estimate $\left.7 Q_{10}\right)$, just as was done for the LTCR stations. The approximate $\mathrm{V}$ values derived from data at the LFPR stations were based on the values for $7 Q_{10}$ low flow. A relation was established between $7 \mathrm{Q}_{10}$ low flow and the $\mathrm{V}$ for the same flow record by using the data from the LTCR stations. First, the $7 \mathrm{Q}_{10}$ low flows at LTCR gaging stations were divided by the drainage area to obtain a $7 \mathrm{Q}_{10}$ low-flow yield. Then, a power relation between $\mathrm{V}$ and low-flow yield was developed (fig. 7). The linear relation between log-transformed $\mathrm{V}$ and log-transformed $7 \mathrm{Q}_{10}$ low-flow yield had a coefficient of determination of 0.741 , which indicates a reasonable relation between the two variables. The power form of the resulting equation to estimate $\mathrm{V}$ from $7 \mathrm{Q}_{10}(x)$ follows:

$$
V=0.405 x^{-0.08}
$$

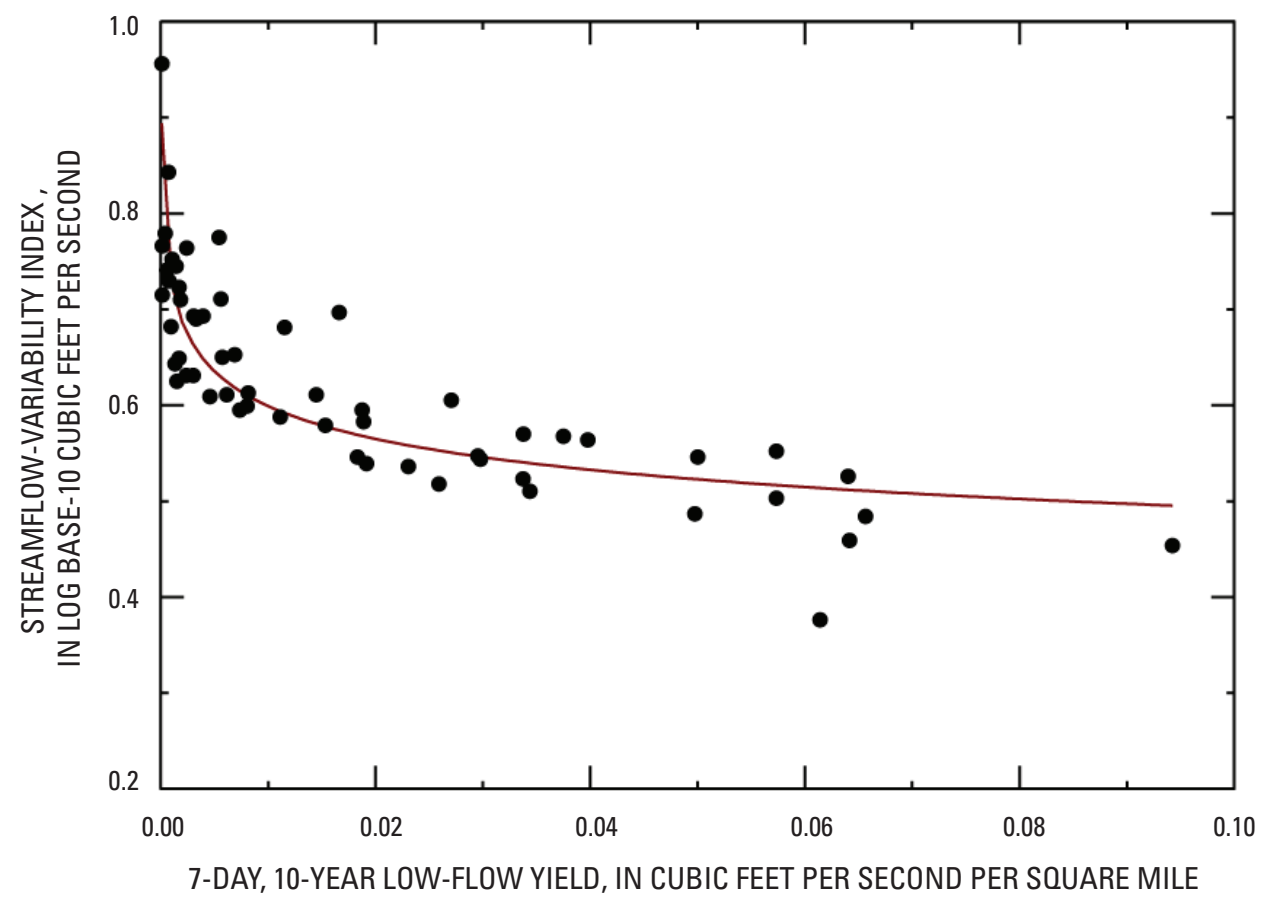

Figure 7. Relation between 7-day, 10-year low-flow yield and streamflow-variability index.

\section{EXPLANATION}

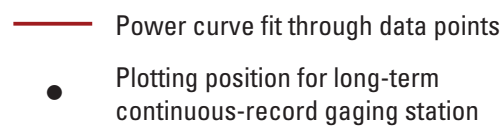


Equation 2 was then used to estimate V values at LFPR stations by using the $7 \mathrm{Q}_{10}$ low flow data for the LFPR stations. The $7 Q_{10}$ low flows at LFPR stations were divided by the drainage areas in square miles to obtain low-flow yields. Then $\mathrm{V}$ values at LFPR stations were calculated by inputting the yields for the LFPR station data into equation 2 and solving for V. Finally, the V values from all three sources were plotted on a map of Kentucky along with the surficial geology to guide in the mapping of areas of equal $\mathrm{V}$.

Boundary lines shown on the map for $\mathrm{V}$ (plate 2) are sometimes related to boundary lines for lithologic changes in surficial geology (fig. 3), and sometimes are not related. The Mississippian limestone in the western half of Kentucky does appear to have consistent effects on the well-sustained low flows because the $\mathrm{V}$ values in those areas were consistently near a value of 0.55 . As a result of the consistency, a polygon was defined around almost the entire area of limestone and given the $\mathrm{V}$ value of 0.55 . The LTCR station data often indicated a change in $\mathrm{V}$ values even though the lithologic characteristics of surface geology did not change. A specific lithology does not necessarily result in a consistent effect on groundwater discharge and low flow because other factors, such as basin slope or the degree of rock fracturing or modification, also can influence low-flow characteristics. Regardless of fine-scale changes in surficial geology or $\mathrm{V}$ values for small basins, areas smaller than $50 \mathrm{mi}^{2}$ were usually not defined because of the lack of gaging stations with drainage areas of such size. Such detailed mapping (polygons less than $50 \mathrm{mi}^{2}$ ) would infer a greater accuracy to the map than justified by the coverage of gaging station data. Because the map of $\mathrm{V}$ values had additional sources of information to define $\mathrm{V}$, such as low-flow yields from LFPR stations, the current (2010) map of $\mathrm{V}$ has been updated in several areas from the map presented in Martin and Ruhl (1993, plate 1). The updated V at ungaged locations can be obtained from a map of $\mathrm{V}$ for the entire State and parts of adjoining States that drain into Kentucky (plate 2).

\section{Low-Flow Regions}

Review of maps of the regression residuals (the observed minus the estimated low-flow statistic) indicated geographic patterns in the residuals centered in the Cumberland and the Mississippian Plateaus. Three low-flow regions (fig. 8) were created on the basis of the geographic patterns of the residuals and the geology. The need for area indicator variables in the regression equations for the lowest flow statistics $\left(7 Q_{10}\right.$ and $7 Q_{20}$ ) may be related to groundwater discharge during the lowest flows. The amount and distribution of groundwater discharge is reflected in the upper end of the flow-duration curve. Characteristics of the curves were observed from flow-duration curves in appendix 2 of Ruhl and others (1995). The flow-duration curves were observed for several typical stations in the areas of positive, negative, and mixed residuals. The flow-duration curves flattened out in the area of positive residuals during lowest flows; whereas, the curves usually steepened in the area of negative residuals. The difference in the curves is likely the result of the differences in geology between the two areas (fig. 3). The area of positive residuals (fig. 8) is karsted limestone and the area of negative residuals is shale and sandstone. The flow-duration curves were fairly straight or at least did not indicate consistent breaks in slope during lowest flows in the area of mixed residuals. The V-flow variable measures the overall slope of the flow-duration curve and, based on that slope, is used to estimate all the low-flow statistics. If the slope of the flow-duration curve breaks from the average at the lowest flows, the $\mathrm{V}$ variable is not wellsuited to express that break, and the regression equation will either underestimate (for curve flattening) or overestimate (for curve steepening). The region-indicator variable helps to compensate for breaks in the slope during lowest flows and makes little or no correction for the higher low-flow statistics $\left(30 \mathrm{Q}_{2}\right.$ and $\left.30 \mathrm{Q}_{5}\right)$.

\section{Logistic-Regression Analysis}

Logistic-regression equations were developed to estimate the probability of the annual minimum 7- and 30-day mean low flows being equal to zero by use of data for 112 long-term, continuous-record streamflow-gaging stations in Kentucky (tables 1 and 2). Procedures and assumptions of logistic regression are described in detail elsewhere (Tasker, 1989; Ludwig and Tasker, 1993; SAS Institute, Inc., 1995; Allison, 1999; Hosmer and Lemeshow, 2000; Helsel and Hirsch, 2002; Hortness, 2006; Bent and Steeves, 2006). Trial explanatory (independent) variables in the logistic regressions included numerous physical and climatic characteristics of each gaged basin (table 3). The dependent variables were the empirical probabilities, or observed frequencies, of zero values for the 7- and 30-day annual low flows at each of the long-term stations, expressed as a decimal value ranging from zero and one. The observed frequencies of zero flows at a given station were computed as the number of climate years in which the 7and 30-day low flows were zero, divided by the total number of climate years of record at the station (table 2). The final logistic-regression model is expressed in the following form:

$$
\text { PZERO }_{D}=\frac{1}{1+e^{\left(-b_{0}-b_{1} \log _{10}\left(x_{1}\right)-b_{2} \log _{10}\left(x_{2}\right) \ldots-b_{n} \log _{10}\left(x_{n}\right)\right)}}
$$

where

PZERO $_{D} \quad$ is the probability of the annual $D$-day low flow being zero,

$e \quad$ is the exponential constant, approximately equal to 2.71828 ,

$n \quad$ is the number of basin-characteristic explanatory variables in the regression,

$x_{i} \quad$ is the value of the $i^{\text {th }}$ basin characteristic, and

$b_{0}, b_{1}$, and $b_{n} \quad$ are the coefficients determined by maximizing the log-likelihood function. 


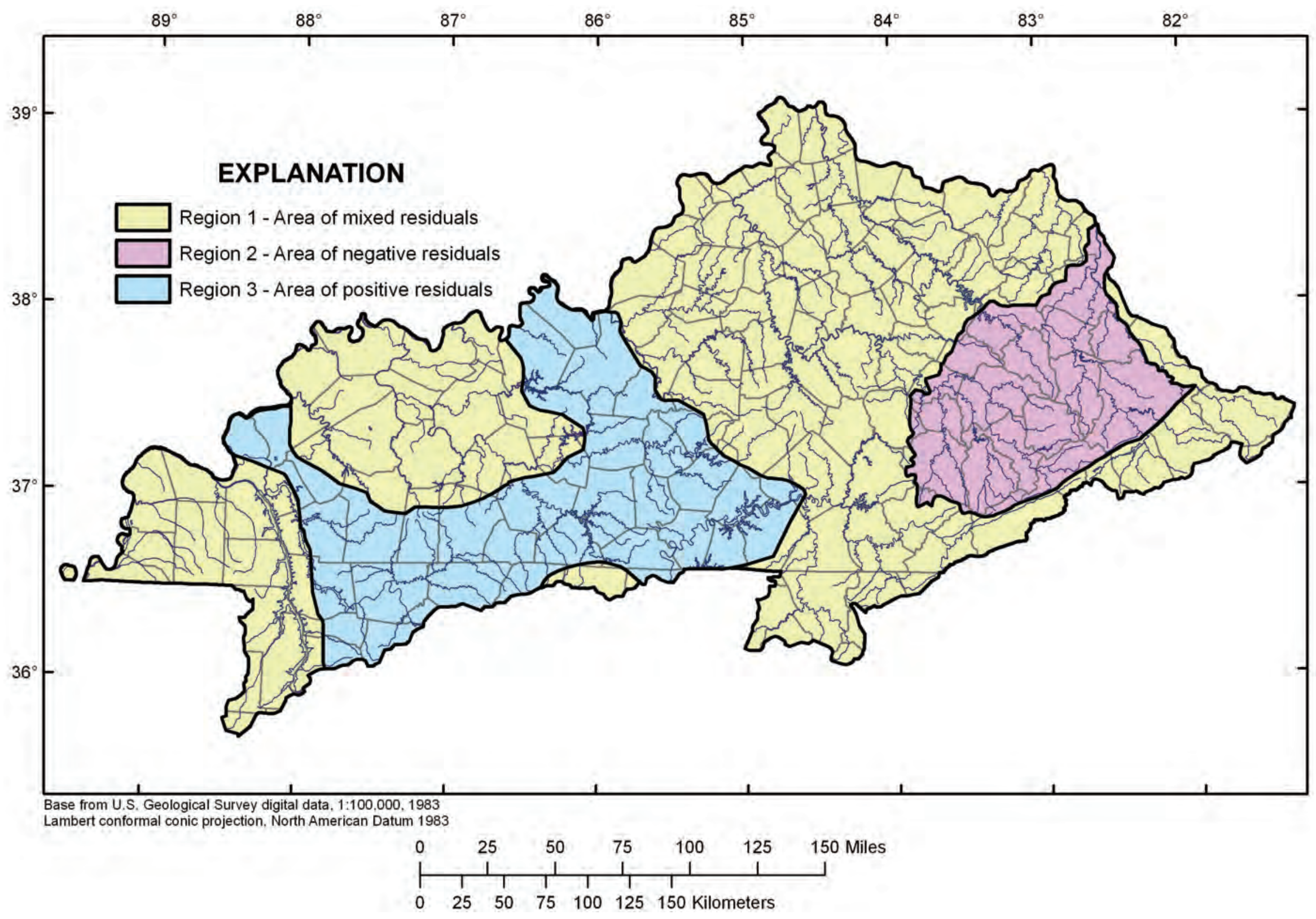

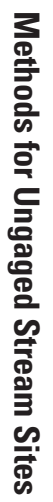

Figure 8A. Locations of the low-flow regions in Kentucky: Regions 1, 2, and 3 . 


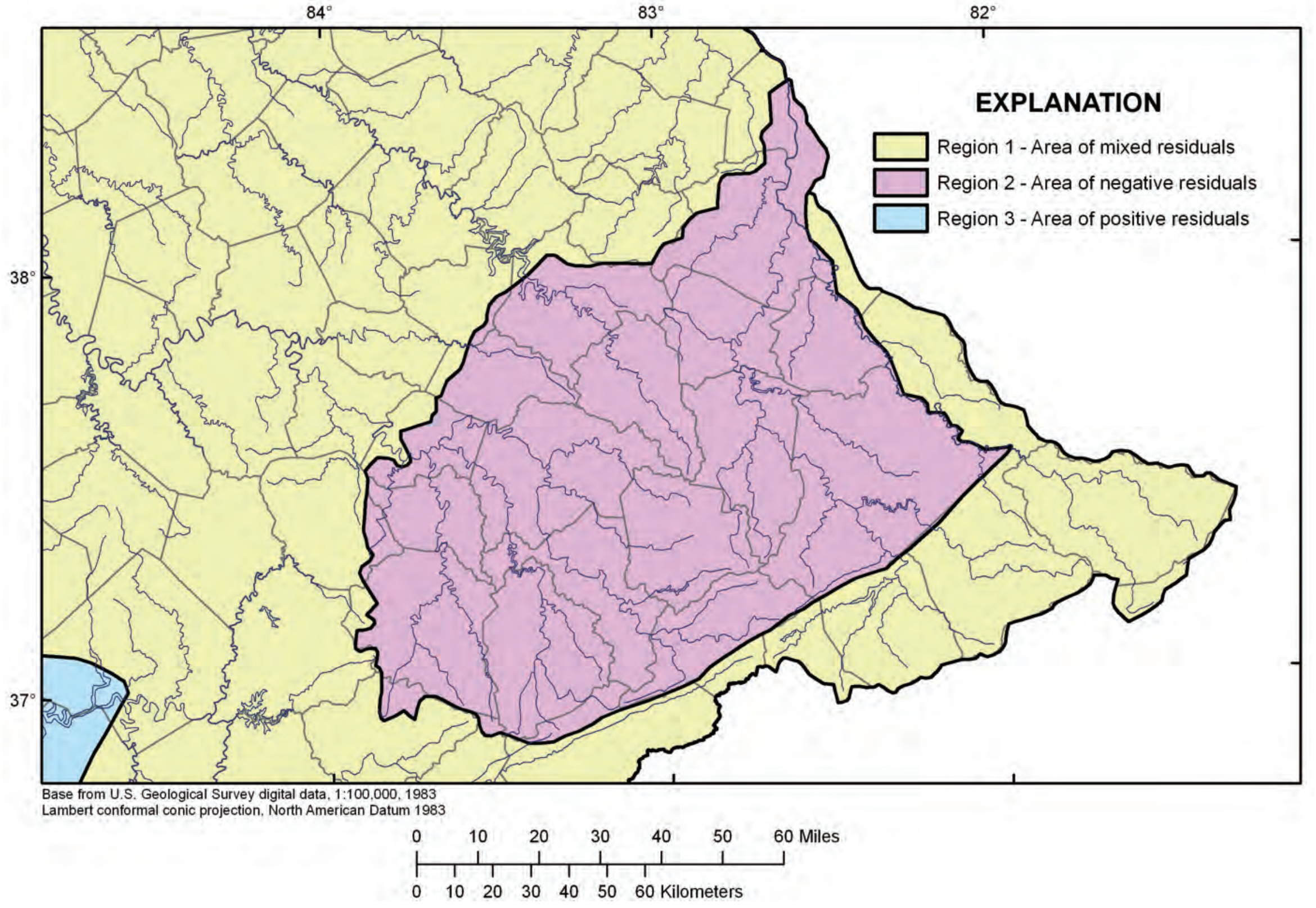

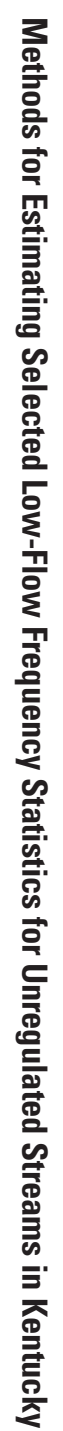

Figure 8B. Locations of the low-flow regions in Kentucky: Region 2 enlarged view (Cumberland Plateau vicinity). 


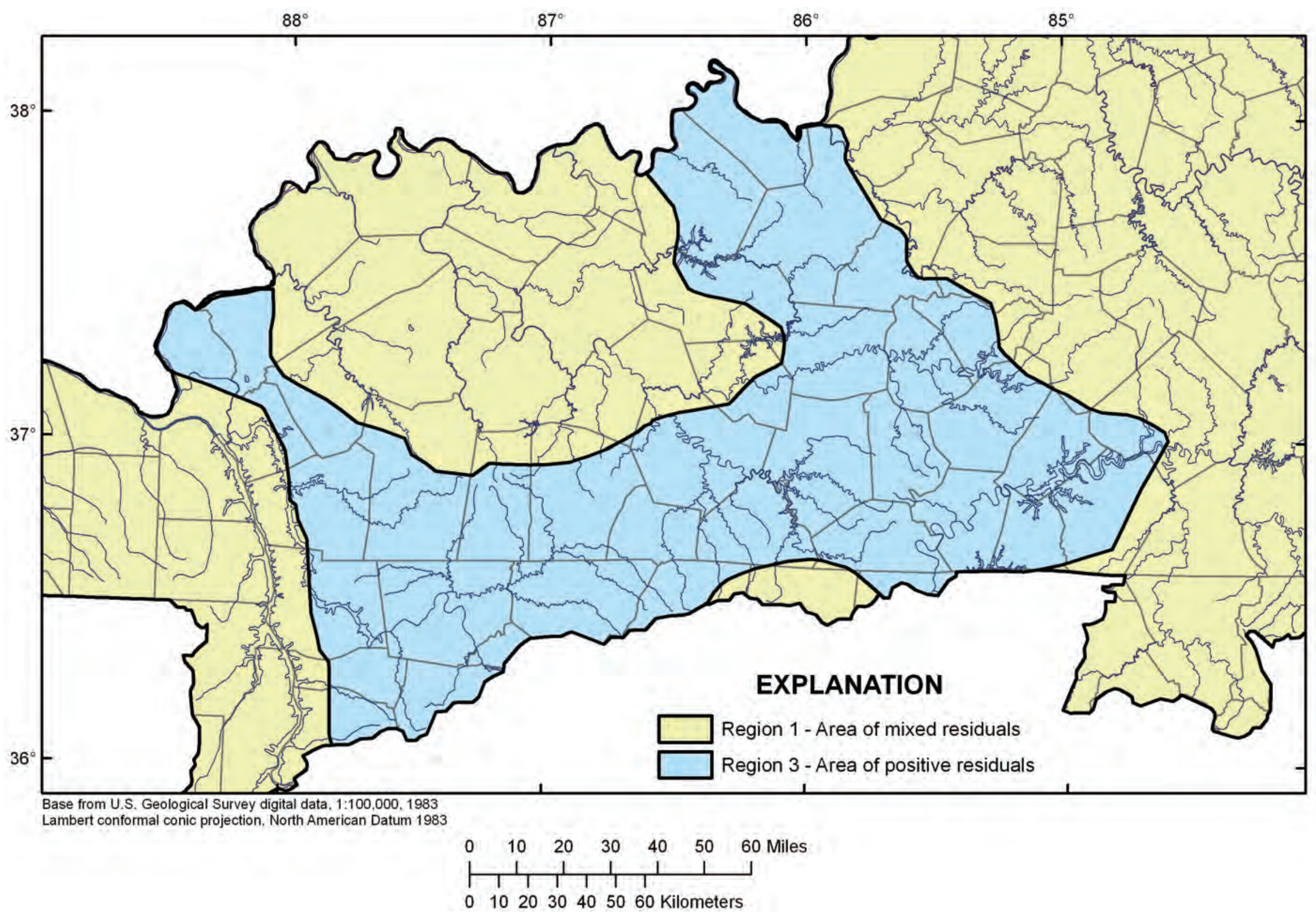

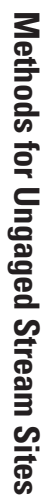

Figure 8C. Locations of the low-flow regions in Kentucky: Region 3 enlarged view (Mississippian Plateau vicinity). 


\section{Methods for Estimating Selected Low-Flow Frequency Statistics for Unregulated Streams in Kentucky}

The logistic-regression equations, applicable statewide, were developed by use of SAS statistical software (SAS Institute, Inc., 1995 and 2004). Weights were applied to each of the 112 gaging stations included in the regressions. The period of record at each gaging station, which is the total number of climate years, was used as the weight because the number of climate years is a measure of the reliability of the estimated low-flow characteristic, in this case, the annual probability of zero flow. The weights were centered, or standardized, by dividing each station period of record by the average period of record (22.8 years) for the 112 stations included in the logistic regression (table 2). The mean value of these standardized weights was, therefore, one (Stuckey, 2006).

Model selections were done by iterative step-forward, backward-elimination, stepwise, and score procedures to evaluate numerous alternative combinations of the explanatory variables. A significance level of 0.05 for the $p$-values of explanatory variables was used as the criteria for inclusion in these models. The final logistic-regression equations (table 4) included total drainage area and $\mathrm{V}$, mapped streamflow-variability index (table 2, plate 2), as the explanatory variables.

Analysis of the estimates provided by the logistic-regression estimating equations indicated optimal performance in terms of the percentage of gaging stations correctly classified as zero or nonzero flow for each low-flow statistic $\left(30 \mathrm{Q}_{2}\right.$, $30 \mathrm{Q}_{5}, 7 \mathrm{Q}_{2}, 7 \mathrm{Q}_{10}, 7 \mathrm{Q}_{20}$ ) varied depending on the particular 'cutpoint' probability used. Classification tables (SAS Institute, Inc., 1995; Hosmer and Lemeshow, 2000) (appendix 5) were developed by determining the numbers of correct and incorrect classifications of events (zero flow) and nonevents (nonzero flow) by comparison of the estimated probabilities to the zero and nonzero status of each low-flow statistic at the various probability cutpoints. The optimal cutpoints are shown in bold numbers in the classification tables. The logistic-regression equations were adjusted to operate at the optimal cutpoints by multiplying the probabilities computed from the logistic regression equation by the ratio of the standard cutpoints to the optimal cutpoints. For example, the standard cutpoint for $7 \mathrm{Q}_{2}$ is 0.5 (inverse of the return period, $1 / \mathrm{T}$ or $1 / 2$ ), at which 73.2 percent of stations were classified correctly. The optimal cutpoint is 0.985 , at which 93.8 percent of the stations were classified correctly. To get optimal results at the standard cutpoint for $7 \mathrm{Q}_{2}$, a conversion factor $(\mathrm{C}$, in table 4$)$ of $0.508(0.5$ divided by 0.985 ) was applied to the final logistic-regression equation. The percentage of the station low-flow frequencies correctly classified as zero or nonzero by use of the logisticregression equations ranged from 87.5 to 93.8 percent after the conversion factors were applied.

The logistic-regression equations are applied to determine if the statistic of interest is either zero or nonzero. The estimated probabilities of zero flows are compared to the standard probability cutpoints that equal the probability of the statistics of interest (inverse of the return period, $1 / \mathrm{T}$ ). If the estimated probability of zero flow is greater than the nonexceedance probability of the low-flow statistic of interest, then the lowflow statistic is estimated to be zero. For example, taking the $7 Q_{10}$ statistic, if the estimated probability of zero flow exceeds 0.1 , then the $7 \mathrm{Q}_{10}$ is estimated to be zero. Alternatively, for the $7 Q_{10}$ statistic, if the probability of zero flow is less than or equal to 0.1 , then the $7 \mathrm{Q}_{10}$ should be estimated by using the multiple-linear-regression equations for estimating nonzero low-flow statistics described in the next section.

Table 4. Logistic-regression equations for estimating the annual probability of zero flow for selected low-flow frequencies for unregulated streams in Kentucky.

$\left[C\right.$, coefficient to adjust to the optimal cutpoint probability; $P Z E R O_{30}$, annual probability the 30-day low flow equals zero; $P Z E R O_{7}$, annual probability the 7-day low flow equals zero; $e$, exponential constant, approximately equal to 2.71828; $A$, total drainage area in square miles; $V$, mapped streamflow-variability index (plate 2$)]$

\begin{tabular}{lcrc}
\hline $\begin{array}{c}\text { Low-flow } \\
\text { statistic }\end{array}$ & $\begin{array}{c}\text { Annual-zero-flow } \\
\text { probability equation }\end{array}$ & C & $\begin{array}{c}\text { Percentage } \\
\text { correctly classified }\end{array}$ \\
\hline 30Q2 & $\mathrm{C}$ & 0.505 & 98.2 \\
$30 \mathrm{Q} 5$ & $\mathrm{PZERO}_{30}=\frac{.242}{1+\mathrm{e}^{\left(5.67+1.72 \log _{10} \mathrm{~A}-10.6 \mathrm{~V}\right)}}$ & & \\
& & & \\
$7 \mathrm{Q} 2$ & $\mathrm{C}$ & 0.508 & \\
$7 \mathrm{Q} 10$ & $\mathrm{PZERO}_{7}=\frac{.182}{1+\mathrm{e}^{\left(4.95+2.25 \log _{10} \mathrm{~A}-12.6 \mathrm{~V}\right)}}$ & .111 & 83.8 \\
$7 \mathrm{Q} 20$ & & & 89.3 \\
\hline
\end{tabular}




\section{Multiple-Linear-Regression Analysis}

Multiple-linear-regression equations were developed by use of a total of 114 gaging stations, including 102 LTCR streamflow-gaging stations with at least 10 years of record not substantially affected by local diversions (table 2 ) and 12 LFPR stations. The regression analysis included exploratory use of OLS and WLS regressions to identify appropriate explanatory variables to include. WLS regression was used to compensate by weighting for differences in the length of record and the variance (time-sampling error) of annual low flows at the gaging stations included in the analysis.

Inspection of scatterplots showing relations among dependent and explanatory variables and plots of residuals from initial linear regressions indicated that logarithmic (base 10) transformation of the dependent and most of the explanatory variables would be appropriate. This transformation generally helped make the relations more linear and the residuals more uniform in variance about the regression line than before transformation. The relations between dependent and explanatory variables after transformation were consistent with the assumed linear form of the model. Only stations with nonzero low-flow statistics were included in the multiple linear regressions because the logarithmic transformation is not possible for stations with low-flow statistics equaling zero.

The general form of the multiple linear regression models developed in this study is

$$
\log \left(D Q_{T}\right)=b_{0}+b_{1} \log X_{1}+b_{2} \log X_{2}+\ldots+b_{n} \log X_{n}+\varepsilon
$$

where

$$
\begin{aligned}
& D Q_{T} \quad \text { is a low-flow statistic of D-days annual } \\
& \text { duration and T-years average return } \\
& \text { interval, } \\
& b_{0} \quad \text { is a constant (y-intercept), } \\
& b_{i}(i=1 \text { to } n) \quad \text { is the regression coefficient for the } i^{\text {th }} \\
& \text { explanatory variable, } \\
& X_{i}(i=1 \text { to } n) \quad \text { is the } i^{\text {th }} \text { explanatory variable, } \\
& \varepsilon \quad \text { is a random error component equal to model } \\
& \text { plus time-sampling error, and } \\
& n \quad \text { is the total number of explanatory variables. }
\end{aligned}
$$

The algebraically equivalent form when the $\log$ (base 10) transformation is used and when the equation is retransformed to the original units is

$$
D Q_{T}=10^{b 0} X_{1}^{b 1} X_{2}^{b 2} \ldots X_{n}^{b n}
$$

WLS regression is the most appropriate when stations in the network have differing periods of record, when the regression model has reduced r-square indicating that not a large proportion of variability is explained by the regression (when errors are elevated), and when the cross-correlation of station data is not strongly correlated to the distance separating the stations. Weights were estimated for each station included in the regression (Tasker, 1980). A regression model was developed for each of the low-flow statistics by using WLS regression. WLS regression solves for regression coefficients in the same manner as OLS regression, except that in WLS regression weights are assigned to each of the gages in the analysis depending on how accurate the estimates of hydrologic statistics are thought to be at each gage. Gages with long record length will generally produce estimates of low-flow statistics that have less uncertainty, or lower variance. The gages with longer record lengths are given greater weight in the WLS regression than stations with short record length that have estimates of the flow statistics with increased uncertainty.

Tasker (1980) developed a WLS regression scheme specifically for use with hydrologic frequency statistics such as $30 \mathrm{Q}_{2}$ or $7 \mathrm{Q}_{10}$. The weights are dependent on estimated modelerror variance and average time-sampling-error variance for the station, and the weights are calculated as

$$
\mathrm{W}_{1}=\frac{1}{\sigma_{\delta}^{2}+\mathrm{c}_{1}\left(\frac{1}{\mathrm{POR}}\right)}
$$

where

$$
\begin{aligned}
& \sigma_{\delta}^{2} \quad \text { is the model-error variance, } \\
& \mathrm{C}_{1}=\max \left[0, \bar{s}^{2}\left(1+\frac{\mathrm{K}^{2}}{2}\left(1+0.75 \overline{\mathrm{G}}^{2}\right)+\overline{\mathrm{K}} \overline{\mathrm{G}}\right]\right. \\
& P{ }^{\prime} \quad \text { is the number of years of record at gage } i \\
& \bar{s} \quad \text { is average standard deviation of the } \log \\
& \text { base-10 of annual low-flow time series } \\
& \text { at all gages, which is estimated by an } \\
& \text { independent 'sigma regression,' (Tasker } \\
& \text { and Stedinger, 1989), } \\
& \bar{G} \quad \text { is average skew of the annual log base-10 } \\
& \text { low-flow time series at all gages, and } \\
& \mathrm{K} \quad \text { is average } \mathrm{K} \text {-factor of Log-Pearson Type III } \\
& \text { distribution fitted to the gages used in the } \\
& \text { regression. }
\end{aligned}
$$

The model-error variance is a measure of the variance inherent in the imperfect model resulting from the fact that not all of the variability in the observed data is explained in the model. The total-error variance also includes a component caused by time-sampling-error variance, which is a measure of the variance caused by imperfect estimates of the true, but unknown, population low-flow statistic at each gage. The model-error variance is estimated from an initial OLS regression as:

$$
\sigma_{\delta}^{2}=\max \left[0, \sigma_{\mathrm{OLS}^{2}}-\mathrm{C}_{1}\left(\frac{1}{\mathrm{n}} \sum_{\mathrm{i}=1}^{\mathrm{n}} \frac{1}{\mathrm{POR}_{\mathrm{i}}}\right)\right]
$$

where

$$
\begin{gathered}
\sigma_{\mathrm{OLS}}^{2} \quad \text { is the standard error of the estimate from the } \\
\text { OLS regression fitting of the flow statistic } \\
\text { to the basin characteristics, total drainage } \\
\text { area and mapped streamflow-variability } \\
\text { index (plate 1), and } \\
\text { is the number of gages included in the } \\
\text { regression. }
\end{gathered}
$$


The WLS regression included 12 selected LFPR stations among the 114 stations used (table 2). These stations also were weighted by use of the Tasker method. However, the period of record used was 1 year for each climate year during which low-flow measurements were made, as much as a maximum of 10 years to avoid overweighting the LFPR stations. Other factors in the weighting for the LFPR stations were as estimated in the Stedinger and Thomas (1985) correlation to the LTCR index stations.

These estimates of the sampling-error and model-error variance are a benefit of the WLS method developed by Tasker (1980). This method provides a way to partition total-error variance into model-error and sampling-error variance. The model-error variance includes only the variance caused by the imperfect model. About 90 percent of the total-error variance in the regional low-flow equations developed in this study was model-error variance.

The alternative regression models were generated by use of several model-selection methods including all-possibleregression, forward-selection, backward-elimination, and stepwise-regression procedures (SAS Institute, Inc., 2004,) by using the prospective explanatory variables (table 3 ). Various factors were considered in evaluating alternative regression models, including (1) the coefficient of determination, the proportion of the variation in the response variable explained by the regression equation; (2) the standard error of the estimate, a measure of model-fitting error; (3) the prediction sum of squares (PRESS) statistic, a measure of model-prediction error; (4) the statistical significance of each alternative explanatory variable; (5) potential multicollinearity as indicated by the correlation of explanatory variables and the value of the variance-inflation factor (Montgomery and Peck, 1982); (6) the effort and modeling benefit of determining the values of each additional explanatory variable; and (7) the hydrologic validity of the signs and magnitudes of the regression exponents.

The best WLS-regression models included total drainage area (A), the mapped streamflow-variability index $(\mathrm{V})$, and, for the 7-day low-flow frequencies, the subregion-indicator variables, as explanatory variables (table 5 , fig. 8). In the final regression models for all the 7-day low-flow-frequency statistics, the same three variables were retained, even though in the equation for the largest of the 7-day low-flow frequencies, $7 Q_{2}$, the location variables were not significant at a p-value of 0.05 . These three variables were retained to keep the same model form and avoid inconsistent estimates for the different frequencies (for example, having $7 \mathrm{Q}_{10}$ exceed $7 \mathrm{Q}_{2}$ ). The p-value for the $7 Q_{10}$ low-flow estimating equation for region 3 was 0.06 . The remaining explanatory variables in these regression models were significant at a p-value of less than 0.05 .
The subregion-indicator variable was used in a combined regression that grouped stations from all three regions rather than developing a separate set of regression equations for each of the three regions. This grouping allowed pooling the information to provide one estimate of the common error variance and more residual degrees of freedom than would be possible otherwise. The addition of the region-indicator variables also reduced the $\mathrm{V}$ exponent somewhat in comparison to the value of the $\mathrm{V}$ exponent seen in the two-variable model, though $\mathrm{V}$ remains the most sensitive variable in the model. Note the region in which the stream site was located determined which regional estimating equation to use-upstream parts of the basin may drain from a different low-flow region.

Applying the Tasker weights did not change selection of the best two-variable models, which included $\mathrm{A}$ and $\mathrm{V}$ or flow-duration ratio, R2090. Applying the weights did affect selection of the third and fourth explanatory variables, none of which were used in the final equations. Flow-duration ratio worked satisfactorily as the second variable in combination with the karst-area coverage of percentage of basin not drained by sinkholes (Taylor and Nelson, 2008) as the third variable. Soil depth (U.S. Department of Agriculture-Natural Resources Conservation Service, 2007) and main-channel slope were other (third) explanatory variables that provided only small improvement in error (less than a 3-percentage-point decrease in error).

\section{Limitations and Accuracy of the Estimating Equations}

The regional regression models are applicable to unregulated streams in Kentucky that are not appreciably affected by local diversions, which commonly are associated with land development. Caution is warranted when applying the equations in areas where streamflows are affected by hydrologic discontinuities such as large springs and sinks common to karst terrain in areas underlain by limestone. Streamflows in these areas may vary unpredictably in karst drainageways. An accurate basin drainage area in karst terrain may be difficult (if not impossible) to determine solely on the basis of topographic divides.

The regression equations were developed by use of basin characteristics in a certain range of values. Drainage areas (A) of stations used in the regression analysis ranged from 0.04 to $1,984 \mathrm{mi}^{2}$, and mapped streamflow-variability index values ranged from 0.45 to 1.35 (figs. 9 and 10, table 6). Applications of the regression equations for estimates in basins with combinations of drainage area and mapped streamflow-variability index outside these two-dimensional sample spaces, the explanatory-variable hull, are extrapolations. Therefore, these equations should not be applied in basins with characteristics beyond these sample spaces represented by the characteristics of basins used to develop the regression equations. 
Table 5. Weighted-least-squares regression equations for estimating selected nonzero low-flow frequencies for unregulated streams statewide and in each low-flow region in Kentucky.

$\left[30 Q_{2}, 30\right.$-day, 2-year low flow; $A$, total drainage area; $V$, mapped streamflow-variability index (plate 2); $30 Q_{5}, 30$-day, 5 -year low flow; $7 Q_{2}, 7$-day, 2-year low flow; $7 Q_{10}$, 7-day, 10 -year low flow; $7 Q_{20}$, 7-day, 20-year low flow]

\begin{tabular}{|c|c|c|c|c|c|c|}
\hline \multirow{3}{*}{ Equation } & \multicolumn{3}{|c|}{ Standard error of estimate } & \multicolumn{3}{|c|}{ Standard error of prediction } \\
\hline & \multicolumn{2}{|c|}{ Average } & \multirow{2}{*}{$\begin{array}{c}\text { Range } \\
\text { Percent } \\
\end{array}$} & \multicolumn{2}{|c|}{ Average } & \multirow{2}{*}{$\begin{array}{c}\text { Range } \\
\text { Percent } \\
\end{array}$} \\
\hline & $\log _{10}$ & Percent & & $\log _{10}$ & Percent & \\
\hline \multicolumn{7}{|c|}{ Statewide } \\
\hline $30 Q_{2}=0.0141 A^{0.885} V^{-3.91}$ & 0.367 & 102 & +133 to -57.0 & 0.38 & 108 & +140 to -58.4 \\
\hline $30 Q_{5}=0.00302 A^{0.835} V^{-6.25}$ & .454 & 141 & +184 to -64.8 & .49 & 161 & +210 to -67.8 \\
\hline \multicolumn{7}{|c|}{ Region 1} \\
\hline $7 Q_{2}=0.00490 A^{0.847} V^{-5.54}$ & 0.452 & 140 & +183 to -64.7 & 0.48 & 157 & +205 to -67.2 \\
\hline $7 Q_{10}=0.00692 A^{0.774} V^{-3.75}$ & .499 & 166 & +216 to -68.3 & .56 & 208 & +265 to -72.6 \\
\hline $7 Q_{20}=0.00759 A^{0.732} V^{-3.40}$ & .518 & 177 & +230 to -69.3 & .58 & 226 & +284 to -73.4 \\
\hline \multicolumn{7}{|c|}{ Region 2} \\
\hline $7 Q_{2}=0.00383 A^{0.847} V^{-5.54}$ & 0.452 & 140 & +183 to -64.7 & 0.48 & 157 & +205 to -67.2 \\
\hline $7 Q_{10}=0.00177 A^{0.774} V^{-3.75}$ & .499 & 166 & +216 to -68.3 & .56 & 208 & +265 to -72.6 \\
\hline $7 Q_{20}=0.00136 A^{0.732} V^{-3.40}$ & .518 & 177 & +230 to -69.3 & .58 & 226 & +284 to -73.4 \\
\hline \multicolumn{7}{|c|}{ Region 3} \\
\hline $7 Q_{2}=0.00556 A^{0.847} V^{-5.54}$ & 0.452 & 140 & +183 to -64.7 & 0.48 & 157 & +205 to -67.2 \\
\hline $7 Q_{10}=0.0129 A^{0.774} V^{-3.75}$ & .499 & 166 & +216 to -68.3 & .56 & 208 & +265 to -72.6 \\
\hline $7 Q_{20}=0.0201 A^{0.732} V^{-3.40}$ & .518 & 177 & +230 to -69.3 & .58 & 226 & +284 to -73.4 \\
\hline
\end{tabular}

Figure 9. Total-drainage-area and mapped streamflowvariability-index sample space for the logistic-regression equations for estimating the probability of zero flow for unregulated streams in Kentucky.

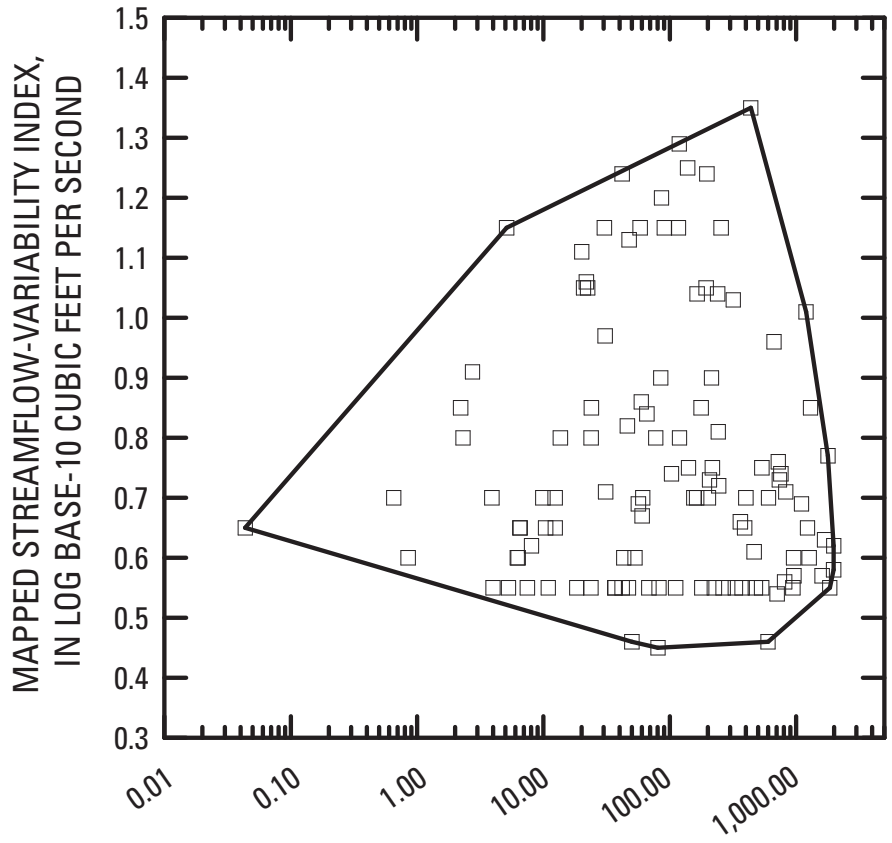

TOTAL DRAINAGE AREA, IN SQUARE MILES 

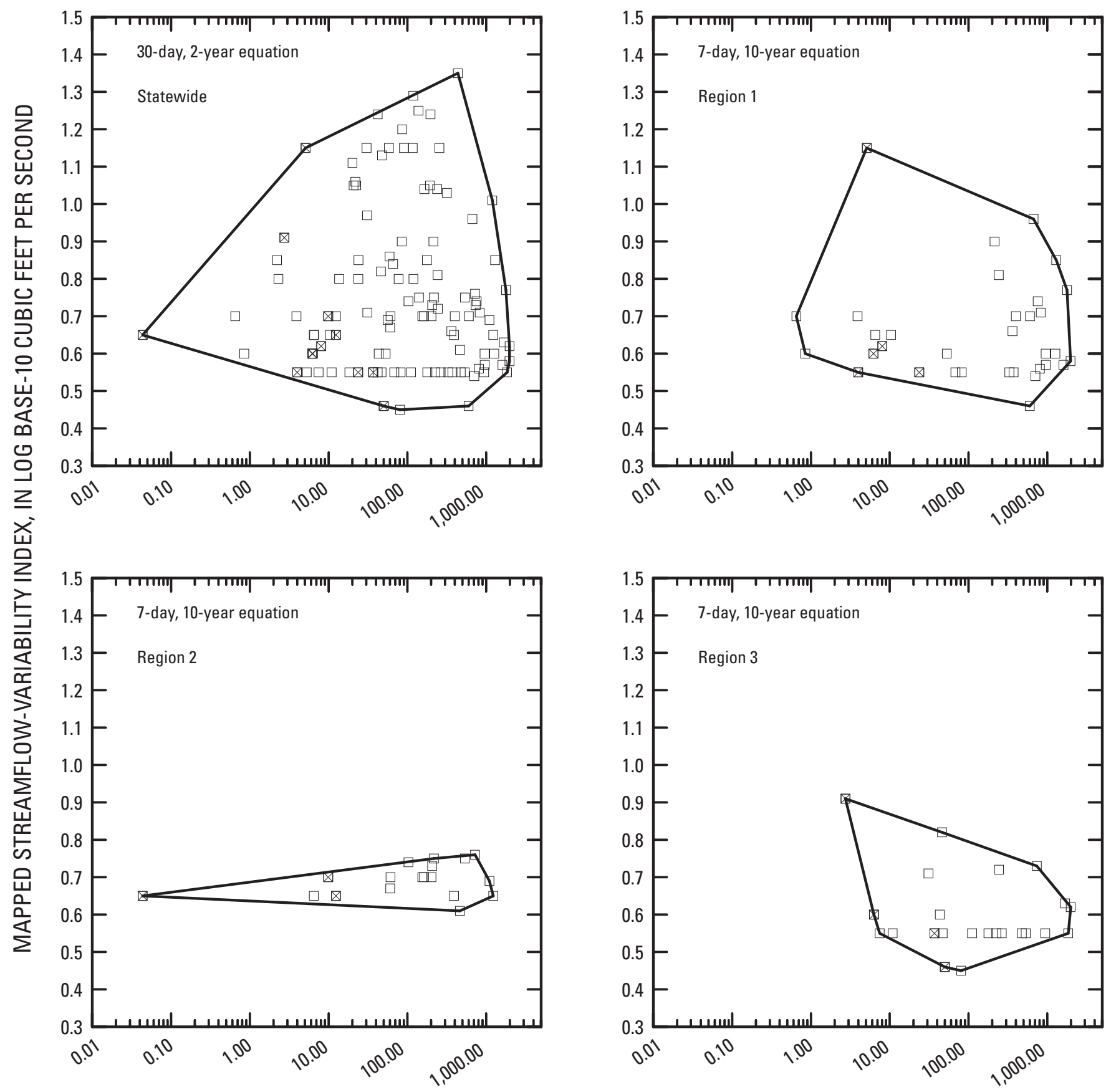

TOTAL DRAINAGE AREA, IN SQUARE MILES

\section{EXPLANATION}

$\otimes$ Low-flow, partial-record station

ㄴ Long-term, continuous-record station

Figure 10. Total-drainage-area and mapped streamflow-variability-index sample spaces for 30-day, 2-year and 7-day, 10-year lowflow-frequency estimating equations for unregulated streams in Kentucky. 
Table 6. Basin-characteristic ranges for the logistic-regression equations for estimating the annual probability of zero flow for selected low-flow frequencies and the weighted-least-squares regression equations for estimating selected nonzero low-flow frequencies for unregulated streams statewide and in each low-flow region in Kentucky.

[ $A$, total drainage area; $V$, mapped streamflow-variability index (plate 2); $P Z E R O_{7}$, annual probability the 7-day low flow equals zero; $P Z E R O_{30}$, annual probability the 30-day low flow equals zero; $30 Q_{2}, 30$-day, 2-year low flow; $30 Q_{5}$, 30-day, 5 -year low flow; $7 Q_{2}$, 7-day, 2-year low flow; $7 Q_{10}, 7$-day, 10 -year low flow; $7 Q_{20}$, 7-day, 20-year low flow]

\begin{tabular}{|c|c|c|c|c|c|}
\hline \multirow{2}{*}{$\begin{array}{c}\text { Low-flow } \\
\text { charactertistic }\end{array}$} & \multirow{2}{*}{$\begin{array}{l}\text { Number of } \\
\text { stations }\end{array}$} & \multicolumn{2}{|c|}{$\begin{array}{c}\text { A } \\
\text { (square miles) }\end{array}$} & \multicolumn{2}{|c|}{$\begin{array}{l}V \text { (base-10 logarithms of } \\
\text { cubic feet per second) }\end{array}$} \\
\hline & & Minimum & Maximum & Minimum & Maximum \\
\hline \multicolumn{6}{|c|}{ Statewide } \\
\hline $\mathrm{PZERO}_{7}, \mathrm{PZERO}_{30}$ & 112 & 0.04 & 1,984 & 0.45 & 1.35 \\
\hline $30 Q_{2}$ & 114 & .04 & 1,984 & .45 & 1.35 \\
\hline $30 Q_{5}$ & 107 & .04 & 1,984 & .45 & 1.35 \\
\hline \multicolumn{6}{|c|}{ Region 1} \\
\hline $7 Q_{2}$ & 52 & 0.65 & 1,976 & 0.46 & 1.35 \\
\hline $7 Q_{10}$ & 33 & .65 & 1,976 & .46 & 1.15 \\
\hline $7 Q_{20}$ & 32 & .65 & 1,976 & .46 & 1.15 \\
\hline \multicolumn{6}{|c|}{ Region 2} \\
\hline $7 Q_{2}$ & 25 & 0.04 & 1,230 & 0.61 & 0.85 \\
\hline $7 Q_{10}$ & 18 & .04 & 1,230 & .61 & .76 \\
\hline $7 Q_{20}$ & 17 & .04 & 1,230 & .61 & .76 \\
\hline \multicolumn{6}{|c|}{ Region 3} \\
\hline $7 Q_{2}$ & 26 & 2.74 & 1,984 & 0.45 & 0.91 \\
\hline $7 Q_{10}$ & 23 & 2.74 & 1,984 & .45 & .91 \\
\hline $7 Q_{20}$ & 21 & 2.74 & 1,984 & .45 & .91 \\
\hline
\end{tabular}

Application of the equations near or outside the boundaries of the regression sample spaces may produce unexpected results, such as estimates of $7 Q_{10}$ exceeding $7 Q_{2}$ (though this result is uncommon and generally the differences are expected to be minimal) or estimates of $7 Q_{20}$ exceeding $7 Q_{10}$, which may be more common. Inconsistent results also may be caused by differing number and characteristics of basins used to develop the multiple-linear WLS regression for the different low-flow frequencies considered (table 5). Only the gaging stations with nonzero low-flow statistics can be included in these WLS regressions - so, for example, a station with a nonzero $7 Q_{2}$ and a zero $7 Q_{10}$ was included in the $7 Q_{2}$ regression but was not included in the $7 \mathrm{Q}_{10}$ regression. Consequently, the applicable sample spaces differ somewhat for each low-flow frequency. The more extreme low-flow frequencies have progressively fewer gaging stations included in these regressions than the less extreme low-flow frequencies. Caution is warranted in applying the equations for basins with characteristics approaching the maximum and minimum limits (table 6) and the periphery of the sample spaces (fig. 10). If conflicting results may be obtained (such as $7 Q_{20}$ exceeding $7 Q_{10}$ and $7 Q_{10}$ exceeding $7 Q_{2}$ ) the results for the larger recurrence interval can be designated as less than $(<)$ the results for the smaller recurrence interval.
The average standard error of prediction of the final multiple-linear regression model - a measure of the accuracy of the regression estimates compared to observed data for stations excluded from the regression-ranged from 108 to 226 percent (table 5). The $30 \mathrm{Q}_{2}$ regression equations have the smallest standard errors of prediction, and the $7 Q_{20}$ regression equations have the largest standard errors of prediction. Average standard error of prediction was estimated as the square root of the PRESS divided by the error degrees of freedom (Montgomery and Peck, 1982; SAS Institute, Inc., 1985; and Choquette, 1988). The procedure used for computing PRESS is considered a form of data splitting and can be applied as a model-validation tool. The accuracy of the three-variable model predictions for ungaged sites similar to those predictions used in the regression could be expected to compare favorably to the standard error of prediction.

A scatterplot of the $7 Q_{10}$ computed from the streamflow-gaging-station data and the values estimated from the regression equations (fig. 11) shows reduced residuals and a slight tendency to underestimate the $7 \mathrm{Q}_{10}$ above $20 \mathrm{ft}^{3} / \mathrm{s}$. 

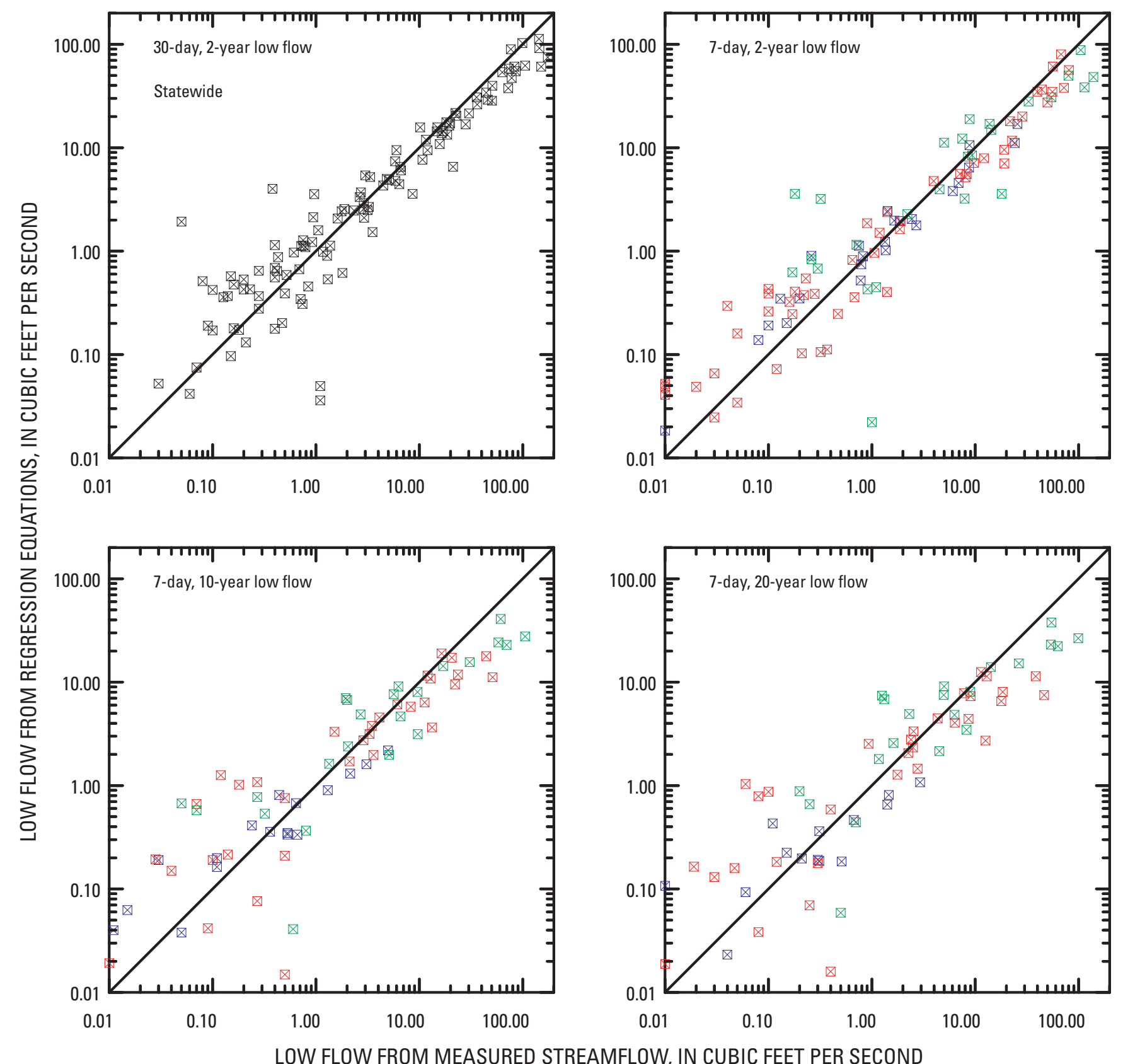

LOW FLOW FROM MEASURED STREAMFLOW, IN CUBIC FEET PER SECOND

\section{EXPLANATION}

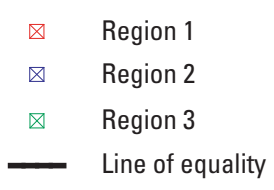

Figure 11. Comparison of selected low-flow frequencies estimated from measured streamflow and from regression equations for unregulated streams in Kentucky.

The underestimation tendency may be associated with increased error and bias in the values of mapped streamflowvariability index for large basins. The reduced residuals are probably related to generally reduced time-sampling error (long periods of record) for the stations having large values of the low-flow frequency statistic. Less variability in the streamflow response would be expected for large basins as compared to small basins. Maps showing the magnitude and distribution of residuals in the final regressions for $30 \mathrm{Q}_{2}$ and $7 \mathrm{Q}_{10}$ are shown in figures 12 and 13, respectively. 


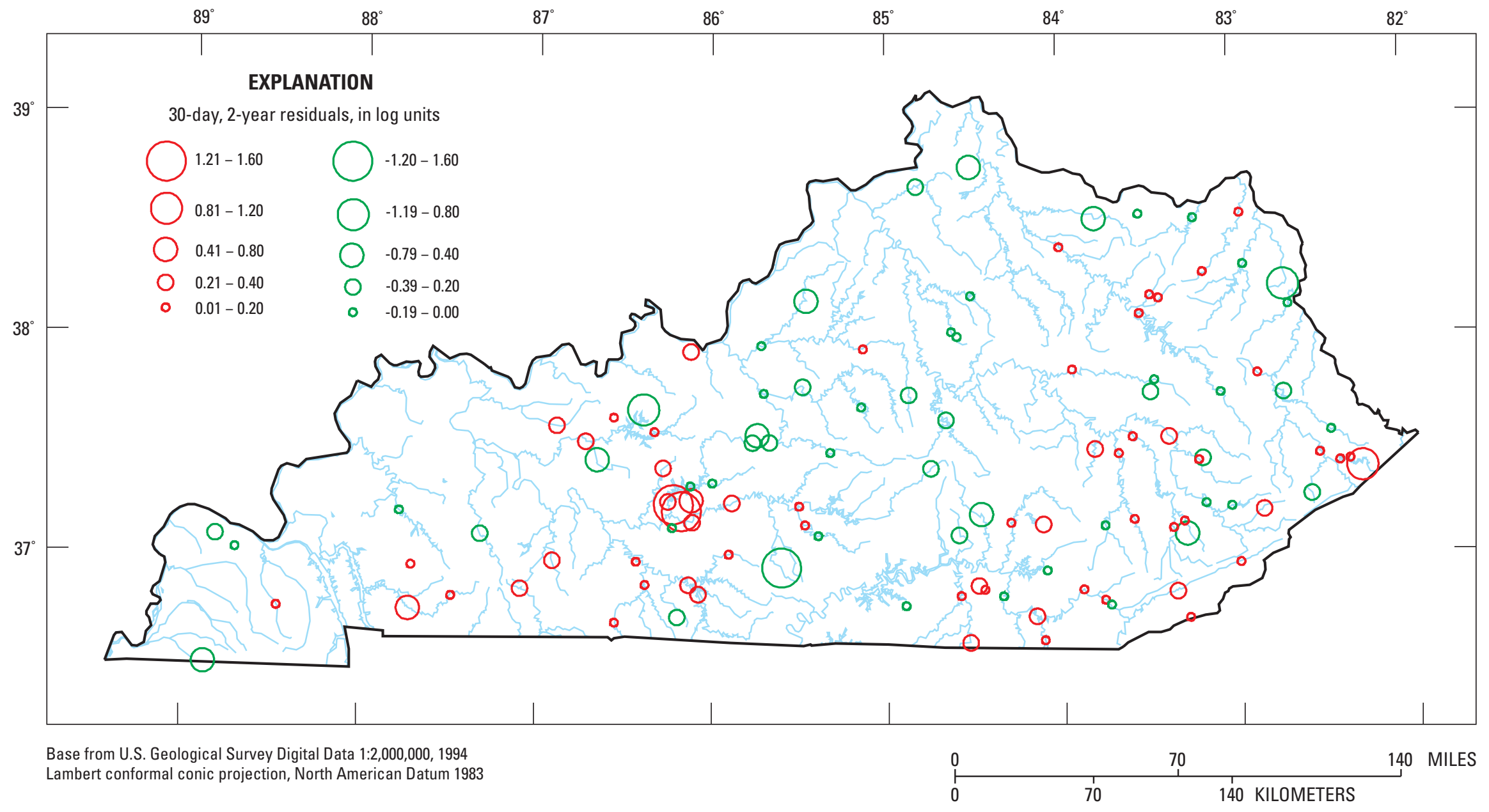

Figure 12. Residuals for the 30-day, 2-year low-flow regressions in Kentucky. 


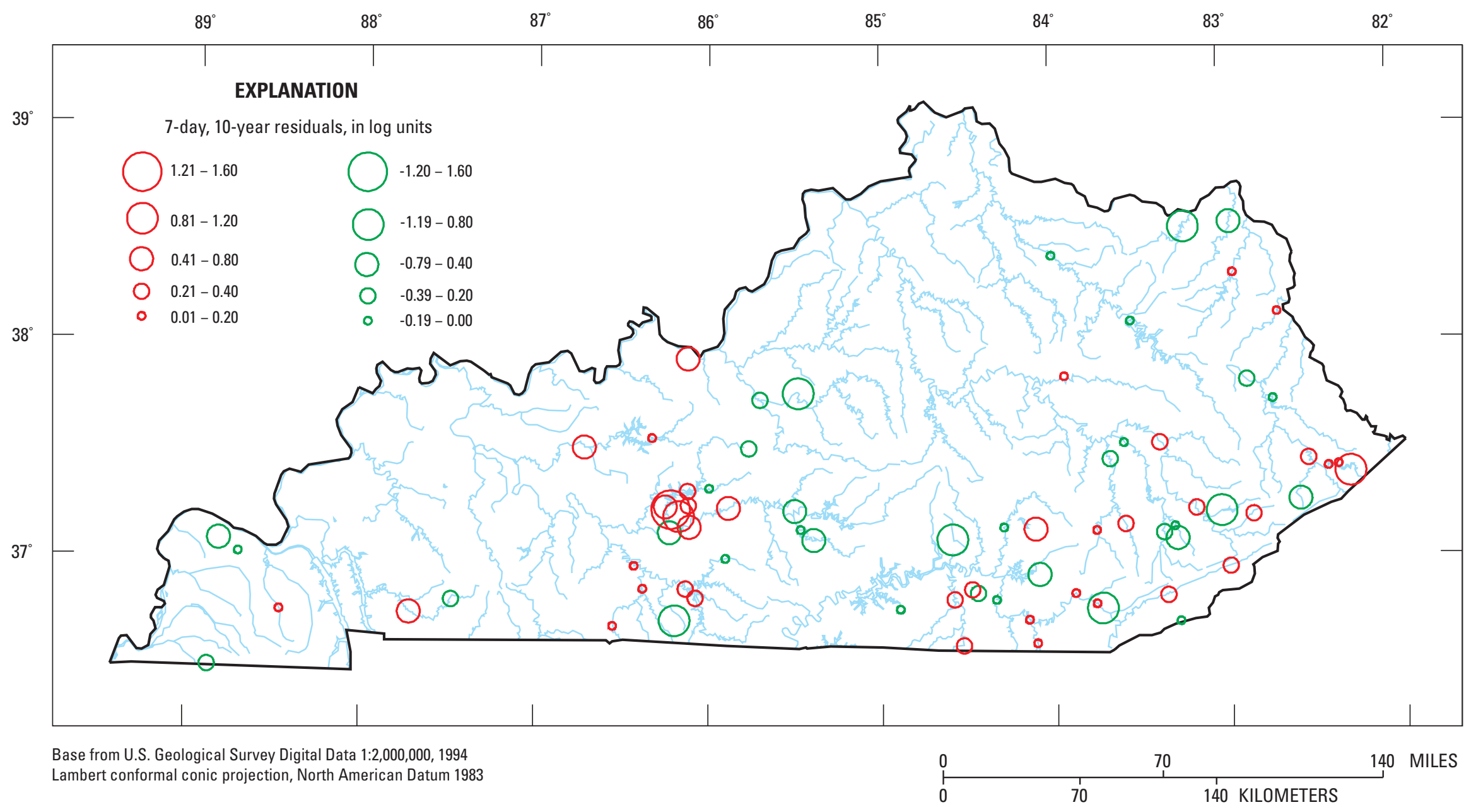

Figure 13. Residuals for the 7-day, 10-year low-flow regressions in Kentucky. 
The elevated percentage errors $(>100)$ result, in part, from the increased scatter in estimates for small basins and from the zero-bounded low-flow frequency statistics. Also, the large percentage errors may not correspond to large flow magnitudes. For example, a $7 \mathrm{Q}_{10}$ estimate of $1 \mathrm{ft}^{3} / \mathrm{s}$ that has a standard error of prediction ranging from -72.6 to 265 percent (table 5), results in a standard error flow range of 0.27 to $3.65 \mathrm{ft}^{3} / \mathrm{s}$, though this error range does exceed one order of magnitude. Typically, low-flow statistics have the largest percentage errors, followed by peak-flow statistics (Hodgkins and Martin, 2003), and then mean annual flow statistics (Martin, 2002), which have the smallest percentage errors.

\section{Example Applications of the Estimating Equations}

Procedures for using the estimating equations are described in the following examples:

\section{Example 1}

An estimate of the $7 Q_{10}$ low flow is needed for an ungaged stream site in Region 1. The site has the following drainage-basin characteristics: A, $400 \mathrm{mi}^{2}$; and V, 1.15. First, confirm that the basin characteristics are in the acceptable ranges defined for this statistic and Region 1 (table 6 and figs. 9 and 10), which is correct.

Next, the probability of the annual low flow being zero is computed from the logistic regression equation (table 4):

$$
\begin{aligned}
& \text { PZERO } 7=\frac{C}{1+\mathrm{e}^{4.95+2.25 \log _{10} \mathrm{~A}-12.6 \mathrm{~V}}} \\
& \text { PZERO7 }=\frac{0.182}{1+\mathrm{e}^{4.95+2.25 \log _{10} 400-12.6(1.15)}} \\
& \text { PZERO7 }=\frac{0.182}{1+\mathrm{e}^{-4.363}} \\
& \text { PZERO7 }=0.18>0.10
\end{aligned}
$$

Therefore, $7 \mathrm{Q}_{10}$ is zero.

\section{Example 2}

An estimate of the $7 Q_{10}$ low flow and the standard error of prediction are needed for an ungaged stream site in Region 3. The site has the following drainage-basin characteristics: A, $200 \mathrm{mi}^{2}$; and V, 0.55. First, confirm that the basin characteristics are in the acceptable ranges defined for this statistic and Region 3 (table 6 and figs. 9 and 10), which is the case.

$$
\text { PZERO7 }=\frac{C}{1+\mathrm{e}^{4.95+2.25 \log _{10} \mathrm{~A}-12.6 \mathrm{~V}}}
$$

$$
\begin{aligned}
& \text { PZERO7 }=\frac{0.182}{1+\mathrm{e}^{4.95+2.2510 \log _{10} 200-12.66(0.55)}} \\
& \text { PZERO7 }=\frac{0.182}{1+\mathrm{e}^{3.197}} \\
& \text { PZERO7 }=0.007<0.10
\end{aligned}
$$

Therefore, $7 \mathrm{Q}_{10}$ is nonzero and should be computed by using the WLS regional estimating equation for the 7-day, 10-year low flow in Region 3 (table 5),

$$
\begin{aligned}
& 7 Q_{10}=0.0129 A^{0.774} V^{-3.75} \\
& 7 Q_{10}=0.0129(200)^{0.774}(0.55)^{-3.75} \\
& 7 Q_{10}=7.33 f t^{3} / s
\end{aligned}
$$

The standard errors of prediction for the $7 \mathrm{Q}_{10}$ ranges from -72.6 percent to +265 percent (table 5 ), and values are computed as

$$
7.33-0.726(7.33)=2.01 f t^{3} / s
$$

and

$$
7.33+2.65(7.33)=26.7 f t^{3} / s
$$

\section{Example 3}

An estimate of the $30 \mathrm{Q}_{2}$ low flow is needed for a stream site having drainage areas of 40 and $160 \mathrm{mi}^{2}$ and streamflowvariability index zones of 0.65 and 0.75 , respectively. First, confirm that the basin characteristics are in the acceptable ranges defined for this statistic (table 6 and figs. 9 and 10), which is true. The next step is to determine if the $30 \mathrm{Q}_{2}$ is zero by using the logistic regression equation (table 4 ).

When a drainage basin includes contributing drainage area from more than one streamflow-variability index zone, the estimating equations should be applied as though the entire basin is in each specific streamflow-variability index zone, then a final estimate is obtained by area-weighting each estimate to provide a composite result.

Begin by applying the estimating equation as though the entire drainage basin is in streamflow-variability index zone 0.65 :

$$
\begin{aligned}
& \text { PZERO30 }=\frac{C}{1+\mathrm{e}^{5.67+1.72 \log _{10} \mathrm{~A}-10.6 \mathrm{~V}}} \\
& \text { PZERO30 }_{0.65}=\frac{0.505}{1+\mathrm{e}^{5.67+1.72 \log _{10}(200)-10.6(0.65)}} \\
& \text { PZERO 30 }_{0.65}=\frac{0.505}{1+\mathrm{e}^{2.74}} \\
& \text { PZERO } 30_{0.65}=0.03
\end{aligned}
$$


Next, apply the estimating equation as though the entire drainage basin is in streamflow-variability index zone 0.75 :

$$
\begin{aligned}
& \text { PZERO30 }_{0.75}=\frac{0.505}{1+\mathrm{e}^{5.67+1.72 \log _{10}(200)-10.6(0.75)}} \\
& \text { PZERO3O }_{0.75}=\frac{0.505}{1+\mathrm{e}^{1.68}} \\
& \text { PZERO30 }_{0.75}=0.08
\end{aligned}
$$

Finally, multiply each of the estimates by the proportion of the total drainage area represented by each estimate to obtain the area-weighted composite estimate:

$$
\begin{aligned}
& \text { PZERO30 }=0.2 \times 0.03+0.8 \times 0.08 \\
& \text { PZERO30 }=0.07<0.50
\end{aligned}
$$

Therefore, the PZERO30 is less than the annual nonexceedance probability, the reciprocal of the return period, $1 / \mathrm{T}$, or $1 / 2=0.50$, the $30 \mathrm{Q}_{2}$ is nonzero and should be estimated by use of the regional estimating equation for the $30 \mathrm{Q}_{2}$ (table 5). These estimating equations also should be applied as though the entire basin is in each specific streamflow-variability-index zone, and a final estimate is obtained by area-weighting each estimate to provide a composite result:

$$
\begin{aligned}
& 30 Q_{2}=0.0141 A^{0.885} V^{-3.91} \\
& 30 Q_{2}=0.0141 \times 200^{0.885} \times 0.65^{-3.91} \\
& 30 Q_{2}=8.26 f t^{3} / s
\end{aligned}
$$

Next, compute an estimate as though the entire basin is in streamflow-variability-index area 0.75 :

$$
\begin{aligned}
& 30 Q_{2}=0.0141 \times 200^{0.885} \times 0.75^{-3.91} \\
& 30 Q_{2}=4.72 \mathrm{ft}^{3} / \mathrm{s}
\end{aligned}
$$

Finally, multiply each of the estimates by the proportion of the total drainage area represented by each estimate to obtain the area-weighted composite estimate:

$$
\begin{aligned}
& 30 Q_{2}=0.20 \times 8.26+0.80 \times 4.72 \\
& 30 Q_{2}=5.43 \mathrm{ft}^{3} / \mathrm{s}
\end{aligned}
$$

\section{Weighted Drainage-Area-Ratio Method}

If a low-flow frequency is available for a gaged location of a stream reach and an estimate is needed at an ungaged point on the same stream, then a weighting procedure can be used (Carpenter, 1983; and Koltun and Whitehead, 2002). Two conditions must be met to use this method: (1) the drainage area of the ungaged site should differ by no more than 50 percent from that of the gaged site (ranging from 50 to 150 percent of the drainage area of the gaged site), and (2) the entire drainage basin of the ungaged site must be in the same streamflow-variability index area (plate 2). These conditions limit the possibility of hydrologic dissimilarity between the gaged and ungaged sites. The second condition is necessary because a linear relation between the low-flow-frequency values at the gaged and ungaged sites is assumed.

A weighted estimate can be computed as

$$
\mathrm{DQ}_{\mathrm{T}_{\mathrm{UW}}}=\mathrm{DQ}_{\mathrm{Tu}}\left[\mathrm{R}-\left(\frac{2(|\Delta \mathrm{A}|)(\mathrm{R}-1)}{\mathrm{A}_{\mathrm{g}}}\right)\right]
$$

where

$$
R=\frac{D Q_{T_{g m}}}{D Q_{T_{g r}}}
$$

and

$$
\begin{aligned}
& \mathrm{DQ}_{\mathrm{Tum}_{\mathrm{um}}} \text { is the weighted low-flow frequency, } D Q_{T} \text {, for } \\
& \text { the ungaged site; } \\
& \mathrm{DQ}_{\mathrm{Tu}} \quad \text { is the regression estimate of the } D Q_{T} \text { for the } \\
& \text { ungaged site; } \\
& D Q_{T_{\mathrm{gm}}} \quad \text { is the } D Q_{T} \text { determined for the gaged site from } \\
& \text { measured streamflow data; } \\
& \mathrm{DQ}_{\mathrm{Tgr}} \quad \text { is the regression estimate of the } D Q_{T} \text { for the } \\
& \text { gaged site; } \\
& |\Delta A| \quad \text { is the absolute value of the difference between } \\
& \text { the drainage areas of the gaged site and the } \\
& \text { ungaged site; and } \\
& A_{g} \quad \text { is the drainage area of the gaged site. }
\end{aligned}
$$

As the difference in drainage area between the gaged and ungaged site approaches 50 percent, the value of the weighting factor in brackets in equation 9 approaches 1 and no longer has an effect on the regression estimate at the ungaged site.

\section{Summary}

Low-flow frequencies are needed for effective management of water resources. Decisions related to waste-load allocations, discharge and withdrawal permits, water-supply planning, and in-stream flow requirements depend on estimates of low-flow frequencies, and methods for estimating low-flow frequencies at ungaged stream sites are part of this need. The U.S. Geological Survey, in cooperation with the Kentucky Division of Water, made estimates of the 7-day mean low flows for recurrence intervals of 5,10 , and 20 years $\left(7 \mathrm{Q}_{2}\right.$, $7 \mathrm{Q}_{10}$, and $7 \mathrm{Q}_{20}$ ) and 30-day mean low flows for recurrence intervals of 2 and 5 years $\left(30 \mathrm{Q}_{2}\right.$ and $\left.30 \mathrm{Q}_{5}\right)$ at 121 streamflowgaging stations in Kentucky with data through the 2006 climate year and developed regional regression equations for estimating low-flow characteristics of unregulated streams in Kentucky. Data were screened to identify the periods of homogeneous, unregulated flows by use of annual low-flow time-series plots, trend tests, available information on permitted water discharges and withdrawals, and double-mass curves for comparing annual low flows at each gaging station to flows at a reference gaging station. 
Logistic-regression equations were developed for estimating the probability of the annual 7- and 30-day low flows being zero. Weighted-least-squares regression equations were developed for estimating the magnitude of the nonzero $7 \mathrm{Q}_{2}$, $7 \mathrm{Q}_{10}, 7 \mathrm{Q}_{20}, 30 \mathrm{Q}_{2}$, and $30 \mathrm{Q}_{5}$ low flows. Three low-flow regions were defined for applying the equations used for estimating the 7-day low-flow frequencies, while separate regions for estimating the 30-day low-flow frequencies were not necessary.

The explicit explanatory variables in the regression equations include total drainage area and the mapped streamflowvariability index measured from a revised statewide coverage of this characteristic. The percentage of the station low-flow frequencies correctly classified as zero or nonzero by use of the logistic-regression equations ranged from 87.5 to 93.8 percent. The average standard errors of prediction of the weighted-least-squares regression equations ranged from 108 to 226 percent.

The estimating equations can be applied by (1) determining the basin characteristics required for the appropriate equation, (2) checking to ensure that the basin characteristics are in the range of values used to develop the equation, and (3) substituting the basin-characteristic values for the variables in the estimating equations. The user first determines the probability of the low-flow frequency having a value of zero by use of the logistic-regression equation, and if a nonzero value is likely, the low-flow frequency value is estimated by use of the weighted-least-squares regression equations as described in the example applications presented in this report.

\section{Acknowledgments}

The authors thank the KDOW for long-term support of the USGS streamflow-data-collection program and this investigation. Special thanks to Julie Kiang, USGS, for guidance on the methods used, and Hugh Nelson, USGS, for determination of numerous basin characteristics. The authors also express their appreciation to numerous other USGS employees who have collected and analyzed the streamflow data and assisted in completing this report.

\section{References Cited}

Allen, D.M., 1971, Mean square error of prediction as a criterion for selecting prediction variables: Technometrics, v. 13, p. 469-475.

Allen, D.M., 1974, The relationship between variable selection and data augmentation and a method for prediction: Technometrics, v. 16 , no. 1 , p. 125-127.

Allison, P.D., 1999, Logistic regression using SAS - Theory and application: Cary, N.C., SAS Institute, Inc., 288 p.
Beaber, H.C., 1970, A proposed streamflow data program for Kentucky: U.S. Geological Survey Open-File Report, 48 p.

Bent, G.C., and Steeves, P.A., 2006, A revised logistic regression equation and an automated procedure for mapping the probability of a stream flowing perennially in Massachusetts: U.S. Geological Survey Scientific Investigations Report 2006-5031, 107 p.

Carpenter, D.H., 1983, Characteristics of streamflow in Maryland: Maryland Geological Survey Report of Investigations No. 35, 237 p.

Choquette, A.F., 1988, Regionalization of peak discharges for streams in Kentucky: U.S. Geological Survey Water Resources Investigations Report 87-4209, 105 p.

Cleveland, W.S., 1979, Robust locally weighted regression and smoothing scatterplots: Journal of the American Statistical Association, v. 74, p. 829-836.

Cleveland, W.S., 1984, Graphs in scientific publications: Journal of the American Statistical Association, v. 38, p. 261-26.

Conner, Glen, 1982, Monthly, seasonal, and annual precipitation in Kentucky 1951-1980: Bowling Green, Ky., Western Kentucky University, Kentucky Climate Center Publication Number 25, 30 p.

Davis, R.W., 1979, Map showing low flows, average flows, and drainage areas in Kentucky River Area Development District, Kentucky: U.S. Geological Survey Miscellaneous Field Studies Map 865-H, 1 map.

Dempster, G.R., Jr., 1990, National water information system user's manual, v. 2. Chap. 3-Automated data processing system: U.S. Geological Survey Open-File Report 90-116, $321 \mathrm{p}$.

Downs, A.C., and Caldwell, W.E., 2007, Kentucky public water-supply withdrawals during 1995, 2000, and 2005: U.S. Geological Survey Open-File Report 2007-1209, 16 p.

Enfield, D.B., Mestas-Nunez, A.M., and Trimble, P.J., 2001, The Atlantic multidecadal oscillation and its relation to rainfall and river flows in the continental U.S.: Geophysical Research Letters, v. 28, no. 10, p. 2,077-2,080.

Freund, R.J., and Littell, R.C., 2000, SAS system for regression (3d ed.): Cary, N.C., SAS Institute Inc., 236 p.

Grundstein, A.J. and Bentley, M.L., 2001, A growing-season hydroclimatology, focusing on soil moisture deficits, for the Ohio Valley Region: American Meteorological Society Journal of Hydrometeorology, v. 2, August 2001, p. 345355.

Hardison, C.H., 1971, Prediction error of regression estimates of streamflow characteristics at ungaged sites: U.S. Geological Survey Professional Paper 750-C, 9 p. 
Helsel, D.R., and Hirsch, R.M., 2002, Statistical methods in water resources: U.S. Geological Survey Techniques of Water-Resources Investigations, book 4, chap. A3, 510 p.

Hendricks, E.L., 1964, Compilation of records of surface waters of the United States, October 1950 to September 1960_-Part 3A, Ohio River Basin except Cumberland and Tennessee River Basins: U.S. Geological Survey WaterSupply Paper 1725, 560 p.

Hill, J.D., 2005, Kentucky weather: Lexington Kentucky, University Press of Kentucky, 196 p.

Hirsch, R.M., Slack, J.R., and Smith, R.A., 1982, Techniques of trend analysis for monthly water quality data: Water Resources Research, v. 18, no. 1, p. 107-121.

Hodgkins, G.A., and Martin, G.R., 2003, Estimating the magnitude of peak flows for streams in Kentucky for selected recurrence intervals: U.S. Geological Survey WaterResources Investigations Report 2003-4180, 73 p., 1 pl.

Hortness, J.E., 2006, Estimating low-flow frequency statistics for unregulated streams in Idaho: U.S. Geological Survey Scientific Investigations Report 2006-5035, 31 p.

Hosmer, D.W., and Lemeshow, S., 2000, Applied logistic regression: New York, Wiley, 373 p.

Interagency Advisory Committee on Water Data, 1982, Guidelines for determining flood flow frequency-Bulletin 17B of the Hydrology Subcommittee: U.S. Geological Survey, Office of Water-Data Coordination, $183 \mathrm{p}$.

Karl, T.R., and Knight., R.W., 1998, Secular trends of precipitation amount, frequency, and intensity in the USA: Bulletin of the American Meteorological Society, v. 79, p. 231-241.

Karl, T.R., Knight, R.W., Easterling, D.R., and Quayle, R.G., 1996, Indices of climate change for the United States: Bulletin of the American Meteorological Society, v. 77, no. 2, p. 279-292.

Kentucky Climate Center at Western Kentucky University, 2008a, Kentucky temperature monthly observations, available online at http://kyclim.wku.edu/tableData/observations/ KY_TEMP.htm. (Accessed April 4, 2008.)

Kentucky Climate Center at Western Kentucky University, 2008b, Kentucky precipitation monthly observations, available online at http://kyclim.wku.edu/tableData/observations/ KY_PRECIP.htm. (Accessed April 1, 2008.)

Kentucky Climate Center at Western Kentucky University, 2010, Climatography of Kentucky, available online at http://kyclim.wku.edu/climatography.htm. (Accessed May 19, 2010.)
Kentucky Geological Survey, 1980, Physiographic diagram of Kentucky: Lexington, Ky., University of Kentucky, 1 map [scale not specified].

Koltun, G.F., and Whitehead, M.T., 2002, Techniques for estimating selected streamflow characteristics of rural unregulated streams in Ohio: Water-Resources Investigations Report 02-4068, 50 p.

Lane, E.W., and Lei, Kai, 1950, Streamflow variability: Proceedings of the American Society of Civil Engineers, Transactions, v. 115, p. 1,084-1,134.

Lins, H.F., and Slack, J.R., 1999, Streamflow trends in the United States: Geophysical Research Letters, v. 26, no. 2, p. $227-230$.

Ludwig, A.H., and Tasker, G.D., 1993, Regionalization of low-flow characteristics of Arkansas streams: U.S. Geological Survey Water-Resources Investigations Report 93-4013, $19 \mathrm{p}$.

Lumb, A.M., Kittle, J.L., Jr., and Flynn, K.M., 1990, Users manual for ANNIE, a computer program for interactive hydrologic analyses and data management: U.S. Geological Survey Water-Resources Investigations Report 89-4080, 236 p.

Marquardt, D.W., 1970, Generalized inverses, ridge regression, biased linear estimation, and nonlinear estimation: Technometrics, v. 12, p. 591-612.

Martin, G.R., 2002, Estimating mean annual streamflow of rural streams in Kentucky: U.S. Geological Survey WaterResources Investigations Report 02-4206, 35 p.

Martin, G.R., and Ruhl, K.J., 1993, Regionalization of harmonic-mean streamflows in Kentucky: U.S. Geological Survey Water-Resources Investigations Report 92-4173, 47 p., 1 pl.

Mast, M.A., and Turk, J.T., 1999, Environmental characteristics and water quality of hydrologic benchmark network stations in the Eastern United States, 1963-95: U.S. Geological Survey Circular 1173-A, 158 p.

Mathsoft, Inc., 1999a, S-Plus 2000, Modern statistics and advanced graphics, Guide to statistics, Volume 1: Seattle, Wash., Data Analysis Products Division, 638 p.

Mathsoft, Inc., 1999b, S-Plus 2000, Modern statistics and advanced graphics, Guide to statistics, Volume 2: Seattle, Wash., Data Analysis Products Division, 582 p.

McCabe, G.J., Palecki, M.A., and Betancourt, J.L., 2004, Pacific and Atlantic Ocean influences on multidecadal drought frequency in the United States: Proceedings of the National Academy of Sciences of the USA, v. 101, no. 12, p. 4,136-4,141. 
McCabe, G.J., and Wolock, D.M., 2002, A step increase in streamflow in the conterminous United States: Geophysical Research Letters, v. 29, no. 24, 2185, doi:10.1029/2002GL015999.

McDowell, R.C., ed., 1986, The Geology of Kentucky-A text to accompany the geologic map of Kentucky: U.S. Geological Survey Professional Paper 1151-H, 76 p., 1 pl.

McFarland, A.C., 1950, Geology of Kentucky: Lexington, Ky., University of Kentucky, 531 p.

McGrain, Preston, and Currens, J.C., 1978, Topography of Kentucky: Lexington, Ky., University of Kentucky, Kentucky Geological Survey, series X, Special Publication 25, $76 \mathrm{p}$.

Melcher, N.B., and Ruhl, K.J., 1984, Streamflow and basin characteristics at selected sites in Kentucky: U.S. Geological Survey Open-File Report 84-704, 80 p.

Montgomery, D.C., and Peck, E.A., 1982, Introduction to linear regression analysis: New York, Wiley, 504 p.

National Research Council, 2006, Surface temperature reconstructions for the last 2,000 years: Washington, D.C., National Academy Press, $160 \mathrm{p}$.

Ohio River Valley Water Sanitation Commission, 2006, Pollution control standards for discharges to the Ohio River, 2006 revision-Appendix C, Critical flow values: Cincinnati, Ohio, ORSANCO, 58 p.

Ries, K.G., III, and Dillow, J.J.A., 2006, Magnitude and frequency of floods on nontidal streams in Delaware: U.S. Geological Survey Scientific Investigations Report 2006-5146, 59 p.

Riggs, H.C., 1964, The base-flow recession curve as an indicator of ground water: Berkley, Calif., International Association of Scientific Hydrology Publication 63, p. 352-363.

Riggs, H.C., 1972, Low-flow investigations: U.S. Geological Survey Techniques of Water-Resources Investigations, book 4, chap. B1, $18 \mathrm{p}$.

Ruhl, K.J., Burns, R.J., Martin, G.R., and Allgeier, D.P., 1995, Flow duration of Kentucky streams through 1990-Historical and monthly flow characteristics, including the effects of reservoirs: U.S. Geological Survey Open-File Report 95-353, $291 \mathrm{p}$.

Ruhl, K.J., and Martin, G.R., 1991, Low-flow characteristics of Kentucky streams: U.S. Geological Survey Water Resources Investigations Report 91-4097, 50 p.

SAS Institute, Inc., 1985, SAS User's Guide-Statistics: Cary, N.C., SAS Institute Inc., 956 p.
SAS Institute, Inc., 1995, Logistic regression examples using the SAS system (1st ed.), ver. 6: Cary, N.C., SAS Institute, Inc., $163 \mathrm{p}$.

SAS Institute, Inc., 2004, SAS OnlineDoc ${ }^{\circledR}$ 9.1.2: Cary, N.C., SAS Institute Inc.

Searcy, J.K., 1959, Flow-duration curves: U.S. Geological Survey Water-Supply Paper 1542-A, p. 1-33.

Searcy, J.K., Hardison, C.H., and Langein, W.B., 1960, Double-mass curves; with a section on Fitting curves to cyclic data: U.S. Geological Survey Water-Supply Paper 1541-B, p. 31-66.

Slack, J.R., and Landwehr, J.M., 1992, Hydro-climatic data network (HCDN) - A U.S. Geological Survey streamflow dataset for the United States for the study of climate variations, 1874-1988: U.S. Geological Survey Open-File Report 92-129, 193 p.

Solomon, Susan; Qin, Dahe; Manning, Martin; Marquis, Melinda; Averyt, Kristen; Tignor, M.M.B.; and Miller, H.L., eds., 2007, Climate change 2007-The physical science basis - Contribution of working group I to the fourth assessment report of the Intergovernmental Panel on Climate Change: Cambridge, United Kingdom, and New York, N.Y., Cambridge University Press, 996 p.

Speer, P.R., Perry, W.J., McCabe, J.A., Lara, O.G., and Jeffery, H.G., 1965, Low-flow characteristics of streams in the Mississippi embayment in Tennessee, Kentucky, and Illinois, with a section on quality of the water: U.S. Geological Survey Professional Paper 448-H, 36 p.

Stedinger, J.R., and Thomas, W.O., Jr., 1985, Low-flow frequency estimation using base-flow measurements: U.S. Geological Survey Open-File Report 85-95, 22 p.

Stuckey, M.H., 2006, Low-flow, base-flow, and mean-flow regression equations for Pennsylvania streams: U.S. Geological Survey Scientific Investigations Report 2006-5130, $64 \mathrm{p}$.

Sullavan, J.N., 1980, Low-flow characteristics of Kentucky streams, 1980: U.S. Geological Survey Open-File Report 80-1225, 1 map, scale 1:500,000.

Sullavan, J.N., 1984, Low-flow characteristics of Kentucky streams, 1984: U.S. Geological Survey Open-File Report 84-705, 2 p., 1 map.

Swisshelm, R.V., Jr., 1974, Low-flow characteristics of Kentucky streams: U.S. Geological Survey Open-File Report 73-273, 1 map.

Tasker, G.D., 1980, Hydrologic regression with weighted least squares: Water Resources Research, v. 16, no. 6, p. 1,1071,113 . 
Tasker, G.D., 1987, A comparison of methods for estimating low flow characteristics of streams: Water Resources Bulletin, v. 23, no. 6, p. 1,077-1,083.

Tasker, G.D., 1989, Regionalization of low flow characteristics using logistic and GLS regression, in Kavvas, M.L., ed., New directions for surface water modeling: International Association of Hydrological Sciences Publication No. 181, p. 323-331.

Tasker, G.D., and Stedinger, J.R., 1989, An operational GLS model for hydrologic regression: Journal of Hydrology, v. 111 , p. 361-375.

Taylor, C.J., and Nelson, H.L., Jr., 2008, A compilation of provisional karst geospatial data for the Interior Low Plateaus physiographic region, central United States: U.S. Geological Survey Data Series 339, 26 p., available only online at http://pubs.usgs.gov/ds/339/.

Tennessee Department of Environment and Conservation, 2007, South Fork Cumberland River Watershed (05130104) of the Cumberland River Basin Watershed Water Quality Management Plan [variously paged], available online at http://www.state.tn.us/environment/wpc/watershed/ wsmplans/sfcumberland/. (Accessed January 6, 2009.)

Thomas, D.M., and Benson, M.A., 1970, Generalization of streamflow characteristics from drainage-basin characteristics: U.S. Geological Survey Water-Supply Paper 1975, $55 \mathrm{p}$.

U.S. Department of Agriculture-Natural Resources Conservation Service, 2007, Soil Survey Geographic (SSURGO) database for Kentucky (by county), available online at http://www.soils.usda.gov/survey/geography/ssurgo/. (Accessed January 27, 2010.)

U.S. Geological Survey, 1962-65, Surface water records of Kentucky, 1961-64: U.S. Geological Survey Water-Data Reports (published annually).

U.S. Geological Survey, 1964, Compilation of records of surface waters of the United States, October 1950 to September 1960 — Part 3B, Cumberland and Tennessee River Basins: U.S. Geological Survey Water-Supply Paper 1726, 269 p.
U.S. Geological Survey, 1966-75, Water resources data for Kentucky, 1965-74-part 1, Surface-water records: U.S. Geological Survey Water-Data Reports (published annually).

U.S. Geological Survey, 1976-2007, Water resources data for Kentucky, water years 1975-2006: U.S. Geological Survey WaterData Reports KY-75-1 to KY 06-1 (published annually).

U.S. Geological Survey, 2003, User's manual for the National Water Information System of the U.S. Geological SurveyAutomated Data Processing System (ADAPS), ver. 4.3: U.S. Geological Survey Open-File Report 2003-123, 413 p.

U.S. Geological Survey, 2005, Preliminary integrated Geologic Map Databases for the United States: Kentucky, Ohio, Tennessee, and West Virginia, digital data, available online at http://tin.er.usgs.gov/geology/state/state.php? state $=K Y$. (Accessed May 20, 2009.)

U.S. Geological Survey, 2007, National Land Cover Database 2001, available online at http://www.mrlc.gov. (Accessed January 27, 2010.)

Vogel, R.M., and Kroll, C.N., 1989, Low-flow frequency analysis using probability-plot correlation coefficients: Journal of Water Resources Planning and Management, v. 115, no. 3, p. 338-357.

Wells, J.V.B., 1957, Compilation of records of surface waters of the United States through September 1950-Part 3A, Ohio River Basin except Cumberland and Tennessee River Basins: U.S. Geological Survey Water-Supply Paper 1305, $652 \mathrm{p}$.

Wells, J.V.B., 1958, Compilation of records of surface waters of the United States through September 1950-Part 3B, Ohio River Basin, Cumberland and Tennessee River Basins: U.S. Geological Survey Water-Supply Paper 1306, 353 p.

Wetzel, K.L., and Bettandorff, J.M., 1986, Techniques for estimating streamflow characteristics in the Eastern and Interior coal provinces of the United States: U.S. Geological Survey Water-Supply Paper 2276, 80 p. 

Table 1. Description of streamflow-gaging stations evaluated for use in the low-flow regressions in Kentucky.

[Type, type of streamflow-gaging stations; --, not applicable; climate year, the 12-month period April 1-March 31 is identified by the year in which it ends; LD, local diversions; major STP, major sewage-treatment plants upstream (major defined as 1 million gallons per day or more; P, low-flow, partial-record station; KY, Kentucky; W, withdrawal; D, discharge; W1,D1, one withdrawal and one discharge in basin--zero and up are the number of withdrawals and discharges; C, long-term, continuous-record station; period of record for partial-record stations indicates years in which low-flow measurements were made]

\begin{tabular}{|c|c|c|c|c|c|}
\hline \multirow{2}{*}{ Station number } & \multirow{2}{*}{ Type } & \multirow{2}{*}{ Station name } & \multirow{2}{*}{$\begin{array}{c}\text { Total } \\
\text { drainage } \\
\text { area }\end{array}$} & \multicolumn{2}{|c|}{$\begin{array}{l}\text { Period of record } \\
\text { (climate years) }\end{array}$} \\
\hline & & & & Unregulated & $\begin{array}{c}\text { Homogeneous } \\
\text { unregulated }\end{array}$ \\
\hline $03207915^{1}$ & $\mathrm{C}$ & Elkfoot Branch, Levisa Fork, KY & 0.04 & $1981-85$ & $1981-85$ \\
\hline 03207965 & $\mathrm{C}$ & Grapevine Creek near Phyllis, KY & 6.49 & $\begin{array}{l}1975-82,1991-92 \\
1996-2006\end{array}$ & $\begin{array}{l}1975-82 \\
1991-92\end{array}$ \\
\hline 03208000 & $\mathrm{C}$ & $\begin{array}{l}\text { Levisa Fork below Fishtrap Dam near } \\
\text { Millard, KY }\end{array}$ & 391 & $1939-68$ & $1939-68$ \\
\hline $03209440^{1}$ & $\mathrm{C}$ & Shelby Creek at Dorton, KY & 12.4 & $1973-77$ & $1973-77$ \\
\hline 03209500 & $\mathrm{C}$ & Levisa Fork at Pikeville, KY & 1,230 & $1939-63$ & $1939-63$ \\
\hline 03210000 & $\mathrm{C}$ & Johns Creek near Meta, KY & 56.4 & $1942-93,1996-2006$ & $1942-75$ \\
\hline 03211500 & $\mathrm{C}$ & Johns Creek near Van Lear, KY & 206 & $1941-50$ & $1941-50$ \\
\hline 03212000 & $\mathrm{C}$ & Paint Creek at Staffordville, KY & 103 & $1951-75$ & $1951-68$ \\
\hline 03215500 & $\mathrm{C}$ & Blaine Creek at Yatesville, KY & 217 & $1917-18,1939-75$ & $\begin{array}{l}1917-18 \\
1939-75\end{array}$ \\
\hline 03216500 & $\mathrm{C}$ & Little Sandy River at Grayson, KY & 400 & $1939-68$ & $1939-68$ \\
\hline 03216540 & $\mathrm{C}$ & $\begin{array}{l}\text { East Fork Little Sandy River near } \\
\text { Fallsburg, KY }\end{array}$ & 12.4 & 1974-91 & 1974-91 \\
\hline 03216800 & $\mathrm{C}$ & Tygarts Creek at Olive Hill, KY & 59.4 & $1958-94$ & $1958-67$ \\
\hline 03217000 & $\mathrm{C}$ & Tygarts Creek near Greenup, KY & 242 & $1942-2006$ & $1942-67$ \\
\hline $03237255^{2}$ & $\mathrm{C}$ & $\begin{array}{l}\text { Kinniconick Creek below Trace Creek } \\
\text { at Tannery, KY }\end{array}$ & 214 & $1993-2006$ & $1993-2003$ \\
\hline 03237900 & $\mathrm{C}$ & Cabin Creek at Tollesboro, $\mathrm{KY}$ & 21.9 & $1973-92$ & 1973-92 \\
\hline 03248500 & $\mathrm{C}$ & Licking River near Salyersville, KY & 140 & $1940-92,1996-97$ & $1940-75$ \\
\hline 03249500 & $\mathrm{C}$ & Licking River at Farmers, KY & 827 & $1929-73$ & $1929-73$ \\
\hline 03250000 & $\mathrm{C}$ & Triplett Creek at Morehead, KY & 47.7 & $1943-80,1990-92$ & $1943-59$ \\
\hline 03250100 & $\mathrm{C}$ & $\begin{array}{l}\text { North Fork Triplett Creek near } \\
\text { Morehead, KY }\end{array}$ & 84.7 & 1969-94 & 1969-94 \\
\hline 03250500 & $\mathrm{C}$ & $\begin{array}{l}\text { Licking River Near Blue Lick } \\
\text { Springs, KY }\end{array}$ & 1,785 & $1939-59$ & $1939-59$ \\
\hline 03251000 & $\mathrm{C}$ & $\begin{array}{l}\text { North Fork Licking River near } \\
\text { Lewisburg, KY }\end{array}$ & 119 & $1948-91$ & $1948-63$ \\
\hline 03252500 & $\mathrm{C}$ & $\begin{array}{l}\text { South Fork Licking River at } \\
\text { Cynthiana, KY }\end{array}$ & 621 & $1939-94$ & -- \\
\hline 03254400 & $\mathrm{C}$ & North Fork Grassy Creek near Piner, KY & 13.6 & $1969-83$ & $1969-83$ \\
\hline $03277355^{1}$ & $\mathrm{P}$ & Camp Creek near Polly, Ky & 6.3 & $1988,1992,2005$ & $\begin{array}{l}1988,1992 \\
2005\end{array}$ \\
\hline 03277400 & $\mathrm{C}$ & Leatherwood Creek at Daisy, KY & 40.9 & $1966-74,1993-98$ & $1966-74$ \\
\hline 03277450 & $\mathrm{C}$ & Carr Fork near Sassafras, KY & 60.5 & $1965-75$ & $1965-75$ \\
\hline 03277500 & $\mathrm{C}$ & $\begin{array}{l}\text { North Fork Kentucky River at } \\
\text { Hazard, KY }\end{array}$ & 465 & $1941-75$ & $1941-75$ \\
\hline 03278000 & $\mathrm{C}$ & Bear Branch near Noble, KY & 2.21 & $1956-73$ & $1956-73$ \\
\hline 03278500 & $\mathrm{C}$ & Troublesome Creek at Noble, KY & 177 & $1951-81$ & $1951-65$ \\
\hline
\end{tabular}




\begin{tabular}{|c|c|c|c|c|}
\hline $\begin{array}{c}\begin{array}{c}\text { Period of record } \\
\text { (climate years) }\end{array} \\
\text { Regulated }\end{array}$ & $\begin{array}{c}\text { Local } \\
\text { diversions }\end{array}$ & $\begin{array}{l}\text { Number of } \\
\text { major STPs }\end{array}$ & Source of regulation and start date & Remarks \\
\hline-- & W0,D0 & 0 & -- & -- \\
\hline-- & W0,D2 & 0 & -- & -- \\
\hline 1970-92 & W2,D7 & 0 & Fishtrap Lake, 10/68 & -- \\
\hline-- & W0, D3 & 0 & -- & -- \\
\hline $1970-2006$ & W20,D59 & 0 & $\begin{array}{l}\text { Flannagan Lake, 12/63; North Fork Pound } \\
\text { Lake, 08/66; Fishtrap Lake, 10/68 }\end{array}$ & -- \\
\hline-- & W4, D7 & 0 & -- & Highly trended after 1975 \\
\hline 1952-92 & W4, D7 & 0 & Dewey Lake, $05 / 50$ & -- \\
\hline-- & W0,D3 & 0 & -- & -- \\
\hline-- & W0,D4 & 0 & Yatesville Lake, 05/1992 & -- \\
\hline $1969-2006$ & W3,D14 & 0 & Grayson Lake, 03/68 & -- \\
\hline-- & W0,D0 & 0 & -- & -- \\
\hline -- & W2,D1 & 0 & -- & -- \\
\hline-- & W3,D9 & 0 & -- & -- \\
\hline-- & W0,D0 & 0 & -- & -- \\
\hline-- & W0,D2 & 0 & -- & -- \\
\hline-- & W1,D5 & 0 & -- & -- \\
\hline $1975-1994$ & W5,D24 & 0 & Cave Run Lake, 12/73 & Highly trended after 1973 \\
\hline-- & W1,D0 & 0 & -- & -- \\
\hline-- & W0,D2 & 0 & -- & -- \\
\hline 2003-06 & W16,D61 & 2 & Cave Run Lake, 12/73 & -- \\
\hline-- & W0,D4 & 0 & -- & -- \\
\hline -- & W7,D43 & 4 & -- & Not used; LD \\
\hline -- & W0,D0 & 0 & -- & -- \\
\hline -- & W0,D0 & 0 & -- & -- \\
\hline-- & W5,D1 & 0 & -- & Not used, under 10 years \\
\hline 1977-94 & W0,D3 & 0 & Carr Fork Lake, 01/76 & Highly trended after 1975 \\
\hline 1977-92 & W29,D33 & 0 & Carr Fork Lake, 01/76 & -- \\
\hline -- & W0,D0 & 0 & -- & -- \\
\hline -- & W2,D10 & 0 & -- & -- \\
\hline
\end{tabular}


Table 1. Description of streamflow-gaging stations evaluated for use in the low-flow regressions in Kentucky. - Continued

[Type, type of streamflow-gaging stations; --, not applicable; climate year, the 12-month period April 1-March 31 is identified by the year in which it ends; LD, local diversions; major STP, major sewage-treatment plants upstream (major defined as 1 million gallons per day or more; P, low-flow, partial-record station; KY, Kentucky; W, withdrawal; D, discharge; W1,D1, one withdrawal and one discharge in basin--zero and up are the number of withdrawals and discharges; C, long-term, continuous-record station; period of record for partial-record stations indicates years in which low-flow measurements were made]

\begin{tabular}{|c|c|c|c|c|c|}
\hline \multirow{2}{*}{ Station number } & \multirow{2}{*}{ Type } & \multirow{2}{*}{ Station name } & \multirow{2}{*}{$\begin{array}{l}\text { Total } \\
\text { drainage } \\
\text { area }\end{array}$} & \multicolumn{2}{|c|}{$\begin{array}{l}\text { Period of record } \\
\text { (climate years) }\end{array}$} \\
\hline & & & & Unregulated & $\begin{array}{c}\text { Homogeneous } \\
\text { unregulated }\end{array}$ \\
\hline 03280000 & $\mathrm{C}$ & $\begin{array}{l}\text { North Fork Kentucky River at } \\
\text { Jackson, KY }\end{array}$ & 1,101 & $1930-31,1939-75$ & $\begin{array}{l}1930-31 \\
1939-75\end{array}$ \\
\hline 03280600 & $\mathrm{C}$ & $\begin{array}{l}\text { Middle Fork Kentucky River near } \\
\text { Hyden, KY }\end{array}$ & 202 & $1959-92$ & $1959-68$ \\
\hline $03280680^{1}$ & $\mathrm{P}$ & Wolf Creek at Cinda, Ky & 9.89 & 1988-89, 1992, 2006 & $\begin{array}{l}1988-89,1992 \\
2006\end{array}$ \\
\hline 03280700 & $\mathrm{C}$ & Cutshin Creek at Wooton, KY & 61.1 & $1959-2006$ & $1959-89$ \\
\hline 03280900 & $\mathrm{C}$ & $\begin{array}{l}\text { Middle Fork Kentucky River at } \\
\text { Buckhorn, KY }\end{array}$ & 420 & $1958-60$ & $1958-60$ \\
\hline 03281000 & $\mathrm{C}$ & $\begin{array}{l}\text { Middle Fork Kentucky River at } \\
\text { Tallega, KY }\end{array}$ & 536 & $1932,1941-60$ & $1932,1941-60$ \\
\hline 03281040 & $\mathrm{C}$ & Red Bird River near Big Creek, KY & 155 & $1974-2000$ & $1974-89$ \\
\hline 03281100 & $\mathrm{C}$ & Goose Creek at Manchester, KY & 163 & $1966-2006$ & $1966-89$ \\
\hline 03281500 & $\mathrm{C}$ & $\begin{array}{l}\text { South Fork Kentucky River at } \\
\text { Booneville, KY }\end{array}$ & 722 & $1926-31,1941-2006$ & $\begin{array}{l}\text { 1926-31 } \\
1941-66\end{array}$ \\
\hline 03282040 & $\mathrm{C}$ & Sturgeon Creek at Cressmmont, KY & 77.4 & 1994-2006 & 1994-2006 \\
\hline 03282500 & $\mathrm{C}$ & Red River near Hazel Green, KY & 65.9 & $1955-2006$ & $1955-71$ \\
\hline 03283000 & $\mathrm{C}$ & Stillwater Creek at Stillwater, KY & 24.0 & $1955-73$ & $1955-73$ \\
\hline 03283500 & $\mathrm{C}$ & Red River at Clay City, KY & 362 & $1932,1939-2006$ & $1932,1939-60$ \\
\hline 03285000 & $\mathrm{C}$ & Dix River at Danville, KY & 317 & 1944-2006 & $1944-71$ \\
\hline 03288000 & $\mathrm{C}$ & $\begin{array}{l}\text { North Elkhorn Creek near } \\
\text { Georgetown, KY }\end{array}$ & 119 & 1951-84, 1990-1999 & $1951-74$ \\
\hline 03288500 & $\mathrm{C}$ & Cave Creek near Fort Spring, KY & 2.31 & $1954-72$ & $1954-72$ \\
\hline 03289000 & $\mathrm{C}$ & South Elkhorn Creek at Fort Spring, KY & 23.9 & $1951-92,1999-2006$ & $1951-74$ \\
\hline 03289500 & $\mathrm{C}$ & Elkhorn Creek near Frankfort, KY & 473 & $\begin{array}{l}1917-18,1941-84 \\
1989-2006\end{array}$ & -- \\
\hline 03290000 & $\mathrm{C}$ & Flat Creek near Frankfort, KY & 5.65 & $1953-71$ & $1953-71$ \\
\hline 03291000 & $\mathrm{C}$ & Eagle Creek at Sadieville, KY & 41.5 & $1943-75$ & $1943-75$ \\
\hline 03291500 & $\mathrm{C}$ & Eagle Creek at Glencoe, KY & 437 & $\begin{array}{l}\text { 1917-18, 1930-31, } \\
1940-77 \\
1990-2006\end{array}$ & $\begin{array}{l}1917-18, \\
1930-31 \\
1940-71\end{array}$ \\
\hline 03292500 & $\mathrm{C}$ & $\begin{array}{l}\text { South Fork Beargrass Creek at } \\
\text { Louisville, KY }\end{array}$ & 17.2 & $\begin{array}{l}1946-53,1956-62 \\
1972-83,1990-2006\end{array}$ & -- \\
\hline 03293000 & $\mathrm{C}$ & $\begin{array}{l}\text { Middle Fork Beargrass Creek at } \\
\text { Old Cannons Lane, Louisville, KY }\end{array}$ & 18.9 & $1946-2006$ & -- \\
\hline 03295000 & $\mathrm{C}$ & Salt River near Harrodsburg, KY & 41.9 & $1954-73$ & $1954-73$ \\
\hline 03295500 & $\mathrm{C}$ & Salt River near Van Buren, KY & 196 & $1940-82$ & $1940-67$ \\
\hline 03298000 & $\mathrm{C}$ & Floyds Fork at Fisherville, KY & 138 & $1946-2006$ & $1946-75$ \\
\hline 03298500 & $\mathrm{C}$ & Salt River at Shepherdsville, KY & 1,196 & $1940-82$ & $1940-67$ \\
\hline 03299000 & $\mathrm{C}$ & Rolling Fork near Lebanon, KY & 239 & 1939-92 & $1939-65$ \\
\hline 03300000 & $\mathrm{C}$ & Beech Fork near Springfield, KY & 86.0 & $1954-72$ & $1954-72$ \\
\hline 03300400 & $\mathrm{C}$ & Beech Fork at Maud, KY & 436 & $1974-2006$ & $1974-80$ \\
\hline
\end{tabular}


Period of record

(climate years)

Regulated
1977-2006

$--$

--

--

1962-75

1962-2006

$-$

--

--

$-$

$-$

$-$

$-$

$--$

$-$

$-$

$-$

$-$

$-$

$--$

$-$

$-$

1984-2006

--

--

$-$

$\begin{array}{cccc}\begin{array}{c}\text { Local } \\ \text { diversions }\end{array} & \begin{array}{c}\text { Number of } \\ \text { major STPs }\end{array} & \text { Source of regulation and start date } & \text { Remarks }\end{array}$

Carr Fork Lake, 01/76

W37, D63 $1 \quad$ Carr Fork Lake, 01/76

W7,D5

W0,D0

W0,D1

W8,D17

W8,D22

W0,D4

W0,D1

W5,D20

W0,D0

W0,D4

W0,D0

W3,D29

W1,D9

W0,D5

W0,D0

W0,D4

W14,D60

W0,D0

W0,D2

W2,D20

W0,D6

W2,D5

W0,D3

W2, D15

W7, D30

W18, D114

W3, D8

W0,D0

W1, D4
0

0

Buckhorn Lake, 12/60

Buckhorn Lake, 12/60

$-$

$--$

$-$

$--$

$-$

$-$

$--$

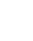

$-$

$--$

$--$

$--$

$--$

$-$

$--$

$-$

$--$
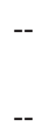

$-$

$-$

$-$

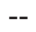

$--$

$--$

--

$-$

Not used, LD

$--$

$-$

$-$

Not used, urban

Not used, urban

$-$

$-$

$-$

$-$ 
Table 1. Description of streamflow-gaging stations evaluated for use in the low-flow regressions in Kentucky. —Continued

[Type, type of streamflow-gaging stations; --, not applicable; climate year, the 12-month period April 1-March 31 is identified by the year in which it ends; LD, local diversions; major STP, major sewage-treatment plants upstream (major defined as 1 million gallons per day or more; P, low-flow, partial-record station; KY, Kentucky; W, withdrawal; D, discharge; W1,D1, one withdrawal and one discharge in basin--zero and up are the number of withdrawals and discharges; C, long-term, continuous-record station; period of record for partial-record stations indicates years in which low-flow measurements were made]

\begin{tabular}{|c|c|c|c|c|c|}
\hline \multirow{2}{*}{ Station number } & \multirow{2}{*}{ Type } & \multirow{2}{*}{ Station name } & \multirow{2}{*}{$\begin{array}{l}\text { Total } \\
\text { drainage } \\
\text { area }\end{array}$} & \multicolumn{2}{|c|}{$\begin{array}{l}\text { Period of record } \\
\text { (climate years) }\end{array}$} \\
\hline & & & & Unregulated & $\begin{array}{c}\text { Homogeneous } \\
\text { unregulated }\end{array}$ \\
\hline 03301000 & $\mathrm{C}$ & Beech Fork at Bardstown, KY & 669 & $\begin{array}{l}\text { 1941-74, 1999, } \\
\text { 2002-2006 }\end{array}$ & $1941-62$ \\
\hline 03301500 & $\mathrm{C}$ & Rolling Fork near Boston, KY & 1,300 & $1940-2006$ & $1940-65$ \\
\hline $03302150^{1}$ & $\mathrm{P}$ & Doe Run near Brandenburg Station, KY & 36.9 & $\begin{array}{l}1960,1963-65 \\
1969-73\end{array}$ & $\begin{array}{l}1960,1963-65 \\
1969-73\end{array}$ \\
\hline 03304500 & $\mathrm{C}$ & McGills Creek near McKinney, KY & 2.16 & $1953-71$ & $1953-71$ \\
\hline 03305000 & $\mathrm{C}$ & Green River near McKinney, KY & 22.4 & $1953-73$ & $1953-73$ \\
\hline 03306000 & $\mathrm{C}$ & Green River near Campbellsville, KY & 682 & $1932,1965-68$ & $1932,1965-68$ \\
\hline 03306500 & $\mathrm{C}$ & Green River at Greensburg, KY & 736 & $1941-68$ & $1941-68$ \\
\hline 03307000 & $\mathrm{C}$ & Russell Creek near Columbia, KY & 179 & $1941-2006$ & $1941-80$ \\
\hline 03307100 & $\mathrm{C}$ & Russell Creek near Gresham, KY & 265 & $1966-75$ & $1966-75$ \\
\hline 03307500 & $\mathrm{C}$ & $\begin{array}{l}\text { South Fork Little Barren River at } \\
\text { Edmonton, KY }\end{array}$ & 18.3 & $1943-72$ & $1943-72$ \\
\hline 03308500 & $\mathrm{C}$ & Green River at Munfordville, KY & 1,681 & $\begin{array}{l}1916-22,1929-31 \\
1939-68\end{array}$ & $\begin{array}{c}1916-22 \\
1929-31 \\
1939-68\end{array}$ \\
\hline 03309000 & $\mathrm{C}$ & Green River at Mammoth Cave, KY & 1,984 & $1940-50$ & $1940-50$ \\
\hline $03309100^{1}$ & $\mathrm{P}$ & $\begin{array}{l}\text { Wet Prong Buffalo Creek near } \\
\text { Mammoth Cave, KY }\end{array}$ & 2.74 & $1963-75$ & $1963-75$ \\
\hline 03309500 & $\mathrm{C}$ & McDougal Creek near Hodgenville, KY & 5.28 & $1955-71$ & $1955-71$ \\
\hline 03310000 & $\mathrm{C}$ & $\begin{array}{l}\text { North Fork Nolin River at } \\
\text { Hodgenville, KY }\end{array}$ & 36.7 & $1943-73$ & $1943-73$ \\
\hline $03310078^{1}$ & $\mathrm{P}$ & South Fork Nolin River at Mathers Mill, & 50.1 & $\begin{array}{l}1975-79,1981-82 \\
1989\end{array}$ & $\begin{array}{l}1975-79 \\
1981-82 \\
1989\end{array}$ \\
\hline 03310300 & $\mathrm{C}$ & Nolin River at White Mills, KY & 360 & $1961-2006$ & -- \\
\hline 03310400 & $\mathrm{C}$ & Bacon Creek near Priceville, KY & 80.6 & $1961-94$ & $1961-94$ \\
\hline 03310500 & $\mathrm{C}$ & Nolin River at Wax, KY & 599 & $1938-62$ & $1938-47$ \\
\hline $03310600^{1}$ & $\mathrm{P}$ & Dog Creek near Mammoth Cave, Ky & 8.04 & $1962-75$ & $1962-75$ \\
\hline 03311000 & $\mathrm{C}$ & Nolin River at Kyrock, KY & 707 & $1932,1941-50,1962$ & $1932,1941-50$ \\
\hline $03311100^{1}$ & $\mathrm{P}$ & Bylew Creek Near Mammoth Cave, Ky & 5.11 & $1962-75$ & $1962-75$ \\
\hline 03311600 & $\mathrm{C}$ & Beaverdam Creek at Rhoda, KY & 10.9 & 1974-94 & 1974-94 \\
\hline 03312000 & $\mathrm{C}$ & Bear Creek near Leitchfield, KY & 30.8 & $1951-71$ & $1951-71$ \\
\hline 03312500 & $\mathrm{C}$ & Barren River near Pageville, KY & 532 & $1940-63$ & $1940-63$ \\
\hline 03312765 & $\mathrm{C}$ & $\begin{array}{l}\text { Beaver Creek at Highway } 31 \text { East } \\
\text { near Glasgow, KY }\end{array}$ & 47.1 & $1993-2002$ & $1993-2002$ \\
\hline 03313000 & $\mathrm{C}$ & Barren River near Finney, KY & 942 & $1943-50,1962-63$ & $\begin{array}{l}1943-50 \\
1962-63\end{array}$ \\
\hline 03313500 & $\mathrm{C}$ & West Bays Fork at Scottsville, KY & 7.46 & $1952-1972$ & $1952-67$ \\
\hline $03313700^{3}$ & $\mathrm{C}$ & $\begin{array}{l}\text { West Fork Drakes Creek near } \\
\text { Franklin, KY }\end{array}$ & 111 & $1970-89$ & $1970-79$ \\
\hline 03314000 & $\mathrm{C}$ & Drakes Creek near Alvaton, KY & 475 & $1942-71$ & $1942-71$ \\
\hline
\end{tabular}




\begin{tabular}{|c|c|c|c|c|}
\hline $\begin{array}{c}\begin{array}{c}\text { Period of record } \\
\text { (climate years) }\end{array} \\
\text { Regulated }\end{array}$ & $\begin{array}{c}\text { Local } \\
\text { diversions }\end{array}$ & $\begin{array}{l}\text { Number of } \\
\text { major STPs }\end{array}$ & Source of regulation and start date & Remarks \\
\hline-- & W5, D25 & 2 & -- & -- \\
\hline-- & W9, D44 & 3 & -- & -- \\
\hline-- & W0,D0 & 0 & -- & -- \\
\hline-- & W0,D0 & 0 & -- & -- \\
\hline-- & W1, D0 & 0 & -- & -- \\
\hline 1970-94 & W5, D9 & 0 & Green River Lake, 02/69 & -- \\
\hline 1970-75, 2006 & W6, D10 & 0 & -- & -- \\
\hline-- & W3, D6 & 0 & -- & -- \\
\hline-- & W3, D7 & 0 & -- & -- \\
\hline-- & W0,D0 & 0 & -- & -- \\
\hline 1970-2006 & W13, D40 & 1 & Green River Lake, 02/69 & -- \\
\hline 2005-06 & W14, D50 & 1 & -- & -- \\
\hline-- & W0,D0 & 0 & -- & -- \\
\hline-- & W0,D0 & 0 & -- & -- \\
\hline-- & W2, D1 & 0 & -- & -- \\
\hline-- & W0,D0 & 0 & -- & -- \\
\hline-- & W14, D23 & 1 & -- & Not used; LD \\
\hline-- & W1, D1 & 0 & -- & -- \\
\hline-- & W15, D24 & 1 & -- & -- \\
\hline-- & W0,D0 & 0 & -- & -- \\
\hline 1964-2004 & W17, D28 & 1 & Nolin Lake, 03/63 & -- \\
\hline-- & W0,D0 & 0 & -- & -- \\
\hline-- & W0,D0 & 0 & -- & -- \\
\hline-- & W0, D3 & 1 & -- & -- \\
\hline-- & W2, D8 & 0 & -- & -- \\
\hline-- & W0, D1 & 0 & -- & -- \\
\hline 1965-94 & W7, D20 & 1 & Barren River Lake, 03/64 & -- \\
\hline-- & W0,D0 & 0 & -- & -- \\
\hline 1990-2004 & W1, D1 & 0 & Concrete dam, raised and modified 1989 & -- \\
\hline-- & W2, D3 & 1 & -- & -- \\
\hline
\end{tabular}


Table 1. Description of streamflow-gaging stations evaluated for use in the low-flow regressions in Kentucky. - Continued

[Type, type of streamflow-gaging stations; --, not applicable; climate year, the 12-month period April 1-March 31 is identified by the year in which it ends; LD, local diversions; major STP, major sewage-treatment plants upstream (major defined as 1 million gallons per day or more; P, low-flow, partial-record station; KY, Kentucky; W, withdrawal; D, discharge; W1,D1, one withdrawal and one discharge in basin--zero and up are the number of withdrawals and discharges; C, long-term, continuous-record station; period of record for partial-record stations indicates years in which low-flow measurements were made]

\begin{tabular}{|c|c|c|c|c|c|}
\hline \multirow{2}{*}{ Station number } & \multirow{2}{*}{ Type } & \multirow{2}{*}{ Station name } & \multirow{2}{*}{$\begin{array}{l}\text { Total } \\
\text { drainage } \\
\text { area }\end{array}$} & \multicolumn{2}{|c|}{$\begin{array}{l}\text { Period of record } \\
\text { (climate years) }\end{array}$} \\
\hline & & & & Unregulated & $\begin{array}{c}\text { Homogeneous } \\
\text { unregulated }\end{array}$ \\
\hline 03314500 & $\mathrm{C}$ & Barren River at Bowling Green, KY & 1,846 & $1940-63$ & $1940-63$ \\
\hline 03316000 & $\mathrm{C}$ & Mud River near Lewisburg, KY & 90.7 & $1941-72$ & $1941-61$ \\
\hline 03317000 & $\mathrm{C}$ & Rough River near Madrid, KY & 225 & $1940-59$ & $1940-59$ \\
\hline 03317500 & $\mathrm{C}$ & $\begin{array}{l}\text { North Fork Rough River near } \\
\text { Westview, KY }\end{array}$ & 42.0 & $1955-73$ & $1955-73$ \\
\hline 03318000 & $\mathrm{C}$ & Rough River near Falls of Rough, KY & 454 & $1941-51$ & -- \\
\hline 03318200 & $\mathrm{C}$ & Rock Lick Creek near Glen Dean, KY & 20.1 & $1958-71$ & $1958-71$ \\
\hline 03318500 & $\mathrm{C}$ & Rough River at Falls of Rough, KY & 504 & $1950-59$ & -- \\
\hline 03318800 & $\mathrm{C}$ & Caney Creek near Horse Branch, KY & 117 & $1958-92$ & $1958-92$ \\
\hline 03319000 & $\mathrm{C}$ & Rough River near Dundee, KY & 757 & $1941-59$ & $1941-59$ \\
\hline 03320500 & $\mathrm{C}$ & Pond River near Apex, KY & 194 & $1942-2006$ & $1942-2006$ \\
\hline 03321350 & $\mathrm{C}$ & $\begin{array}{l}\text { South Fork Panther Creek near } \\
\text { Whitesville, KY }\end{array}$ & 58.2 & $1969-83$ & $1969-83$ \\
\hline 03322360 & $\mathrm{C}$ & Beaverdam Creek near Corydon, KY & 10.7 & $\begin{array}{l}1974-82,1985-86 \\
1989-94\end{array}$ & $\begin{array}{c}1974-82 \\
1985-86 \\
1989-94\end{array}$ \\
\hline 03383000 & $\mathrm{C}$ & Tradewater River at Olney, KY & 255 & $1942-84,1986-2006$ & $1942-75$ \\
\hline 03384000 & $\mathrm{C}$ & Rose Creek at Nebo, KY & 2.10 & $1953-70$ & $1953-70$ \\
\hline 03400500 & $\mathrm{C}$ & Poor Fork at Cumberland, KY & 82.1 & $1941-92$ & $1941-60$ \\
\hline $03400785^{1}$ & $\mathrm{C}$ & Martins Fork above Smith, KY & 23.7 & 1986-91 & 1986-91 \\
\hline 03400800 & $\mathrm{C}$ & Martins Fork near Smith, KY & 55.8 & $1972-78$ & $1972-78$ \\
\hline 03401000 & $\mathrm{C}$ & Cumberland River near Harlan, KY & 373 & $1941-78$ & $1941-78$ \\
\hline 03402000 & $\mathrm{C}$ & Yellow Creek near Middlesboro, KY & 60.6 & $1942-2005$ & -- \\
\hline $03402930^{1}$ & $\mathrm{P}$ & Fourmile Creek at Fourmile, Ky & 6.20 & $\begin{array}{l}1988-89,1991-92 \\
2006\end{array}$ & $\begin{array}{l}\text { 1988-89, } \\
1991-92 \\
2006\end{array}$ \\
\hline $03403000^{4}$ & $\mathrm{C}$ & Cumberland River near Pineville, KY & 809 & $1940-75$ & $1940-71$ \\
\hline 03403500 & $\mathrm{C}$ & Cumberland River at Barbourville, KY & 960 & $1924-31,1949-78$ & $\begin{array}{l}\text { 1924-31 } \\
1949-71\end{array}$ \\
\hline 03403910 & $\mathrm{C}$ & Clear Fork at Saxton, KY & 331 & $1970-90,1997-2004$ & $\begin{array}{l}1970-90 \\
1997-2004\end{array}$ \\
\hline 03404000 & $\mathrm{C}$ & Cumberland River at Williamsburg, KY & 1,607 & $1952-78$ & $1952-78$ \\
\hline 03404500 & $\mathrm{C}$ & $\begin{array}{l}\text { Cumberland River at Cumberland } \\
\text { Falls, KY }\end{array}$ & 1,976 & $\begin{array}{l}\text { 1909-11, 1916-31, } \\
\text { 1934-78 }\end{array}$ & $\begin{array}{c}1909-11 \\
1916-31 \\
1934-60\end{array}$ \\
\hline 03404900 & $\mathrm{C}$ & Lynn Camp Creek at Corbin, KY & 53.0 & $1975-2005$ & $1975-89$ \\
\hline 03405000 & $\mathrm{C}$ & Laurel River at Corbin, KY & 201 & $1924,1944-73$ & -- \\
\hline 03406000 & $\mathrm{C}$ & Wood Creek near London, KY & 3.90 & $1955-71$ & $1955-71$ \\
\hline 03406500 & $\mathrm{C}$ & Rockcastle River at Billows, KY & 604 & $1938-2006$ & $1938-90$ \\
\hline 03407100 & $\mathrm{C}$ & Cane Branch near Parkers Lake, KY & 0.65 & $1957-66$ & $1957-66$ \\
\hline 03407300 & $\mathrm{C}$ & Helton Branch at Greenwood, KY & 0.85 & $1957-74$ & $1957-74$ \\
\hline
\end{tabular}




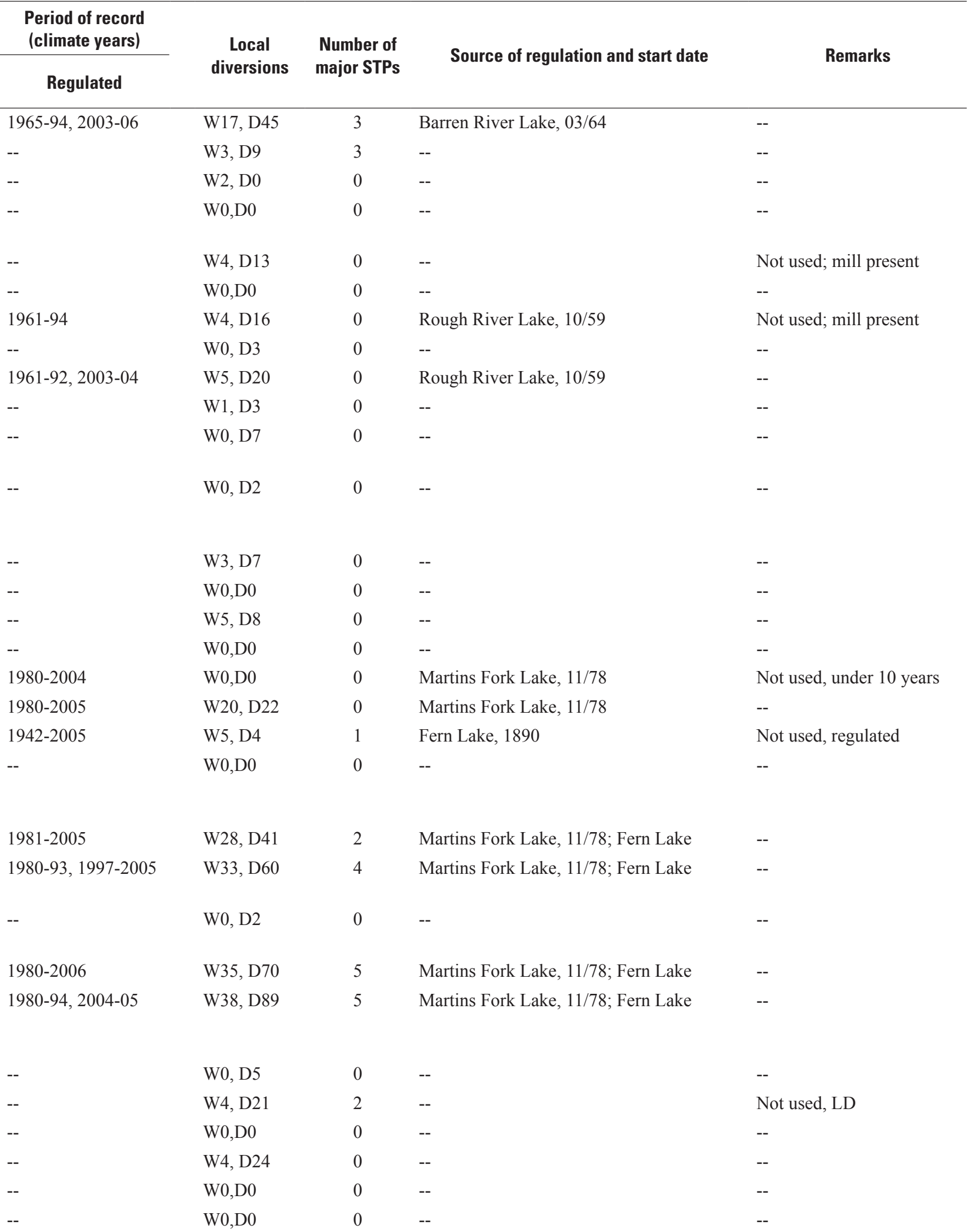


Table 1. Description of streamflow-gaging stations evaluated for use in the low-flow regressions in Kentucky. —Continued

[Type, type of streamflow-gaging stations; --, not applicable; climate year, the 12-month period April 1-March 31 is identified by the year in which it ends; LD, local diversions; major STP, major sewage-treatment plants upstream (major defined as 1 million gallons per day or more; P, low-flow, partial-record station; KY, Kentucky; W, withdrawal; D, discharge; W1,D1, one withdrawal and one discharge in basin--zero and up are the number of withdrawals and discharges; C, long-term, continuous-record station; period of record for partial-record stations indicates years in which low-flow measurements were made]

\begin{tabular}{|c|c|c|c|c|c|}
\hline \multirow{2}{*}{ Station number } & \multirow{2}{*}{ Type } & \multirow{2}{*}{ Station name } & \multirow{2}{*}{$\begin{array}{c}\text { Total } \\
\text { drainage } \\
\text { area }\end{array}$} & \multicolumn{2}{|c|}{$\begin{array}{l}\text { Period of record } \\
\text { (climate years) }\end{array}$} \\
\hline & & & & Unregulated & $\begin{array}{l}\text { Homogeneous } \\
\text { unregulated }\end{array}$ \\
\hline 03407500 & $\mathrm{C}$ & Buck Creek near Shopville, KY & 165 & 1954-91 & $1954-70$ \\
\hline 03410500 & $\mathrm{C}$ & $\begin{array}{l}\text { South Fork Cumberland River near } \\
\text { Stearns, KY }\end{array}$ & 954 & $1944-2005$ & $1944-2005$ \\
\hline 03411000 & $\mathrm{C}$ & $\begin{array}{l}\text { South Fork Cumberland River at } \\
\text { Nevelsville, KY }\end{array}$ & 1,267 & $1916-31,1934-50$ & $1916-31,1934-50$ \\
\hline 03412500 & $\mathrm{C}$ & Pitman Creek at Somerset, KY & 31.0 & $1955-72$ & $1955-72$ \\
\hline 03413200 & $\mathrm{C}$ & Beaver Creek near Monticello, KY & 43.2 & $1970-83,1991-2006$ & $1970-83,1991-95$ \\
\hline 03435140 & $\mathrm{C}$ & Whippoorwill Creek near Claymour, KY & 20.7 & $1975-91$ & $1975-91$ \\
\hline 03437500 & $\mathrm{C}$ & $\begin{array}{l}\text { South Fork Little River at } \\
\text { Hopkinsville, KY }\end{array}$ & 46.1 & $1951-73$ & $1951-60$ \\
\hline 03438000 & $\mathrm{C}$ & Little River near Cadiz, KY & 244 & $1941-2006$ & $1941-62$ \\
\hline 03438070 & $\mathrm{C}$ & $\begin{array}{l}\text { Muddy Fork Little River near } \\
\text { Cerulean, KY }\end{array}$ & 30.3 & $1970-83$ & $1970-83$ \\
\hline 03610000 & $\mathrm{C}$ & Clarks River at Murray, KY & 89.7 & $1953-71$ & -- \\
\hline 03610200 & $\mathrm{C}$ & Clarks River at Almo, KY & 134 & $1984-2006$ & -- \\
\hline 03610500 & $\mathrm{C}$ & Clarks River near Benton, KY & 227 & $1940-73$ & -- \\
\hline 03610545 & $\mathrm{C}$ & $\begin{array}{l}\text { West Fork Clarks River near } \\
\text { Brewers, KY }\end{array}$ & 68.3 & $1970-83,1990-94$ & $1970-83,1990-94$ \\
\hline 03611260 & $\mathrm{C}$ & Massac Creek near Paducah, KY & 10.4 & $1973-2006$ & 1973-93 \\
\hline 03611800 & $\mathrm{C}$ & Bayou Creek near Heath, KY & 6.55 & $1995-2006$ & $1995-2006$ \\
\hline 03611850 & $\mathrm{C}$ & Bayou Creek near Grahamville, KY & 14.9 & $1995-2006$ & -- \\
\hline 07022500 & $\mathrm{C}$ & Perry Creek near Mayfield, KY & 1.72 & $1954-66,1969-72$ & $1954-66,1969-72$ \\
\hline 07023000 & $\mathrm{C}$ & Mayfield Creek at Lovelaceville, KY & 212 & $1940-72$ & -- \\
\hline 07023500 & $\mathrm{C}$ & Obion Creek at Pryorsburg, KY & 37.0 & $1953-73$ & $1953-73$ \\
\hline 07024000 & $\mathrm{C}$ & Bayou De Chien near Clinton, KY & 68.7 & $1941-78,1986-2006$ & -- \\
\hline $07025440^{1}$ & $\mathrm{P}$ & Harris Fork Creek near Fulton, KY & 3.99 & $1988,1992,2006$ & $1988,1992,2006$ \\
\hline
\end{tabular}

${ }^{1}$ Low-flow, partial-record streamflow-gaging stations; or a long-term-continuous-record, streamflow-gaging station having less than 10 years record, which was treated as a low-flow, partial-record station..

${ }^{2}$ Combined records for stations 03237250 and 03237255.

${ }^{3}$ Station 03313700 had estimated 3 cubic feet per second withdrawal for water supply for the period 1977-79, which was added to the measured low flows prior to the frequency analysis.

${ }^{4}$ Combined records for stations 03402900 and 03403000. 


\begin{tabular}{|c|c|c|c|c|}
\hline $\begin{array}{c}\begin{array}{c}\text { Period of record } \\
\text { (climate years) }\end{array} \\
\text { Regulated }\end{array}$ & $\begin{array}{c}\text { Local } \\
\text { diversions }\end{array}$ & $\begin{array}{l}\text { Number of } \\
\text { major STPs }\end{array}$ & Source of regulation and start date & Remarks \\
\hline-- & W0, D5 & 0 & -- & -- \\
\hline-- & W1, D0 & 0 & -- & -- \\
\hline-- & W2, D1 & 0 & -- & -- \\
\hline-- & W1, D2 & 0 & -- & -- \\
\hline-- & W0,D0 & 0 & -- & -- \\
\hline-- & W0, D1 & 0 & -- & -- \\
\hline-- & W1, D1 & 0 & -- & -- \\
\hline-- & W6, D6 & 2 & -- & -- \\
\hline-- & W0,D0 & 0 & -- & -- \\
\hline-- & W0, D2 & 0 & -- & Not used; urbanized \\
\hline-- & W2, D8 & 1 & -- & Not used; highly trended \\
\hline-- & W3, D11 & 2 & -- & -- \\
\hline-- & W0,D0 & 0 & -- & -- \\
\hline-- & W0,D0 & 0 & -- & -- \\
\hline-- & W0,D0 & 0 & -- & -- \\
\hline-- & W0,D13 & 0 & -- & Not used; highly trended \\
\hline-- & W0,D0 & 0 & -- & -- \\
\hline-- & W8, D28 & 1 & -- & Not used; highly trended \\
\hline-- & W2, D1 & 0 & -- & -- \\
\hline-- & W0, D4 & 0 & -- & Not used; highly trended \\
\hline-- & W0,D0 & 0 & -- & -- \\
\hline
\end{tabular}


Table 2. Low-flow frequencies for streamflow-gaging stations used in the low-flow regressions in Kentucky.

$\left[\mathrm{mi}^{2}\right.$, square mile; $\mathrm{ft}^{3} / \mathrm{s}$, cubic foot per second; climate years, the 12-month period April 1--March 31 is identified by the year in which it ends; Regression: B, both the logistic regression and weighted-least-squares regression; KY, Kentucky; W, weighted-least-squares regression only; L, logistic regression only; period of record for the low-flow, partial-record stations indicates years in which low-flow measurements were made; --, not applicable]

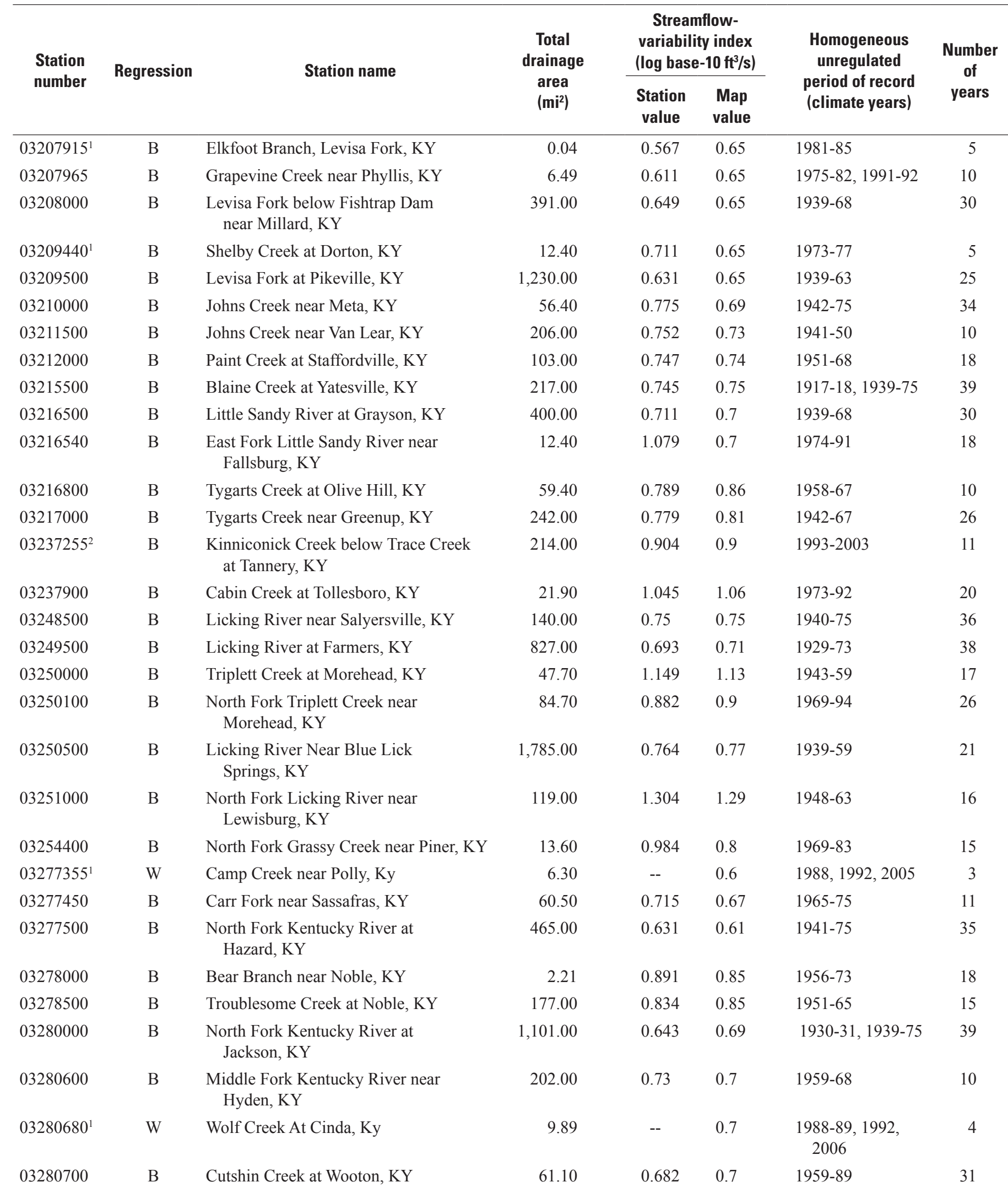




\begin{tabular}{|c|c|c|c|c|c|c|c|c|}
\hline & ynitude of & w-flow f & quency (ft & & \multicolumn{2}{|c|}{$\begin{array}{l}\text { Annual 7-day low } \\
\text { flow equal to zero }\end{array}$} & \multicolumn{2}{|c|}{$\begin{array}{l}\text { Annual 30-day low } \\
\text { flow equal to zero }\end{array}$} \\
\hline 2-year & 5-year & 2-year & 10-year & 20-year & Number & Frequency & Number & Frequency \\
\hline 0.053 & 0.02 & 0.039 & 0.009 & 0.006 & 0 & 0.00 & 0 & 0.00 \\
\hline 0.5 & 0.26 & 0.15 & 0.05 & 0.04 & 0 & 0.00 & 0 & 0.00 \\
\hline 17 & 5.49 & 8.71 & 1.3 & 0.67 & 0 & 0.00 & 0 & 0.00 \\
\hline 0.4 & 0.1 & 0.2 & 0.015 & 0.006 & 0 & 0.00 & 0 & 0.00 \\
\hline 50.8 & 18.7 & 25.6 & 4.97 & 2.93 & 0 & 0.00 & 0 & 0.00 \\
\hline 1.62 & 0.21 & 0.26 & 0 & 0 & 8 & 0.24 & 3 & 0.09 \\
\hline 3.34 & 1.1 & 1.65 & 0.36 & 0.21 & 0 & 0.00 & 0 & 0.00 \\
\hline 3.25 & 1.3 & 1.36 & 0.11 & 0 & 1 & 0.06 & 0 & 0.00 \\
\hline 5.09 & 2.22 & 2.69 & 0.53 & 0.31 & 0 & 0.00 & 0 & 0.00 \\
\hline 11.6 & 6.19 & 7.13 & 2.88 & 2.25 & 0 & 0.00 & 0 & 0.00 \\
\hline 0.08 & 0 & 0 & 0 & 0 & 9 & 0.50 & 3 & 0.17 \\
\hline 1.17 & 0.22 & 0.68 & 0 & 0 & 1 & 0.10 & 0 & 0.00 \\
\hline 4.47 & 1.58 & 1.87 & 0.27 & 0.1 & 1 & 0.04 & 0 & 0.00 \\
\hline 1.88 & 0.56 & 0.65 & 0.07 & 0 & 1 & 0.09 & 1 & 0.09 \\
\hline 0.16 & 0.02 & 0.01 & 0 & 0 & 9 & 0.45 & 2 & 0.10 \\
\hline 2.65 & 0.69 & 1.34 & 0 & 0 & 5 & 0.14 & 0 & 0.00 \\
\hline 30.2 & 11.8 & 19 & 4.1 & 2.53 & 0 & 0.00 & 0 & 0.00 \\
\hline 0.28 & 0.02 & 0.03 & 0 & 0 & 8 & 0.47 & 1 & 0.06 \\
\hline 1.37 & 0.15 & 0.22 & 0 & 0 & 3 & 0.12 & 0 & 0.00 \\
\hline 35.8 & 15 & 22.8 & 6.12 & 4.33 & 0 & 0.00 & 0 & 0.00 \\
\hline 0.14 & 0.01 & 0 & 0 & 0 & 10 & 0.63 & 3 & 0.19 \\
\hline 0.127 & 0.028 & 0 & 0 & 0 & 8 & 0.53 & 1 & 0.07 \\
\hline 1.3 & 1 & 1.1 & 0.8 & 0.7 & -- & -- & -- & -- \\
\hline 2.33 & 0.72 & 0.75 & 0.03 & 0.01 & 0 & 0.00 & 0 & 0.00 \\
\hline 22.3 & 10.5 & 8.8 & 2.14 & 1.41 & 0 & 0.00 & 0 & 0.00 \\
\hline 0.03 & 0.01 & 0.01 & 0 & 0 & 8 & 0.44 & 3 & 0.17 \\
\hline 3.16 & 0.47 & 0.79 & 0 & 0 & 2 & 0.13 & 1 & 0.07 \\
\hline 50.4 & 17.6 & 24.1 & 3.07 & 1.46 & 0 & 0.00 & 0 & 0.00 \\
\hline 6.65 & 2.26 & 1.42 & 0.24 & 0.15 & 0 & 0.00 & 0 & 0.00 \\
\hline 0.1 & 0.035 & 0.1 & 0.011 & 0.007 & -- & -- & -- & -- \\
\hline 2.92 & 1.2 & 0.82 & 0.11 & 0.06 & 0 & 0.00 & 0 & 0.00 \\
\hline
\end{tabular}


Table 2. Low-flow frequencies for streamflow-gaging stations used in the low-flow regressions in Kentucky-Continued

$\left[\mathrm{mi}^{2}\right.$, square mile; $\mathrm{ft} / \mathrm{s}$, cubic foot per second; climate years, the 12-month period April 1--March 31 is identified by the year in which it ends; Regression: B, both the logistic regression and weighted-least-squares regression; KY, Kentucky; W, weighted-least-squares regression only; L, logistic regression only; period of record for the low-flow, partial-record stations indicates years in which low-flow measurements were made; --, not applicable]

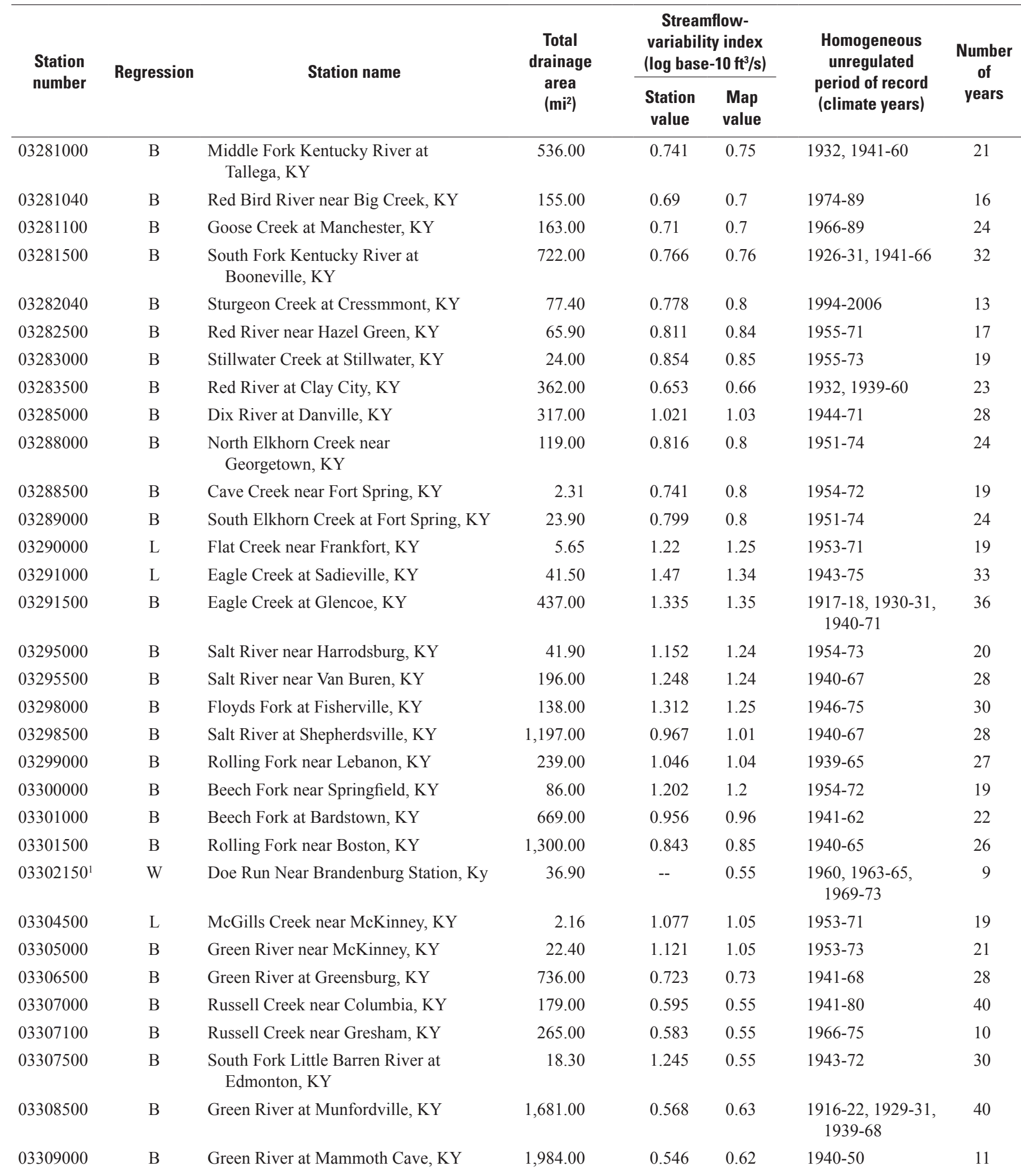




\begin{tabular}{|c|c|c|c|c|c|c|c|c|}
\hline \multicolumn{5}{|c|}{ Magnitude of low-flow frequency $\left(\mathrm{ft}^{3} / \mathrm{s}\right)$} & \multirow{2}{*}{\multicolumn{2}{|c|}{$\begin{array}{l}\text { Annual 7-day low } \\
\text { flow equal to zero }\end{array}$}} & \multirow{2}{*}{\multicolumn{2}{|c|}{$\begin{array}{l}\text { Annual 30-day low } \\
\text { flow equal to zero }\end{array}$}} \\
\hline \multirow{2}{*}{$\begin{array}{l}\text { 30-day, } \\
\text { 2-year }\end{array}$} & \multirow{2}{*}{$\begin{array}{l}\text { 30-day, } \\
5 \text {-year }\end{array}$} & \multirow{2}{*}{$\begin{array}{l}\text { 7-day, } \\
\text { 2-year }\end{array}$} & \multirow{2}{*}{$\begin{array}{l}\text { 7-day, } \\
\text { 10-year }\end{array}$} & \multirow{2}{*}{$\begin{array}{l}\text { 7-day, } \\
\text { 20-year }\end{array}$} & & & & \\
\hline & & & & & Number & Frequency & Number & Frequency \\
\hline 15.7 & 4.18 & 6.07 & 0.64 & 0.31 & 0 & 0.00 & 0 & 0.00 \\
\hline 5.86 & 2.6 & 1.86 & 0.66 & 0.51 & 0 & 0.00 & 0 & 0.00 \\
\hline 4.84 & 2.41 & 2.44 & 0.53 & 0.3 & 0 & 0.00 & 0 & 0.00 \\
\hline 18.6 & 3.25 & 6.91 & 0.44 & 0.11 & 1 & 0.03 & 0 & 0.00 \\
\hline 3.52 & 0.15 & 0.78 & 0 & 0 & 2 & 0.15 & 1 & 0.08 \\
\hline 0.79 & 0.3 & 0.13 & 0 & 0 & 4 & 0.24 & 0 & 0.00 \\
\hline 0.23 & 0.09 & 0.08 & 0 & 0 & 6 & 0.32 & 0 & 0.00 \\
\hline 16.4 & 8.56 & 9.73 & 3.29 & 2.5 & 0 & 0.00 & 0 & 0.00 \\
\hline 0.94 & 0.14 & 0.23 & 0 & 0 & 5 & 0.18 & 2 & 0.07 \\
\hline 1.77 & 0.58 & 1.06 & 0 & 0 & 3 & 0.13 & 1 & 0.04 \\
\hline 0.07 & 0.03 & 0.05 & 0 & 0 & 4 & 0.21 & 0 & 0.00 \\
\hline 0.52 & 0.06 & 0.47 & 0 & 0 & 9 & 0.38 & 1 & 0.04 \\
\hline 0 & 0 & 0 & 0 & 0 & 19 & 1.00 & 13 & 0.68 \\
\hline 0 & 0 & 0 & 0 & 0 & 27 & 0.82 & 18 & 0.55 \\
\hline 0.61 & 0.03 & 0.05 & 0 & 0 & 16 & 0.44 & 5 & 0.14 \\
\hline 0.1 & 0.03 & 0 & 0 & 0 & 10 & 0.50 & 2 & 0.10 \\
\hline 0.69 & 0 & 0 & 0 & 0 & 16 & 0.57 & 6 & 0.21 \\
\hline 0.16 & 0 & 0 & 0 & 0 & 16 & 0.53 & 8 & 0.27 \\
\hline 5.82 & 1.04 & 0.9 & 0 & 0 & 3 & 0.11 & 1 & 0.04 \\
\hline 1.05 & 0.12 & 0.18 & 0 & 0 & 8 & 0.30 & 3 & 0.11 \\
\hline 0.28 & 0.04 & 0 & 0 & 0 & 10 & 0.53 & 2 & 0.11 \\
\hline 3 & 0.77 & 1.19 & 0.12 & 0.06 & 0 & 0.00 & 0 & 0.00 \\
\hline 15 & 4.5 & 8.04 & 1.51 & 0.93 & 0 & 0.00 & 0 & 0.00 \\
\hline 8.6 & 6.4 & 7.9 & 5.1 & 4.5 & -- & -- & -- & -- \\
\hline 0 & 0 & 0 & 0 & 0 & 16 & 0.84 & 13 & 0.68 \\
\hline 0.09 & 0 & 0.01 & 0 & 0 & 10 & 0.48 & 5 & 0.24 \\
\hline 19.4 & 6.51 & 9.31 & 1.94 & 1.25 & 0 & 0.00 & 0 & 0.00 \\
\hline 14.7 & 6.68 & 7.48 & 2 & 1.32 & 0 & 0.00 & 0 & 0.00 \\
\hline 22.8 & 13.4 & 13.8 & 6.27 & 5 & 0 & 0.00 & 0 & 0.00 \\
\hline 0.05 & 0 & 0 & 0 & 0 & 23 & 0.77 & 12 & 0.40 \\
\hline 151 & 101 & 114 & 69.9 & 63 & 0 & 0.00 & 0 & 0.00 \\
\hline 174 & 137 & 139 & 105 & 99.2 & 0 & 0.00 & 0 & 0.00 \\
\hline
\end{tabular}


Table 2. Low-flow frequencies for streamflow-gaging stations used in the low-flow regressions in Kentucky-Continued

$\left[\mathrm{mi}^{2}\right.$, square mile; $\mathrm{ft} / \mathrm{s}$, cubic foot per second; climate years, the 12-month period April 1--March 31 is identified by the year in which it ends; Regression: B, both the logistic regression and weighted-least-squares regression; KY, Kentucky; W, weighted-least-squares regression only; L, logistic regression only; period of record for the low-flow, partial-record stations indicates years in which low-flow measurements were made; --, not applicable]

\begin{tabular}{|c|c|c|c|c|c|c|c|}
\hline $\begin{array}{l}\text { Station } \\
\text { number }\end{array}$ & Regression & Station name & $\begin{array}{l}\text { Total } \\
\text { drainage } \\
\text { area } \\
\left(\mathrm{mi}^{2}\right)\end{array}$ & \multicolumn{2}{|c|}{$\begin{array}{c}\text { Streamflow- } \\
\text { variability index } \\
\left.\text { (log base-10 ft }{ }^{3} / \mathrm{s}\right)\end{array}$} & $\begin{array}{l}\text { Homogeneous } \\
\text { unregulated } \\
\text { period of record } \\
\text { (climate years) }\end{array}$ & $\begin{array}{c}\text { Number } \\
\text { of } \\
\text { years }\end{array}$ \\
\hline $03309100^{1}$ & W & $\begin{array}{l}\text { Wet Prong Buffalo Creek Nr Mammoth } \\
\text { Cave, }\end{array}$ & 2.74 & -- & 0.91 & $1963-75$ & 13 \\
\hline 03310000 & $\mathrm{~B}$ & $\begin{array}{l}\text { North Fork Nolin River at } \\
\text { Hodgenville, KY }\end{array}$ & 36.70 & 0.777 & 0.55 & $1943-73$ & 31 \\
\hline $03310078^{1}$ & W & $\begin{array}{l}\text { South Fork Nolin River at Mathers } \\
\text { Mill, KY }\end{array}$ & 50.10 & -- & 0.46 & $\begin{array}{l}1975-79,1981-82 \\
1989\end{array}$ & 8 \\
\hline 03310400 & $\mathrm{~B}$ & Bacon Creek near Priceville, KY & 80.60 & 0.376 & 0.45 & $1961-94$ & 34 \\
\hline $03311100^{1}$ & $\mathrm{~W}$ & Bylew Creek Near Mammoth Cave, Ky & 5.11 & -- & 1.15 & $1962-75$ & 14 \\
\hline 03311600 & $\mathrm{~B}$ & Beaverdam Creek at Rhoda, KY & 10.90 & 0.546 & 0.55 & 1974-94 & 21 \\
\hline 03312000 & $\mathrm{~B}$ & Bear Creek near Leitchfield, KY & 30.80 & 0.839 & 0.97 & $1951-71$ & 21 \\
\hline 03312500 & $\mathrm{~B}$ & Barren River near Pageville, KY & 532.00 & 0.487 & 0.55 & $1940-63$ & 24 \\
\hline 03312765 & $\mathrm{~B}$ & Beaver Creek at Hwy 31 East, KY & 47.10 & 0.51 & 0.55 & $1993-2002$ & 10 \\
\hline 03313000 & $\mathrm{~B}$ & Barren River near Finney, KY & 942.00 & 0.503 & 0.55 & $1943-50,1962-63$ & 10 \\
\hline 03313500 & $\mathrm{~B}$ & West Bays Fork at Scottsville, KY & 7.46 & 0.638 & 0.55 & $1952-67$ & 16 \\
\hline $03313700^{3}$ & B & $\begin{array}{l}\text { West Fork Drakes Creek near } \\
\text { Franklin, KY }\end{array}$ & 111.00 & 0.552 & 0.55 & $1970-79$ & 10 \\
\hline 03318200 & $\mathrm{~B}$ & Rock Lick Creek near Glen Dean, KY & 20.10 & 1.007 & 1.11 & $1958-71$ & 14 \\
\hline 03318800 & $\mathrm{~B}$ & Caney Creek near Horse Branch, KY & 117.00 & 1.314 & 1.15 & $1958-92$ & 35 \\
\hline 03319000 & $\mathrm{~B}$ & Rough River near Dundee, KY & 757.00 & 0.697 & 0.74 & $1941-59$ & 19 \\
\hline 03320500 & $\mathrm{~B}$ & Pond River near Apex, KY & 194.00 & 1.052 & 1.05 & $1942-2006$ & 65 \\
\hline 03321350 & $\mathrm{~B}$ & $\begin{array}{l}\text { South Fork Panther Creek near } \\
\text { Whitesville, KY }\end{array}$ & 58.20 & 1.091 & 1.15 & $1969-83$ & 15 \\
\hline 03322360 & $\mathrm{~L}$ & Beaverdam Creek near Corydon, KY & 10.70 & 1.329 & 1.15 & $\begin{array}{l}\text { 1974-82, } 1985-86 \\
\quad 1989-94\end{array}$ & 17 \\
\hline 03383000 & $\mathrm{~B}$ & Tradewater River at Olney, KY & 255.00 & 1.145 & 1.15 & $1942-75$ & 34 \\
\hline 03384000 & $\mathrm{~L}$ & Rose Creek at Nebo, KY & 2.10 & 1.154 & 1.15 & $1953-70$ & 18 \\
\hline 03400500 & $\mathrm{~B}$ & Poor Fork at Cumberland, KY & 82.10 & 0.523 & 0.55 & $1941-60$ & 20 \\
\hline $03400785^{1}$ & $\mathrm{~B}$ & Martins Fork above Smith, KY & 23.70 & 0.575 & 0.55 & $1986-91$ & 6 \\
\hline 03401000 & $\mathrm{~B}$ & Cumberland River near Harlan, KY & 373.00 & 0.536 & 0.55 & $1941-78$ & 38 \\
\hline
\end{tabular}




\begin{tabular}{|c|c|c|c|c|c|c|c|c|}
\hline \multicolumn{5}{|c|}{ Magnitude of low-flow frequency $\left(\mathrm{ft}^{3} / \mathrm{s}\right)$} & \multirow{2}{*}{\multicolumn{2}{|c|}{$\begin{array}{l}\text { Annual 7-day low } \\
\text { flow equal to zero }\end{array}$}} & \multirow{2}{*}{\multicolumn{2}{|c|}{$\begin{array}{l}\text { Annual 30-day low } \\
\text { flow equal to zero }\end{array}$}} \\
\hline \multirow{2}{*}{$\begin{array}{l}\text { 30-day, } \\
\text { 2-year }\end{array}$} & & \multirow{2}{*}{$\begin{array}{l}\text { 7-day, } \\
\text { 2-year }\end{array}$} & & \multirow{2}{*}{$\begin{array}{l}\text { 7-day, } \\
\text { 20-year }\end{array}$} & & & & \\
\hline & $\begin{array}{l}\text { 30-day, } \\
5 \text {-year }\end{array}$ & & $\begin{array}{l}\text { 7-day, } \\
10 \text {-year }\end{array}$ & & Number & Frequency & Number & Frequency \\
\hline 1.1 & 0.8 & 1 & 0.6 & 0.5 & -- & -- & -- & -- \\
\hline 0.28 & 0.15 & 0.17 & 0 & 0 & 2 & 0.12 & 1 & 0.06 \\
\hline 0.96 & 0.12 & 0.32 & 0 & 0 & 6 & 0.19 & 1 & 0.03 \\
\hline 6 & 3.9 & 5 & 2.7 & 2.3 & -- & -- & -- & -- \\
\hline 10.2 & 7.42 & 8.83 & 5.65 & 4.95 & 0 & 0.00 & 0 & 0.00 \\
\hline 76.6 & 58.9 & 67.6 & 44.2 & 38.4 & 0 & 0.00 & 0 & 0.00 \\
\hline 1.8 & 0.9 & 1.4 & 0.5 & 0.3 & -- & -- & -- & -- \\
\hline 85.4 & 64.7 & 72.2 & 51.1 & 46.4 & 0 & 0.00 & 0 & 0.00 \\
\hline 1.1 & 0.7 & 0.9 & 0.5 & 0.4 & -- & -- & -- & -- \\
\hline 0.92 & 0.59 & 0.71 & 0.27 & 0.2 & 0 & 0.00 & 0 & 0.00 \\
\hline 0.71 & 0.06 & 0.32 & 0 & 0 & 5 & 0.24 & 3 & 0.14 \\
\hline 72.3 & 50.1 & 54.4 & 30.7 & 26.4 & 0 & 0.00 & 0 & 0.00 \\
\hline 6.4 & 4.17 & 4.52 & 2.04 & 1.62 & 0 & 0.00 & 0 & 0.00 \\
\hline 105 & 86.3 & 79.7 & 58.1 & 54 & 0 & 0.00 & 0 & 0.00 \\
\hline 0.43 & 0.18 & 0.26 & 0.07 & 0 & 1 & 0.06 & 0 & 0.00 \\
\hline 12 & 10.4 & 8.5 & 6.58 & 6.31 & 0 & 0.00 & 0 & 0.00 \\
\hline 44.3 & 29.5 & 32.9 & 17 & 14.2 & 0 & 0.00 & 0 & 0.00 \\
\hline 143 & 97.7 & 105 & 61.1 & 54.6 & 0 & 0.00 & 0 & 0.00 \\
\hline 0.84 & 0.02 & 0.21 & 0 & 0 & 8 & 0.38 & 4 & 0.19 \\
\hline 18.2 & 13.1 & 14.3 & 9.6 & 8.96 & 0 & 0.00 & 0 & 0.00 \\
\hline 0.38 & 0.19 & 0.18 & 0 & 0 & 2 & 0.11 & 0 & 0.00 \\
\hline 0.21 & 0.05 & 0 & 0 & 0 & 8 & 0.57 & 1 & 0.07 \\
\hline 0.15 & 0 & 0 & 0 & 0 & 22 & 0.63 & 9 & 0.26 \\
\hline 28.1 & 18.8 & 19.1 & 13.2 & 12.6 & 0 & 0.00 & 0 & 0.00 \\
\hline 0.75 & 0.05 & 0.16 & 0 & 0 & 25 & 0.38 & 7 & 0.11 \\
\hline 0.74 & 0.04 & 0 & 0 & 0 & 7 & 0.47 & 1 & 0.07 \\
\hline 0 & 0 & 0 & 0 & 0 & 15 & 0.88 & 9 & 0.53 \\
\hline 0.76 & 0.05 & 0.17 & 0 & 0 & 12 & 0.35 & 4 & 0.12 \\
\hline 0 & 0 & 0 & 0 & 0 & 18 & 1.00 & 18 & 1.00 \\
\hline 10.7 & 6.53 & 8.27 & 3.6 & 2.77 & 0 & 0.00 & 0 & 0.00 \\
\hline 2.9 & 1.3 & 1.9 & 0.5 & 0.4 & 0 & 0.00 & 0 & 0.00 \\
\hline 45.9 & 24.2 & 28.5 & 11.2 & 8.62 & 0 & 0.00 & 0 & 0.00 \\
\hline
\end{tabular}


Table 2. Low-flow frequencies for streamflow-gaging stations used in the low-flow regressions in Kentucky-Continued

$\left[\mathrm{mi}^{2}\right.$, square mile; $\mathrm{ft} / \mathrm{s}$, cubic foot per second; climate years, the 12-month period April 1--March 31 is identified by the year in which it ends; Regression: B, both the logistic regression and weighted-least-squares regression; KY, Kentucky; W, weighted-least-squares regression only; L, logistic regression only; period of record for the low-flow, partial-record stations indicates years in which low-flow measurements were made; --, not applicable]

\begin{tabular}{|c|c|c|c|c|c|c|c|}
\hline \multirow{2}{*}{$\begin{array}{l}\text { Station } \\
\text { number }\end{array}$} & \multirow{2}{*}{ Regression } & \multirow{2}{*}{ Station name } & \multirow{2}{*}{$\begin{array}{c}\text { Total } \\
\text { drainage } \\
\text { area } \\
\left(\mathrm{mi}^{2}\right)\end{array}$} & \multicolumn{2}{|c|}{$\begin{array}{c}\text { Streamflow- } \\
\text { variability index } \\
\left(\log \text { base-10 } \mathrm{ft}^{3} / \mathrm{s}\right)\end{array}$} & \multirow{2}{*}{$\begin{array}{l}\text { Homogeneous } \\
\text { unregulated } \\
\text { period of record } \\
\text { (climate years) }\end{array}$} & \multirow{2}{*}{$\begin{array}{c}\text { Number } \\
\text { of } \\
\text { years }\end{array}$} \\
\hline & & & & $\begin{array}{l}\text { Station } \\
\text { value }\end{array}$ & $\begin{array}{l}\text { Map } \\
\text { value }\end{array}$ & & \\
\hline $03402930^{1}$ & $\mathrm{~W}$ & Fourmile Creek At Fourmile, Ky & 6.20 & -- & 0.6 & $\begin{array}{l}1988-89,1991-92 \\
2006\end{array}$ & 5 \\
\hline $03403000^{4}$ & $\mathrm{~B}$ & Cumberland River near Pineville, KY & 809.00 & 0.588 & 0.56 & $1940-71$ & 32 \\
\hline 03403500 & $\mathrm{~B}$ & Cumberland River at Barbourville, KY & 960.00 & 0.613 & 0.57 & $1924-31,1949-71$ & 31 \\
\hline 03403910 & $\mathrm{~B}$ & Clear Fork at Saxton, KY & 331.00 & 0.539 & 0.55 & $\begin{array}{l}1970-90,1997- \\
2004\end{array}$ & 29 \\
\hline 03404000 & $\mathrm{~B}$ & Cumberland River at Williamsburg, KY & $1,607.00$ & 0.599 & 0.57 & $1952-78$ & 27 \\
\hline 03404500 & $\mathrm{~B}$ & $\begin{array}{l}\text { Cumberland River at Cumberland } \\
\text { Falls, KY }\end{array}$ & $1,976.00$ & 0.65 & 0.58 & $\begin{array}{l}\text { 1909-11, 1916-31, } \\
1934-60\end{array}$ & 46 \\
\hline 03404900 & $\mathrm{~B}$ & Lynn Camp Creek at Corbin, KY & 53.00 & 0.625 & 0.6 & 1975-89 & 15 \\
\hline 03406000 & $\mathrm{~B}$ & Wood Creek near London, KY & 3.90 & 0.526 & 0.7 & $1955-71$ & 17 \\
\hline 03406500 & $\mathrm{~B}$ & Rockcastle River at Billows, KY & 604.00 & 0.693 & 0.7 & $1938-90$ & 53 \\
\hline 03407100 & $\mathrm{~B}$ & Cane Branch near Parkers Lake, KY & 0.65 & 0.579 & 0.7 & $1957-66$ & 10 \\
\hline 03407300 & $\mathrm{~B}$ & Helton Branch at Greenwood, KY & 0.85 & 0.454 & 0.6 & $1957-74$ & 18 \\
\hline 03407500 & $\mathrm{~B}$ & Buck Creek near Shopville, KY & 165.00 & 1.054 & 1.04 & $1954-70$ & 17 \\
\hline 03410500 & $\mathrm{~B}$ & $\begin{array}{l}\text { South Fork Cumberland River near } \\
\text { Stearns, KY }\end{array}$ & 954.00 & 0.595 & 0.6 & $1944-2005$ & 62 \\
\hline 03411000 & $\mathrm{~B}$ & $\begin{array}{l}\text { South Fork Cumberland River at } \\
\text { Nevelsville, KY }\end{array}$ & $1,267.00$ & 0.611 & 0.6 & $1916-31,1934-50$ & 33 \\
\hline 03412500 & $\mathrm{~B}$ & Pitman Creek at Somerset, KY & 31.00 & 0.754 & 0.71 & $1955-72$ & 18 \\
\hline 03413200 & $\mathrm{~B}$ & Beaver Creek near Monticello, KY & 43.20 & 0.605 & 0.6 & $1970-83,1991-95$ & 19 \\
\hline 03435140 & $\mathrm{~B}$ & Whippoorwill Creek near Claymour, KY & 20.70 & 1.046 & 1.05 & $1975-91$ & 17 \\
\hline 03437500 & $\mathrm{~B}$ & $\begin{array}{l}\text { South Fork Little River at Hopkinsville, } \\
\text { KY }\end{array}$ & 46.10 & 0.775 & 0.82 & $1951-60$ & 10 \\
\hline 03438000 & $\mathrm{~B}$ & Little River near Cadiz, KY & 244.00 & 0.57 & 0.72 & $1941-62$ & 22 \\
\hline 03438070 & $\mathrm{~B}$ & $\begin{array}{l}\text { Muddy Fork Little River near } \\
\text { Cerulean, KY }\end{array}$ & 30.30 & 1.159 & 1.15 & $1970-83$ & 14 \\
\hline 03610545 & $\mathrm{~B}$ & $\begin{array}{l}\text { West Fork Clarks River near } \\
\text { Brewers, KY }\end{array}$ & 68.30 & 0.518 & 0.55 & $1970-83,1990-94$ & 19 \\
\hline 03611260 & $\mathrm{~B}$ & Massac Creek near Paducah, KY & 10.40 & 0.681 & 0.65 & 1973-93 & 21 \\
\hline 03611800 & $\mathrm{~B}$ & Bayou Creek near Heath, KY & 6.55 & 0.609 & 0.65 & $1995-2006$ & 12 \\
\hline 07022500 & $\mathrm{~L}$ & Perry Creek near Mayfield, KY & 1.72 & 1.053 & 1.35 & $1954-66,1969-72$ & 17 \\
\hline 07023500 & $\mathrm{~L}$ & Obion Creek at Pryorsburg, KY & 37.00 & 1.457 & 1.34 & $1953-73$ & 21 \\
\hline $07025440^{1}$ & $\mathrm{~W}$ & Harris Fork Creek Near Fulton, KY & 3.99 & -- & 0.55 & $1988,1992,2006$ & 3 \\
\hline
\end{tabular}

\footnotetext{
${ }^{1}$ Low-flow, partial-record streamflow-gaging stations; or a long-term-continuous-record, streamflow-gaging station having less than 10 years record, which was treated as a low-flow, partial-reacord station..

${ }^{2}$ Combined records for stations 03237250 and 03237255.

${ }^{3}$ Station 03313700 had estimated 3 cubic feet per second withdrawal for water supply for the period 1977-79, which was added to the measured low flows prior to the frequency analysis.

${ }^{4}$ Combined records for stations 03402900 and 03403000 .

${ }^{5}$ Refers to the number and frequency of occurrence of annual D-day low flows equalling zero.
} 


\begin{tabular}{|c|c|c|c|c|c|c|c|c|}
\hline \multicolumn{5}{|c|}{ Magnitude of low-flow frequency $\left(\mathrm{ft}^{3} / \mathrm{s}\right)$} & \multirow{2}{*}{\multicolumn{2}{|c|}{$\begin{array}{l}\text { Annual 7-day low } \\
\text { flow equal to zero }\end{array}$}} & \multirow{2}{*}{\multicolumn{2}{|c|}{$\begin{array}{l}\text { Annual 30-day low } \\
\text { flow equal to zero }\end{array}$}} \\
\hline \multirow{2}{*}{$\begin{array}{l}\text { 30-day, } \\
\text { 2-year }\end{array}$} & \multirow{2}{*}{$\begin{array}{l}\text { 30-day, } \\
\text { 5-year }\end{array}$} & \multirow{2}{*}{$\begin{array}{l}\text { 7-day, } \\
\text { 2-year }\end{array}$} & & & & & & \\
\hline & & & $\begin{array}{l}\text { 7-day, } \\
\text { 10-year }\end{array}$ & $\begin{array}{l}\text { 7-day, } \\
\text { 20-year }\end{array}$ & Number & Frequency & Number & Frequency \\
\hline 0.4 & 0.1 & 0.1 & 0.028 & 0.019 & -- & -- & -- & -- \\
\hline 63.3 & 32 & 39.9 & 12.8 & 9.01 & 0 & 0.00 & 0 & 0.00 \\
\hline 73.3 & 32.6 & 44.2 & 12 & 7.82 & 0 & 0.00 & 0 & 0.00 \\
\hline 36.2 & 18.6 & 21.8 & 8.26 & 6.35 & 0 & 0.00 & 0 & 0.00 \\
\hline 145 & 64.4 & 80.6 & 20.6 & 12.9 & 0 & 0.00 & 0 & 0.00 \\
\hline 99 & 42.9 & 56.4 & 16.4 & 11.4 & 0 & 0.00 & 0 & 0.00 \\
\hline 2.72 & 1.47 & 1.41 & 0.18 & 0.08 & 0 & 0.00 & 0 & 0.00 \\
\hline 0.47 & 0.35 & 0.37 & 0.27 & 0.25 & 0 & 0.00 & 0 & 0.00 \\
\hline 19.8 & 9.05 & 12.2 & 3.47 & 2.39 & 0 & 0.00 & 0 & 0.00 \\
\hline 0.06 & 0.04 & 0.03 & 0.01 & 0.01 & 0 & 0.00 & 0 & 0.00 \\
\hline 0.15 & 0.12 & 0.12 & 0.09 & 0.08 & 0 & 0.00 & 0 & 0.00 \\
\hline 0.4 & 0.02 & 0.04 & 0 & 0 & 8 & 0.47 & 2 & 0.12 \\
\hline 78.2 & 43.9 & 49.9 & 22.2 & 17.9 & 0 & 0.00 & 0 & 0.00 \\
\hline 82.8 & 45.8 & 55.8 & 23.6 & 18.4 & 0 & 0.00 & 0 & 0.00 \\
\hline 0.72 & 0.33 & 0.3 & 0.05 & 0 & 1 & 0.06 & 0 & 0.00 \\
\hline 2.9 & 1.97 & 2.21 & 1.34 & 1.17 & 0 & 0.00 & 0 & 0.00 \\
\hline 0.4 & 0 & 0.02 & 0 & 0 & 8 & 0.47 & 5 & 0.29 \\
\hline 1.28 & 0.63 & 0.91 & 0.32 & 0.25 & 0 & 0.00 & 0 & 0.00 \\
\hline 21.1 & 14.6 & 18.1 & 9.64 & 8.24 & 0 & 0.00 & 0 & 0.00 \\
\hline 0.18 & 0.01 & 0.01 & 0 & 0 & 6 & 0.43 & 1 & 0.07 \\
\hline 6.52 & 4.5 & 3.96 & 2.11 & 1.77 & 0 & 0.00 & 0 & 0.00 \\
\hline 0.42 & 0.3 & 0.28 & 0.14 & 0.12 & 0 & 0.00 & 0 & 0.00 \\
\hline 0.2 & 0.15 & 0.1 & 0.04 & 0.03 & 0 & 0.00 & 0 & 0.00 \\
\hline 0 & 0 & 0 & 0 & 0 & 17 & 1.00 & 15 & 0.88 \\
\hline 0 & 0 & 0 & 0 & 0 & 18 & 0.86 & 9 & 0.43 \\
\hline 0.2 & 0.1 & 0.1 & 0.1 & 0.047 & -- & -- & -- & -- \\
\hline
\end{tabular}


Table 3. Basin characteristics tested for use in the low-flow regression analyses in Kentucky.

[ft, foot; DEM, digital elevation model; $\mathrm{ft}$ /s, cubic foot per second; Ksat, permeability of saturated soil; NAD 83, North American Datum of 1983; NAVD 88, North American Vertical Datum of 1988; KGS, Kentucky Geological Survey; SAS, Statistical Analysis System, Inc. (a registered trademark of SAS Institute, Inc., Cary, N.C.); PRISM, Parameter-elevation Regressions on Independent Slopes Model; $\mu \mathrm{m} / \mathrm{s}$, micrometer per second; SSURGO, Soil Survey Geographic (Database); USDA, U.S. Department of Agriculture; ArcGIS and ArcHydro Tools are trademarks of Environmental Systems Research Institute, Inc., Redlands, Calif.]

\begin{tabular}{|c|c|c|c|}
\hline Name & Units & Method & Source data \\
\hline \multicolumn{4}{|c|}{ Physical measurements } \\
\hline Total drainage area & Square miles & ArcHydro flow accumulation & $\begin{array}{l}\text { Statewide Kentucky Single Zone } \\
\text { 30-ft DEM (http://technology.ky.gov/gis/) condi- } \\
\text { tioned to conform to the National Hydrography } \\
\text { Dataset, } 1: 24,000 \text { scale (http://nhd/usgs/gov). }\end{array}$ \\
\hline
\end{tabular}

Centroid latitude

Centroid longitude

Gage latitude

Gage longitude

Mean basin elevation

Stream slope, 10/85 method
Feet per mile

ArcGIS 9.0 centroid method

ArcGIS 9.0 centroid method

ArcGIS 9.0

ArcGIS 9.0

NAVD 88 and ArcGIS 9.0

Feet above mean sea level

ArcHydro method
NAD 83

NAD 83

NAD 83

NAD 83

National Elevation Dataset elevation grid, 10- and 30-meter resolution (http://nhd.usgs.gov)

National Hydrography Dataset, 1:24,000 scale (http://nhd.usgs.gov) and National Elevation Dataset elevation grid, 10- and 30-meter resolution (http://nhd.usgs.gov)

\begin{tabular}{|c|c|c|}
\hline & & Land cover \\
\hline Cultivated crops & Percent & $\begin{array}{l}\text { (Area A82/drainage area) times } \\
100, \text { where classes are defined } \\
\text { at } h t t p: / / w w w . m r l c . g o v\end{array}$ \\
\hline Forest & Percent & $\begin{array}{l}\text { (Sum of areas A42-A43/drainage } \\
\text { area) times } 100, \text { where classes } \\
\text { are defined at http://www.mrlc. } \\
\text { gov }\end{array}$ \\
\hline Wetlands & Percent & $\begin{array}{l}\text { (Sum of areas A11, A90 and } \\
\text { A95/drainage area) times } 100, \\
\text { where classes are defined at } \\
\text { http://www.mrlc.gov }\end{array}$ \\
\hline Grasslands & Percent & $\begin{array}{l}\text { (Sum of area A71/drainage area) } \\
\text { times } 100, \text { where classes are } \\
\text { defined at http://www.mrlc.gov }\end{array}$ \\
\hline Pasture/hay & Percent & $\begin{array}{l}\text { (Sum of area A81/drainage area) } \\
\text { times } 100, \text { where classes are } \\
\text { defined at } h t t p: / / w w w . m r l c . g o v\end{array}$ \\
\hline
\end{tabular}

U.S. Geological Survey, 2007-National LandCover Database, 2001 (http://www.mrlc.gov)

U.S. Geological Survey, 2007-National LandCover Database, 2001 (http://www.mrlc.gov)

U.S. Geological Survey, 2007-National LandCover Database, 2001 (http://www.mrlc.gov)

U.S. Geological Survey, 2007-National LandCover Database, 2001 (http://www.mrlc.gov)

U.S. Geological Survey, 2007-National LandCover Database, 2001 (http://www.mrlc.gov) 
Table 3. Basin characteristics tested for use in the low-flow regression analyses in Kentucky-C Continued

[ft, foot; DEM, digital elevation model; $\mathrm{ft}^{3} / \mathrm{s}$, cubic foot per second; Ksat, permeability of saturated soil; NAD 83, North American Datum of 1983; NAVD 88, North American Vertical Datum of 1988; KGS, Kentucky Geological Survey; SAS, Statistical Analysis System, Inc. (a registered trademark of SAS Institute, Inc., Cary, N.C.); PRISM, Parameter-elevation Regressions on Independent Slopes Model; $\mu \mathrm{m} / \mathrm{s}$, micrometer per second; SSURGO, Soil Survey Geographic (Database); USDA, U.S. Department of Agriculture; ArcGIS and ArcHydro Tools are trademarks of Environmental Systems Research Institute, Inc., Redlands, Calif.]

\begin{tabular}{lccc}
\hline \multicolumn{1}{c}{ Name } & Units & Method & Sourc \\
& & Geology & \\
\hline Mississippian & Percent and & (Selected cells/basin cells) & Geology of Kentucky, sin \\
& indicator & times 100 & 2002 (http://kgsweb.uk \\
& & & kygeol.ZIP)
\end{tabular}

Physiography

Physiographic regions includ- Percent and (Selcted cells/basin cells) ing Eastern Coalfield, Eastern Pennyroyal, Inner Bluegrass, Outer Bluegrass, Western Pennyroyal, Western Coalfield, Purchase

\section{indicator} times 100
H.L. Nelson Jr., U.S. Geological Survey, written commun., 2005; adapted from Physiographic Diagram of Kentucky (Kentucky Geological Survey, 1980)

\section{Hydrography}

Streamflow-varibility index
$\quad$ (map value)
Streamflow-varibility index $\mathrm{ft}^{3} / \mathrm{s}$
$\quad$ (station value)

Flow-duration ratio (map value)

Flow-duration ratio (station value)

Recession index (station value)

Unitless

Unitless

Recession index (station value)
Area-weighted average
Days to decline one log cycle

SAS percentiles on continuous ranking of the daily mean streamflow values

Area-weighted average

Ratio of the 20- and 90-percent flow-duration flows determined on SAS percentiles on continuous ranking of the daily mean streamflow values

Graphical (Riggs, 1964)
Plate 2

U.S. Geological Survey National Water Information System (NWIS)

Map of flow-duration ratio

U.S. Geological Survey National Water Information System (NWIS)

U.S. Geological Survey National Water Information System (NWIS) 
Table 3. Basin characteristics tested for use in the low-flow regression analyses in Kentucky.-Continued

[ft, foot; DEM, digital elevation model; fts/s, cubic foot per second; Ksat, permeability of saturated soil; NAD 83, North American Datum of 1983; NAVD 88, North American Vertical Datum of 1988; KGS, Kentucky Geological Survey; SAS, Statistical Analysis System, Inc. (a registered trademark of SAS Institute, Inc., Cary, N.C.); PRISM, Parameter-elevation Regressions on Independent Slopes Model; $\mu \mathrm{m} / \mathrm{s}$, micrometer per second; SSURGO, Soil Survey Geographic (Database); USDA, U.S. Department of Agriculture; ArcGIS and ArcHydro Tools are trademarks of Environmental Systems Research Institute, Inc., Redlands, Calif.]

\begin{tabular}{|c|c|c|c|}
\hline Name & Units & Method & Source data \\
\hline \multicolumn{4}{|c|}{ Meteorological } \\
\hline $\begin{array}{l}\text { Precipitation (mean monthly, } \\
\text { seasonal, and annual) }\end{array}$ & $\begin{array}{l}\text { Millimeters } \\
\text { times } 100\end{array}$ & $\begin{array}{l}\text { ArcGIS areal mean, } \\
\text { centroid, and gage values }\end{array}$ & $\begin{array}{l}\text { PRISM Group at Oregon State University monthly } \\
\text { and annual values 1971-2000 (http: }|| O R I O N|F \$| \\
\text { Metadatalmeta_30seclus_ppt01_30) }\end{array}$ \\
\hline $\begin{array}{l}\text { Precipitation frequency } \\
\quad \text { (24-hour, 2-year) }\end{array}$ & $\begin{array}{l}\text { Inches times } \\
1,000\end{array}$ & ArcGIS areal mean & $\begin{array}{l}\text { National Oceanic and Atmospheric Administration } \\
\text { Atlas 14, Volume } 2 \text { (http://www.nws.noaa.gov/ } \\
\text { ohd/hdsc/index.html) }\end{array}$ \\
\hline $\begin{array}{l}\text { Climate region (Eastern, } \\
\text { Bluegrass, Central, Western } \\
\text { Kentucky) }\end{array}$ & $\begin{array}{l}\text { Percent and } \\
\text { indicator }\end{array}$ & $\begin{array}{l}\text { (Selected cells/basin cells) } \\
\text { times } 100\end{array}$ & $\begin{array}{l}\text { Climate Regions of Kentucky (Kentucky Climate } \\
\text { Center at Western Kentucky University, 2008a, b) }\end{array}$ \\
\hline
\end{tabular}

\section{Soils}

Water Holding Capacity Unitless

Conductivity Multiplier

Unitless

Soil Depth Inches

Field Capacity

Unitless

Permeability

Inches per hour and indicator

Porosity

Unitless

Sand, silt, clay

Percent
Averaged for depth where Ksat $>1 \mu \mathrm{m} / \mathrm{s}$ as reported in SSURGO then representative values rasterized and sampled by drainage basin.

Averaged for depth where Ksat $>1 \mu \mathrm{m} / \mathrm{s}$ as reported in SSURGO then representative values rasterized and sampled by drainage basin.

Averaged for depth where Ksat $>1 \mu \mathrm{m} / \mathrm{s}$ as reported in SSURGO then representative values rasterized and sampled by drainage basin.

Averaged for depth where Ksat $>1 \mu \mathrm{m} / \mathrm{s}$ as reported in SSURGO then representative values rasterized and sampled by drainage basin.

Averaged for depth where Ksat $>1 \mu \mathrm{m} / \mathrm{s}$ as reported in SSURGO then representative values rasterized and sampled by drainage basin.

Averaged for depth where Ksat $>1 \mu \mathrm{m} / \mathrm{sec}$ as reported in SSURGO then representative values rasterized and sampled by drainage basin.

Averaged for depth where Ksat $>1 \mu \mathrm{m} / \mathrm{sec}$ as reported in SSURGO then representative values rasterized and sampled by drainage basin.
Soil Survey Geographic (SSURGO) Data for Kentucky (http://www.soils.usda.gov/survey/ geography/ssurgo/), USDA-Natural Resources Conservation Service (2007)

Soil Survey Geographic (SSURGO) Data for Kentucky (http://www.soils.usda.gov/survey/ geography/ssurgo/), USDA-Natural Resources Conservation Service (2007)

Soil Survey Geographic (SSURGO) Data for Kentucky (http://www.soils.usda.gov/survey/ geography/ssurgo/), USDA-Natural Resources Conservation Service (2007)

Soil Survey Geographic (SSURGO) Data for Kentucky (http://www.soils.usda.gov/survey/ geography/ssurgo/), USDA-Natural Resources Conservation Service (2007)

Soil Survey Geographic (SSURGO) Data for Kentucky (http://www.soils.usda.gov/survey/ geography/ssurgo/), USDA-Natural Resources Conservation Service (2007)

Soil Survey Geographic (SSURGO) Data for Kentucky (http://www.soils.usda.gov/survey/ geography/ssurgo/), USDA-Natural Resources Conservation Service (2007)

Soil Survey Geographic (SSURGO) Data for Kentucky (http://www.soils.usda.gov/survey/ geography/ssurgo/), USDA-Natural Resources Conservation Service (2007) 


\section{Glossary}

climate year The 12-month period from A pril 1 through $M$ arch 31. The climate year is designated by the calendar year in which the period ends.

coefficient of multiple determination The proportion of the variation in the dependent variable explained by the variables in a fitted regression model. Reported values are adjusted for error degrees of freedom.

level of significance The selected maximum probability of making a Type I error, or rejecting a true null hypothesis. $H$ ypothesis tests were used to determine if statistically significant relations existed between dependent and explanatory variables of regression models.

local diversion A localized transfer of water, such as a water-supply withdrawal or wastewater releases, that artificially increase or decrease streamflow in a reach.

multicollinearity A high correlation (near linear dependencies) between two or more explanatory variables of a regression. M ulticollinearity causes instability in the estimates of the least-squares regression coefficients.

multiple-linear regression $A$ method used to model the linear relation between a dependent variable and one or more independent variables.

ordinary-least-squares regression A method of fitting a regression model in which the sum of squared residuals (see Residual) is minimized.

prediction sum of squares (press) statistic A measure of model-prediction error useful in regression-model selection. PRESS is computed by summing the square of the prediction residuals resulting from the series of predictions of each observation by regressions defined by using all other observations. Thus, each observation is left out of the regression data set and is not used in prediction of that observation. This process simulates prediction with new data and is a form of data splitting useful for model validation (A llen, 1971, 1974; and M ontgomery and Peck, 1982).

regulated streamflow Streamflow controlled by upstream hydraulic structures such as dams.

residual The difference between value of the streamflow statistic computed by use of streamflow-gaging data and value estimated by use of a regression model. standard error of estimate A measure of model-fitting error; it is the standard deviation of the residuals of a regression adjusted for error degrees of freedom. Percentage values in this report were estimated by use of model root-mean-square error, or the square root of the sum of the squares of the residuals divided by the error degrees of freedom $-n-k-1$, where $n$ is the number of observations and $k$ is the number of explanatory variables in the regression - (SA S Institute, Inc., 1985) and information from Hardison (1971).

standard error of prediction A measure of model-prediction error; it was estimated as the square root of the PRESS divided by the degrees of freedom for error (SA S Institute, Inc., 1985; M ontgomery and Peck, 1982; and Choquette, 1988). (See Prediction Sum of Squares (PRESS) Statistic.)

streamflow Discharge, measured as the volume of water that passes a given point in a given period of time (cubic feet per second), that flows in a channel whether or not it is affected by diversion or regulation.

streamflow-gaging station An installation that provides systematic observations of stage from which streamflow is computed.

variance inflation factor (vif) An indicator of multicollinearity; it is a measure of the combined effect of the dependencies among explanatory variables on the variance of each term in a regression model ( $M$ arquardt, 1970; and M ontgomery and Peck, 1982).

water year The 12-month period from 0 ctober 1 through September 30 . The water year is designated by the cal endar year in which the period ends.

Note: In the standardized USGS regional-regression nomenclature the statistics and basin characteristics used herein are designated as follows: $30 Q_{2}, \mathrm{M} 30 \mathrm{D} 2 \mathrm{Y} ; 30 \mathrm{Q}_{5}, \mathrm{M} 30 \mathrm{D} 5 \mathrm{Y}$; 7Q, M 7D 2Y; 7Q $10^{\prime}$ M 7D 10Y; 7Q $20^{\prime}$ M 7D20Y; A, A BEL 8K; $V$, STREAM_VAR, respectively. 



\section{Appendix 1. Trend Tests of Long-Term Climate Data for Kentucky During 1895-2004}

Daily average temperature and total precipitation data for the 110-year period January 1895-December 2004 (Kentucky Climate Center at Western Kentucky University, 2008a, b), aggregated to monthly and annual values, were examined to assess how seasonal weather and long-term climate patterns (the climate signal) may have affected low-flow characteristics in Kentucky. Trend tests including the seasonal-Kendall (Mathsoft, Inc., 1999a, 1999b; Hirsch and others, 1982), Mann-Kendall (Helsel and Hirsch, 2002), and a modified generalized-least-squares regression on time were made by using the monthly, seasonal, and annual statewide temperature and precipitation data for Kentucky. The generalized-least-squares (GLS) regression against time compensates for possible serial correlation in the residuals of the regression. Serial correlation in time series may bias the results of the Mann-Kendall trend test (Dave Lorenz, U.S. Geological Survey, oral commun., 2007). The GLS regression against time was done by use of the AUTOREG procedure (Freund and Littell, 2000) in SAS 9 (SAS Institute, Inc., 2004).

Results of trend tests of annual and seasonal average temperatures and total precipitation for selected periods during 1895-2004 are shown in table 1-1. A p-value of 0.2 or less was indicative of possible trend. The results were, in general, consistent with the patterns observed in the LOWESS curves (fig. 4 in main report). No full-year trend in temperature during the entire 1895-2004 period was detected. A positive trend was detected in the statewide monthly cold-season (November-March) temperatures and negative trend in warm-season (April-October) temperatures from 1895-2004. Only one of the tests (seasonal-Kendall of monthly data) indicated a positive trend ( $\mathrm{p}$-value 0.0835 ) for full-year precipitation for the period 1895-2004.
Table 1-1. Summary of trends and trend-test p-values in statewide monthly and annual temperature and precipitation data for 1895-2004 in Kentucky.

$[\mathrm{T}$, temperature; P, precipitation; Winter, period including November through March; Summer; period including April through October; --, no trend detected at p-value 0.20 under null hypothesis of no trend; na, not tested; $\uparrow$, positive trend; $\downarrow$, negative trend

\begin{tabular}{|c|c|c|c|c|c|c|}
\hline \multirow{3}{*}{ Period } & \multirow{2}{*}{\multicolumn{2}{|c|}{ Full year }} & \multirow{2}{*}{\multicolumn{2}{|c|}{$\begin{array}{c}\text { Winter } \\
5 \text { months }\end{array}$}} & \multirow{2}{*}{\multicolumn{2}{|c|}{$\begin{array}{l}\text { Summer } \\
7 \text { months }\end{array}$}} \\
\hline & & & & & & \\
\hline & $\mathbf{T}$ & $\mathbf{P}$ & $\mathbf{T}$ & $\mathbf{P}$ & $\mathbf{T}$ & $\mathbf{P}$ \\
\hline \multicolumn{7}{|c|}{ Summary of trends detected at a p-value of 0.20} \\
\hline 1895-2004 & -- & $\uparrow \uparrow$ & $\bar{\uparrow}$ & -- & $\downarrow$ & $\bar{\uparrow}$ \\
\hline 1895-1945 & $\uparrow$ & na & $\uparrow$ & na & -- & na \\
\hline 1946-1975 & $\downarrow$ & na & -- & na & $\downarrow$ & na \\
\hline 1976-2004 & $\uparrow$ & na & $\uparrow$ & na & -- & na \\
\hline 1950-2004 & na & $\uparrow$ & $\uparrow$ & -- & -- & $\uparrow$ \\
\hline 1920-1950 & na & -- & na & -- & na & -- \\
\hline \multicolumn{7}{|c|}{ Seasonal-Kendall test $p$-values using monthly values } \\
\hline 1895-2004 & 0.4355 & 0.0835 & 0.1007 & 0.3265 & 0.0146 & 0.0052 \\
\hline $1895-1945$ & .2613 & na & .1982 & na & .7293 & na \\
\hline $1946-1975$ & .0693 & na & .4663 & na & .0777 & na \\
\hline 1976-2004 & .0287 & na & .0191 & na & .2212 & na \\
\hline 1950-2004 & na & .1893 & .0515 & .9304 & .8953 & .0624 \\
\hline $1920-1950$ & na & .9634 & na & .6319 & na & .6872 \\
\hline \multicolumn{7}{|c|}{ Kendall's tau test $p$-values using annual values } \\
\hline 1895-2004 & 0.7723 & 0.3187 & 0.1409 & 0.4695 & 0.0279 & 0.0035 \\
\hline 1895-1945 & .0911 & na & .0484 & na & .8012 & na \\
\hline 1946-1975 & .1387 & na & .3177 & na & .1042 & na \\
\hline $1976-2004$ & .0069 & na & .021 & na & .2448 & na \\
\hline 1950-2004 & na & .1723 & na & .5911 & na & .0183 \\
\hline $1920-1950$ & na & .7211 & na & .5074 & na & .7726 \\
\hline \multicolumn{7}{|c|}{$\begin{array}{l}\text { Generalized-least-squares regression-on-time test } \\
\text { p-values using annual values }\end{array}$} \\
\hline $1895-2004$ & 0.8733 & 0.2106 & 0.1187 & 0.4433 & 0.0261 & 0.0042 \\
\hline $1895-1945$ & .0926 & na & .0317 & na & .6788 & na \\
\hline 1946-1975 & .0863 & na & .3002 & na & .0914 & na \\
\hline 1976-2004 & .0039 & na & .0285 & na & .2153 & na \\
\hline 1950-2004 & na & .2874 & na & .596 & na & .0433 \\
\hline $1920-1950$ & na & .9525 & na & .4433 & na & .9972 \\
\hline
\end{tabular}





\section{Appendix 2. Trend-Test Screening of Annual 7-Day Low Flows for Selected Long-Term Continuous-Record Streamflow-Gaging Stations in Kentucky for Various Periods of Record}

\author{
The annual 7-day low-flow time series were screened \\ by use of trend-indicator tests to examine various periods \\ of record for each LTCR streamflow-gaging station in Ken- \\ tucky. Trends were examined by use of the Mann-Kendall test \\ (Helsel and Hirsch, 2002) (table 2-1), which may indicate \\ monotonic increasing and decreasing values over time. How- \\ ever, there must be no serial correlation of the observations \\ for the p-values from the Mann-Kendall test to be correct. \\ Annual low-flow time series may exhibit appreciable serial \\ correlation. Trends also were examined by use of the modified \\ generalized-least-squares regression approach, a regression
}

against time that compensates for possible serial correlation in the residuals of the regression. The data were examined after log base-10 transformation. The significance of the slope term in the regression of annual 7-day low flows versus time (year) by using a p-value of 0.2 was an indicator of possible trend. The Durbin-Watson statistic on the residuals from the regressions provided an indication of serial correlation. Most of the time, the results were consistent for these two trend tests. The raw computations for these two trend tests on the annual 7-day low flows for selected LTCR stations in Kentucky for various periods of the record are listed in table 2-1. 
Table 2-1. Trend-test screening of annual 7-day low flows for selected long-term continuous-record streamflow-gaging stations in Kentucky for various periods of record:

[p-value, probability statistically significant if less than $0.20 ; \mathrm{n}$, number of data values; $\mathrm{R}^{2}$, coefficient of determination; $<$ less than]

\begin{tabular}{|c|c|c|c|c|c|c|c|c|}
\hline \multirow{2}{*}{$\begin{array}{l}\text { Station } \\
\text { number }\end{array}$} & \multicolumn{2}{|c|}{ Trend analysis } & \multicolumn{6}{|c|}{ Regression analysis } \\
\hline & $\begin{array}{c}\text { Mann-Kendall } \\
\text { value }\end{array}$ & p-value & $\mathbf{R}^{2}$ & $\begin{array}{c}\text { Durbin-Watson } \\
\text { value }\end{array}$ & Slope & Slope p-value & Period of record & n \\
\hline 3207965 & 0.389 & 0.0143 & 0.5576 & 2.3971 & 0.0319 & 0.0001 & $1975-2006$ & 21 \\
\hline 3207965 & 0.022 & 0.9287 & 0.0486 & 2.5621 & 0.0148 & 0.5405 & 1975-1992 & 10 \\
\hline 3207965 & -0.315 & 0.1830 & 0.0468 & 3.0610 & -0.0120 & 0.5230 & $1993-2006$ & 11 \\
\hline 3208000 & 0.470 & $<.0001$ & 0.3769 & 1.9566 & 0.0258 & $<.0001$ & 1939-1992 & 54 \\
\hline 3208000 & 0.237 & 0.0661 & 0.1238 & 2.2665 & 0.0221 & 0.0565 & $1939-1968$ & 30 \\
\hline 3208000 & -0.036 & 0.8121 & 0.0219 & 0.9593 & 0.0062 & 0.5005 & 1970-1992 & 23 \\
\hline 3209300 & -0.033 & 0.8153 & 0.0652 & 1.0081 & 0.0061 & 0.2180 & 1968-1992 & 25 \\
\hline 3209500 & 0.590 & $<.0001$ & 0.5733 & 1.6888 & 0.0211 & $<.0001$ & 1939-2006 & 68 \\
\hline 3209500 & 0.033 & 0.8153 & 0.0062 & 2.1911 & 0.0054 & 0.7092 & 1939-1963 & 25 \\
\hline 3209500 & 0.209 & 0.0690 & 0.2179 & 1.8244 & 0.0054 & 0.0036 & $1970-2006$ & 37 \\
\hline 3209800 & 0.242 & 0.2726 & 0.2757 & 1.4166 & 0.0169 & 0.0796 & $1970-1981$ & 12 \\
\hline 3210000 & 0.572 & $<.0001$ & 0.4585 & 1.8614 & 0.0376 & $<.0001$ & $1942-2006$ & 63 \\
\hline 3210000 & 0.220 & 0.0746 & 0.0822 & 1.9779 & 0.0301 & 0.1002 & $1942-1975$ & 34 \\
\hline 3210000 & 0.330 & 0.0120 & 0.2265 & 1.7792 & 0.0134 & 0.0091 & $1976-2006$ & 29 \\
\hline 3211500 & 0.565 & $<.0001$ & 0.4425 & 1.2792 & 0.0184 & $<.0001$ & 1941-1992 & 52 \\
\hline 3211500 & 0.200 & 0.4208 & 0.1149 & 2.6574 & 0.0517 & 0.3379 & $1941-1950$ & 10 \\
\hline 3211500 & 0.358 & 0.0011 & 0.1119 & 1.7210 & 0.0047 & 0.0326 & 1952-1992 & 41 \\
\hline 3212000 & 0.140 & 0.3264 & 0.1131 & 2.3665 & 0.0299 & 0.1003 & $1951-1975$ & 25 \\
\hline 3212000 & 0.236 & 0.1724 & 0.1170 & 2.5338 & 0.0477 & 0.1647 & $1951-1968$ & 18 \\
\hline 3212500 & 0.592 & $<.0001$ & 0.6420 & 1.8047 & 0.0165 & $<.0001$ & $1930-2006$ & 77 \\
\hline 3212500 & 0.200 & 0.2047 & 0.0628 & 2.9326 & 0.0144 & 0.2731 & $1930-1950$ & 21 \\
\hline 3212500 & 0.126 & 0.4135 & 0.0848 & 1.7633 & 0.0052 & 0.1886 & $1985-2006$ & 22 \\
\hline 3215500 & 0.053 & 0.6371 & 0.0049 & 2.0389 & -0.0025 & 0.6714 & $1917-1975$ & 39 \\
\hline 3216000 & 0.152 & 0.4929 & 0.0688 & 2.7978 & 0.0102 & 0.4102 & 1941-1952 & 12 \\
\hline 3216350 & 0.305 & 0.0334 & 0.2217 & 0.9073 & 0.0174 & 0.0175 & 1969-1992 & 25 \\
\hline 3216400 & 0.515 & 0.0197 & 0.5774 & 1.3573 & 0.0354 & 0.0041 & $1969-1980$ & 12 \\
\hline 3216500 & 0.441 & $<.0001$ & 0.4936 & 1.3646 & 0.0148 & $<.0001$ & $1939-2006$ & 68 \\
\hline 3216500 & -0.002 & 0.9858 & 0.0000 & 2.3471 & -0.0003 & 0.9708 & $1939-1968$ & 30 \\
\hline 3216500 & -0.122 & 0.2796 & 0.0000 & 1.0977 & 0.0000 & 0.9984 & $1969-2006$ & 38 \\
\hline 3216540 & 0.007 & 0.9676 & 0.0051 & 2.0879 & 0.0122 & 0.7790 & $1974-1991$ & 18 \\
\hline
\end{tabular}


Table 2-1. Trend-test screening of annual 7-day low flows for selected long-term continuous-record streamflow-gaging stations in Kentucky for various periods of record.-Continued

[p-value, probability statistically significant if less than 0.20 ; n number of data values; $\mathrm{R}^{2}$, coefficient of determination; $<$ less than]

\begin{tabular}{|c|c|c|c|c|c|c|c|c|}
\hline \multirow{2}{*}{$\begin{array}{l}\text { Station } \\
\text { number }\end{array}$} & \multicolumn{2}{|c|}{ Trend analysis } & \multicolumn{6}{|c|}{ Regression analysis } \\
\hline & $\begin{array}{l}\text { Mann-Kendall } \\
\text { value }\end{array}$ & p-value & $\mathbf{R}^{2}$ & $\begin{array}{c}\text { Durbin-Watson } \\
\text { value }\end{array}$ & Slope & Slope p-value & Period of record & $\mathbf{n}$ \\
\hline 3216600 & -0.156 & 0.1738 & 0.0084 & 1.8852 & -0.0012 & 0.5903 & $1970-2006$ & 37 \\
\hline 3216800 & -0.273 & 0.0179 & 0.1185 & 1.5676 & -0.0268 & 0.0369 & 1958-1994 & 37 \\
\hline 3216800 & 0.022 & 0.9287 & 0.0949 & 1.9041 & 0.0823 & 0.3864 & $1958-1967$ & 10 \\
\hline 3216800 & -0.294 & 0.0317 & 0.1647 & 1.5150 & -0.0434 & 0.0357 & $1968-1994$ & 27 \\
\hline 3217000 & 0.038 & 0.6547 & 0.0070 & 1.8080 & 0.0030 & 0.5077 & $1942-2006$ & 65 \\
\hline 3217000 & 0.095 & 0.4944 & 0.0200 & 1.9468 & 0.0137 & 0.4911 & $1942-1967$ & 26 \\
\hline 3217000 & -0.131 & 0.2406 & 0.0342 & 1.6670 & -0.0102 & 0.2594 & $1968-2006$ & 39 \\
\hline 3237255 & 0.099 & 0.6222 & 0.0136 & 1.9912 & 0.0231 & 0.6913 & $1993-2006$ & 14 \\
\hline 3237255 & -0.091 & 0.6971 & 0.0609 & 2.2345 & -0.0561 & 0.4644 & $1993-2003$ & 11 \\
\hline 3237900 & -0.079 & 0.6504 & 0.0037 & 1.6741 & -0.0074 & 0.7993 & $1973-1991$ & 20 \\
\hline 3238000 & 0.008 & 0.9579 & 0.0008 & 2.1152 & 0.0007 & 0.8959 & $1942-1964$ & 23 \\
\hline 3248500 & 0.344 & 0.0002 & 0.2039 & 2.1492 & 0.0259 & 0.0005 & 1940-1997 & 55 \\
\hline 3248500 & 0.171 & 0.1443 & 0.0563 & 2.1987 & 0.0231 & 0.1634 & $1940-1975$ & 36 \\
\hline 3248500 & -0.088 & 0.5997 & 0.0016 & 1.5526 & -0.0021 & 0.8726 & 1976-1997 & 19 \\
\hline 3249500 & 0.410 & $<.0001$ & 0.2551 & 2.3098 & 0.0128 & $<.0001$ & $1929-2006$ & 59 \\
\hline 3249500 & 0.140 & 0.2179 & 0.0482 & 2.3558 & 0.0087 & 0.1854 & $1929-1973$ & 38 \\
\hline 3249500 & 0.274 & 0.0916 & 0.2033 & 2.1450 & 0.0152 & 0.0460 & $1975-2006$ & 20 \\
\hline 3250000 & 0.270 & 0.0149 & 0.1658 & 1.8215 & 0.0324 & 0.0082 & $1943-1992$ & 41 \\
\hline 3250000 & 0.099 & 0.6001 & 0.0184 & 1.9471 & 0.0320 & 0.6038 & 1943-1959 & 17 \\
\hline 3250100 & -0.211 & 0.1377 & 0.0953 & 1.3226 & -0.0391 & 0.1249 & 1969-1994 & 26 \\
\hline 3250500 & 0.153 & 0.2827 & 0.1827 & 2.3074 & 0.0103 & 0.0331 & $1939-2006$ & 25 \\
\hline 3250500 & -0.076 & 0.6290 & 0.0180 & 2.4439 & -0.0102 & 0.5623 & 1939-1959 & 21 \\
\hline 3251000 & 0.180 & 0.1015 & 0.0630 & 1.8989 & 0.0202 & 0.1002 & 1948-1991 & 44 \\
\hline 3251000 & 0.306 & 0.1308 & 0.1412 & 2.9451 & 0.0767 & 0.1514 & $1948-1963$ & 16 \\
\hline 3251200 & -0.125 & 0.5417 & 0.1126 & 2.6630 & -0.0911 & 0.2408 & $1993-2006$ & 14 \\
\hline 3251500 & 0.459 & $<.0001$ & 0.3527 & 1.7287 & 0.0139 & $<.0001$ & $1926-2006$ & 61 \\
\hline 3251500 & 0.195 & 0.0994 & 0.0556 & 1.8593 & 0.0085 & 0.1727 & $1926-1973$ & 35 \\
\hline 3251500 & -0.060 & 0.6742 & 0.0100 & 1.9438 & -0.0029 & 0.6342 & $1975-2006$ & 25 \\
\hline 3252000 & 0.292 & 0.0099 & 0.1881 & 1.5037 & 0.0154 & 0.0065 & 1954-1991 & 38 \\
\hline 3252300 & -0.099 & 0.6222 & 0.0424 & 2.2908 & -0.0447 & 0.4799 & $1993-2006$ & 14 \\
\hline
\end{tabular}


Table 2-1. Trend-test screening of annual 7-day low flows for selected long-term continuous-record streamflow-gaging stations in Kentucky for various periods of record.-Continued

[p-value, probability statistically significant if less than $0.20 ; \mathrm{n}$, number of data values; $\mathrm{R}^{2}$, coefficient of determination; $<$ less than]

\begin{tabular}{|c|c|c|c|c|c|c|c|c|}
\hline \multirow{2}{*}{$\begin{array}{l}\text { Station } \\
\text { number }\end{array}$} & \multicolumn{2}{|c|}{ Trend analysis } & \multicolumn{6}{|c|}{ Regression analysis } \\
\hline & $\begin{array}{c}\text { Mann-Kendall } \\
\text { value }\end{array}$ & p-value & $\mathbf{R}^{2}$ & $\begin{array}{c}\text { Durbin-Watson } \\
\text { value }\end{array}$ & Slope & Slope p-value & Period of record & n \\
\hline 3252500 & 0.316 & 0.0006 & 0.1208 & 1.8355 & 0.0095 & 0.0087 & 1939-1994 & 56 \\
\hline 3252500 & 0.406 & 0.0002 & 0.2070 & 2.0020 & 0.0179 & 0.0025 & $1939-1980$ & 42 \\
\hline 3252500 & 0.222 & 0.0744 & 0.0279 & 2.2262 & 0.0076 & 0.3610 & 1939-1970 & 32 \\
\hline 3253500 & 0.319 & $<.0001$ & 0.2231 & 1.8681 & 0.0092 & $<.0001$ & $1917-2006$ & 78 \\
\hline 3253500 & 0.038 & 0.7101 & 0.0040 & 2.1986 & 0.0019 & 0.6814 & $1917-1973$ & 45 \\
\hline 3253500 & -0.149 & 0.2301 & 0.0407 & 1.6992 & -0.0067 & 0.2681 & $1975-2006$ & 32 \\
\hline 3254400 & -0.071 & 0.7355 & 0.0013 & 1.8680 & 0.0056 & 0.8990 & 1969-1983 & 15 \\
\hline 3255000 & -0.028 & 0.8533 & 0.0001 & 2.7356 & 0.0002 & 0.9676 & $1941-75$ & 23 \\
\hline 3277200 & -0.250 & 0.0343 & 0.0536 & 1.9141 & -0.0039 & 0.1807 & $1972-2006$ & 35 \\
\hline 3277400 & 0.448 & 0.0200 & 0.5656 & 1.8139 & 0.0172 & 0.0012 & 1966-1998 & 15 \\
\hline 3277450 & 0.552 & $<.0001$ & 0.5298 & 2.0017 & 0.0590 & $<.0001$ & 1965-1994 & 30 \\
\hline 3277450 & 0.477 & 0.0423 & 0.3392 & 2.1837 & 0.1431 & 0.0601 & $1965-1975$ & 11 \\
\hline 3277450 & 0.477 & 0.0057 & 0.5245 & 1.4451 & 0.0470 & 0.0007 & $1977-1994$ & 18 \\
\hline 3277500 & 0.433 & $<.0001$ & 0.3734 & 2.0277 & 0.0195 & $<.0001$ & $1941-2006$ & 53 \\
\hline 3277500 & 0.232 & 0.0500 & 0.1139 & 2.0312 & 0.0153 & 0.0474 & $1941-1975$ & 35 \\
\hline 3277500 & 0.279 & 0.1175 & 0.1336 & 1.9596 & 0.0218 & 0.1491 & $1977-2006$ & 17 \\
\hline 3278000 & 0.279 & 0.1368 & 0.1291 & 1.7335 & 0.0304 & 0.1431 & $1956-1973$ & 18 \\
\hline 3278500 & 0.350 & 0.0059 & 0.2130 & 2.1025 & 0.0465 & 0.0090 & $1951-1981$ & 31 \\
\hline 3278500 & 0.000 & 1.0000 & 0.0059 & 2.0709 & 0.0189 & 0.7861 & $1951-1965$ & 15 \\
\hline 3278500 & 0.367 & 0.0476 & 0.2146 & 2.4517 & 0.0465 & 0.0707 & $1966-1981$ & 16 \\
\hline 3280000 & 0.459 & $<.0001$ & 0.4041 & 2.0756 & 0.0182 & $<.0001$ & $1930-2006$ & 68 \\
\hline 3280000 & 0.225 & 0.0498 & 0.1480 & 2.0872 & 0.0195 & 0.0187 & $1930-1975$ & 37 \\
\hline 3280000 & 0.129 & 0.3177 & 0.0284 & 2.2396 & 0.0052 & 0.3732 & $1977-2006$ & 30 \\
\hline 3280000 & 0.093 & 0.4557 & 0.0673 & 2.1024 & 0.0146 & 0.1516 & $1930-1970$ & 32 \\
\hline 3280000 & 0.031 & 0.8186 & 0.0425 & 2.1507 & 0.0137 & 0.3024 & 1930-1965 & 27 \\
\hline 3280000 & -0.022 & 0.8879 & 0.0315 & 2.2407 & 0.0141 & 0.4294 & $1930-1960$ & 22 \\
\hline 3280600 & 0.163 & 0.1771 & 0.0016 & 2.5023 & 0.0038 & 0.8207 & 1959-1992 & 34 \\
\hline 3280600 & -0.092 & 0.7165 & 0.0004 & 1.8509 & -0.0036 & 0.9590 & $1959-1968$ & 10 \\
\hline 3280700 & 0.306 & 0.0022 & 0.2016 & 1.9195 & 0.0199 & 0.0014 & 1959-2006 & 48 \\
\hline 3280700 & -0.004 & 0.9729 & 0.0022 & 2.0910 & 0.0030 & 0.8038 & 1959-1989 & 31 \\
\hline
\end{tabular}


Table 2-1. Trend-test screening of annual 7-day low flows for selected long-term continuous-record streamflow-gaging stations in Kentucky for various periods of record.-Continued

[p-value, probability statistically significant if less than 0.20 ; n number of data values; $\mathrm{R}^{2}$, coefficient of determination; $<$ less than]

\begin{tabular}{|c|c|c|c|c|c|c|c|c|}
\hline \multirow{2}{*}{$\begin{array}{l}\text { Station } \\
\text { number }\end{array}$} & \multicolumn{2}{|c|}{ Trend analysis } & \multicolumn{6}{|c|}{ Regression analysis } \\
\hline & $\begin{array}{c}\text { Mann-Kendall } \\
\text { value }\end{array}$ & p-value & $\mathbf{R}^{2}$ & $\begin{array}{c}\text { Durbin-Watson } \\
\text { value }\end{array}$ & Slope & Slope p-value & Period of record & $\mathbf{n}$ \\
\hline 3280700 & -0.206 & 0.2487 & 0.0580 & 1.5946 & -0.0178 & 0.3516 & $1990-2006$ & 17 \\
\hline 3280900 & 0.209 & 0.2983 & 0.1717 & 2.6751 & 0.0326 & 0.1408 & $1962-1975$ & 14 \\
\hline 3281000 & 0.295 & 0.0006 & 0.2557 & 1.4338 & 0.0163 & $<.0001$ & $1932-2006$ & 64 \\
\hline 3281000 & -0.076 & 0.6290 & 0.0277 & 2.1289 & -0.0161 & 0.4707 & $1932-1960$ & 21 \\
\hline 3281000 & -0.162 & 0.1319 & 0.0394 & 2.1526 & -0.0042 & 0.2077 & $1962-2006$ & 42 \\
\hline 3281040 & 0.071 & 0.6022 & 0.0121 & 2.2398 & 0.0061 & 0.5855 & $1974-2000$ & 27 \\
\hline 3281040 & -0.200 & 0.2799 & 0.0963 & 2.8957 & -0.0251 & 0.2421 & 1974-1989 & 16 \\
\hline 3281040 & -0.564 & 0.0158 & 0.3654 & 2.5720 & -0.0843 & 0.0489 & $1990-2000$ & 11 \\
\hline 3281100 & 0.170 & 0.1184 & 0.0683 & 1.8945 & 0.0095 & 0.0989 & $1966-2006$ & 41 \\
\hline 3281100 & -0.203 & 0.1648 & 0.1193 & 1.7127 & -0.0208 & 0.0983 & 1966-1989 & 24 \\
\hline 3281100 & -0.214 & 0.2319 & 0.0239 & 1.9931 & -0.0104 & 0.5536 & $1990-2006$ & 17 \\
\hline 3281500 & 0.198 & 0.0141 & 0.0766 & 1.7623 & 0.0094 & 0.0186 & $1926-2006$ & 72 \\
\hline 3281500 & 0.004 & 0.9741 & 0.0004 & 1.7722 & -0.0015 & 0.9094 & $1926-1966$ & 32 \\
\hline 3281500 & 0.004 & 0.9721 & 0.0014 & 2.0183 & -0.0018 & 0.8203 & $1967-2006$ & 40 \\
\hline 3282000 & 0.298 & 0.0002 & 0.2388 & 1.6454 & 0.0097 & $<.0001$ & $1927-2006$ & 72 \\
\hline 3282000 & 0.278 & 0.0104 & 0.1323 & 1.5768 & 0.0121 & 0.0194 & $1941-1960$ & 41 \\
\hline 3282000 & -0.028 & 0.8304 & 0.0006 & 1.9902 & 0.0009 & 0.8954 & $1977-2006$ & 30 \\
\hline 3282040 & -0.090 & 0.6688 & 0.0623 & 2.1975 & -0.0646 & 0.4110 & 1994-2006 & 13 \\
\hline 3282500 & 0.148 & 0.1267 & 0.0364 & 1.8706 & 0.0123 & 0.1753 & $1955-2006$ & 52 \\
\hline 3282500 & 0.256 & 0.1583 & 0.2149 & 3.1624 & 0.0797 & 0.0609 & $1955-1971$ & 17 \\
\hline 3282500 & -0.268 & 0.0246 & 0.1386 & 2.1945 & -0.0339 & 0.0276 & $1972-2006$ & 35 \\
\hline 3283000 & 0.185 & 0.2848 & 0.2139 & 2.3570 & 0.0608 & 0.0462 & $1955-1973$ & 19 \\
\hline 3283500 & 0.154 & 0.0608 & 0.0601 & 1.8501 & 0.0045 & 0.0423 & $1932-2006$ & 69 \\
\hline 3283500 & -0.138 & 0.3553 & 0.0231 & 2.1572 & -0.0084 & 0.4884 & $1932-60$ & 23 \\
\hline 3283500 & 0.121 & 0.2366 & 0.0464 & 1.6299 & 0.0055 & 0.1505 & $1961-2006$ & 46 \\
\hline 3284000 & 0.302 & $<.0001$ & 0.2229 & 1.9792 & 0.0060 & $<.0001$ & $1909-2006$ & 96 \\
\hline 3284000 & -0.003 & 0.9748 & 0.0005 & 2.2147 & 0.0005 & 0.8754 & $1909-1960$ & 52 \\
\hline 3284000 & 0.013 & 0.9213 & 0.0004 & 1.8714 & 0.0007 & 0.9160 & $1977-2006$ & 28 \\
\hline 3284300 & 0.019 & 0.9211 & 0.1418 & 1.7444 & 0.0545 & 0.1665 & $1969-1983$ & 15 \\
\hline 3284500 & 0.323 & 0.0073 & 0.1246 & 1.9493 & 0.0080 & 0.0406 & $1941-2006$ & 34 \\
\hline
\end{tabular}


Table 2-1. Trend-test screening of annual 7-day low flows for selected long-term continuous-record streamflow-gaging stations in Kentucky for various periods of record.-Continued

[p-value, probability statistically significant if less than $0.20 ; \mathrm{n}$, number of data values; $\mathrm{R}^{2}$, coefficient of determination; $<$ less than]

\begin{tabular}{|c|c|c|c|c|c|c|c|c|}
\hline \multirow{2}{*}{$\begin{array}{l}\text { Station } \\
\text { number }\end{array}$} & \multicolumn{2}{|c|}{ Trend analysis } & \multicolumn{6}{|c|}{ Regression analysis } \\
\hline & $\begin{array}{c}\text { Mann-Kendall } \\
\text { value }\end{array}$ & $p$-value & $\mathbf{R}^{2}$ & $\begin{array}{l}\text { Durbin-Watson } \\
\text { value }\end{array}$ & Slope & Slope p-value & Period of record & n \\
\hline 3284500 & 0.084 & 0.6037 & 0.0003 & 2.2038 & 0.0011 & 0.9392 & $1941-1960$ & 20 \\
\hline 3285000 & 0.302 & 0.0005 & 0.2082 & 1.7620 & 0.0251 & 0.0002 & 1944-2006 & 63 \\
\hline 3285000 & 0.164 & 0.2264 & 0.0677 & 2.0367 & 0.0320 & 0.1810 & $1944-1971$ & 28 \\
\hline 3285000 & -0.050 & 0.6700 & 0.0004 & 1.6760 & -0.0015 & 0.9117 & $1972-2006$ & 35 \\
\hline 3286500 & -0.103 & 0.6255 & 0.0013 & 1.9696 & -0.0031 & 0.9081 & $1994-2006$ & 13 \\
\hline 3287000 & -0.085 & 0.5092 & 0.0002 & 2.1158 & 0.0005 & 0.9373 & $1977-2006$ & 30 \\
\hline 3287500 & -0.094 & 0.4645 & 0.0067 & 1.9743 & -0.0029 & 0.6674 & $1977-2006$ & 30 \\
\hline 3288000 & 0.361 & 0.0006 & 0.1959 & 1.7155 & 0.0268 & 0.0026 & 1951-1999 & 44 \\
\hline 3288000 & 0.292 & 0.0469 & 0.2951 & 1.7849 & 0.0686 & 0.0050 & $1951-1975$ & 24 \\
\hline 3288000 & -0.121 & 0.4553 & 0.0001 & 2.0609 & -0.0009 & 0.9636 & 1975-1999 & 20 \\
\hline 3288500 & 0.331 & 0.0525 & 0.2387 & 2.5095 & 0.0455 & 0.0338 & $1954-1972$ & 19 \\
\hline 3289000 & 0.421 & $<.0001$ & 0.3509 & 1.5066 & 0.0365 & $<.0001$ & $1951-2006$ & 50 \\
\hline 3289000 & 0.379 & 0.0131 & 0.2861 & 2.0097 & 0.0842 & 0.0071 & $1951-1974$ & 24 \\
\hline 3289000 & -0.092 & 0.5084 & 0.0481 & 1.9848 & -0.0076 & 0.2816 & $1975-99$ & 26 \\
\hline 3289300 & -0.127 & 0.3979 & 0.0635 & 0.9467 & -0.0063 & 0.2460 & $1984-2006$ & 23 \\
\hline 3289500 & 0.417 & $<.0001$ & 0.2529 & 1.3372 & 0.0087 & $<.0001$ & $1917-2006$ & 64 \\
\hline 3289500 & 0.236 & 0.0578 & 0.0005 & 1.4038 & -0.0006 & 0.9070 & $1917-1970$ & 32 \\
\hline 3289500 & 0.030 & 0.8078 & 0.0031 & 1.7343 & 0.0010 & 0.7612 & $1971-2006$ & 32 \\
\hline 3289500 & 0.083 & 0.5792 & 0.0626 & 1.8069 & 0.0067 & 0.2495 & $1980-2006$ & 23 \\
\hline 3290500 & 0.017 & 0.8337 & 0.0000 & 1.9077 & 0.0001 & 0.9599 & $1927-2006$ & 74 \\
\hline 3290500 & -0.117 & 0.3629 & 0.0113 & 1.9885 & -0.0037 & 0.5755 & $1977-2006$ & 30 \\
\hline 3291000 & -0.064 & 0.6530 & 0.0005 & 1.5365 & 0.0014 & 0.8973 & $1943-1975$ & 33 \\
\hline 3291500 & 0.285 & 0.0020 & 0.1550 & 1.4594 & 0.0199 & 0.0020 & $1917-2006$ & 59 \\
\hline 3291500 & -0.104 & 0.3990 & 0.0444 & 1.7578 & -0.0167 & 0.2176 & $1917-1971$ & 36 \\
\hline 3291500 & -0.095 & 0.5260 & 0.0322 & 2.3919 & -0.0124 & 0.4128 & $1972-2006$ & 23 \\
\hline 3292460 & -0.674 & $<.0001$ & 0.7174 & 1.8036 & -0.0951 & $<.0001$ & 1969-1994 & 26 \\
\hline 3292500 & 0.551 & $<.0001$ & 0.4368 & 1.4362 & 0.0270 & $<.0001$ & $1946-2006$ & 41 \\
\hline 3292500 & -0.079 & 0.6887 & 0.0132 & 1.7374 & -0.0190 & 0.6831 & $1946-1962$ & 15 \\
\hline 3292500 & -0.007 & 0.9697 & 0.0211 & 1.5332 & -0.0034 & 0.5655 & $1980-2006$ & 18 \\
\hline 3293000 & 0.055 & 0.5460 & 0.0124 & 0.8888 & 0.0038 & 0.4044 & $1946-2006$ & 58 \\
\hline
\end{tabular}


Table 2-1. Trend-test screening of annual 7-day low flows for selected long-term continuous-record streamflow-gaging stations in Kentucky for various periods of record.-Continued

[p-value, probability statistically significant if less than 0.20 ; n number of data values; $\mathrm{R}^{2}$, coefficient of determination; $<$ less than]

\begin{tabular}{|c|c|c|c|c|c|c|c|c|}
\hline \multirow{2}{*}{$\begin{array}{l}\text { Station } \\
\text { number }\end{array}$} & \multicolumn{2}{|c|}{ Trend analysis } & \multicolumn{6}{|c|}{ Regression analysis } \\
\hline & $\begin{array}{c}\text { Mann-Kendall } \\
\text { value }\end{array}$ & p-value & $\mathbf{R}^{2}$ & $\begin{array}{c}\text { Durbin-Watson } \\
\text { value }\end{array}$ & Slope & Slope p-value & Period of record & $\mathbf{n}$ \\
\hline 3294500 & -0.219 & 0.0562 & 0.0354 & 1.9485 & -0.0029 & 0.2649 & $1929-2006$ & 37 \\
\hline 3294500 & -0.219 & 0.0562 & 0.0354 & 1.9485 & -0.0029 & 0.2649 & $1970-2006$ & 37 \\
\hline 3295000 & 0.293 & 0.0934 & 0.1744 & 2.0514 & 0.0561 & 0.0669 & $1954-1973$ & 20 \\
\hline 3295400 & -0.159 & 0.3918 & 0.0168 & 1.9003 & -0.0211 & 0.6321 & $1991-2006$ & 16 \\
\hline 3295500 & 0.458 & $<.0001$ & 0.3739 & 1.8855 & 0.0621 & $<.0001$ & $1940-1982$ & 43 \\
\hline 3295500 & 0.109 & 0.4547 & 0.0170 & 2.2380 & 0.0178 & 0.5087 & $1940-67$ & 28 \\
\hline 3295500 & 0.230 & 0.2344 & 0.0830 & 1.5161 & 0.0351 & 0.2977 & $1968-1982$ & 15 \\
\hline 3295890 & 0.214 & 0.1482 & 0.0900 & 2.3528 & 0.0519 & 0.1544 & $1983-2006$ & 24 \\
\hline 3297500 & 0.047 & 0.7964 & 0.0001 & 2.2935 & 0.0007 & 0.9666 & $1955-1974$ & 20 \\
\hline 3297845 & -0.130 & 0.6165 & 0.0151 & 2.0145 & -0.0264 & 0.7186 & 1981-1991 & 11 \\
\hline 3297900 & 0.103 & 0.6255 & 0.0063 & 2.4093 & 0.0119 & 0.7962 & $1993-2006$ & 13 \\
\hline 3298000 & 0.406 & $<.0001$ & 0.2946 & 1.6338 & 0.0337 & $<.0001$ & $1946-2006$ & 58 \\
\hline 3298000 & 0.353 & 0.0115 & 0.1623 & 2.2280 & 0.0422 & 0.0273 & $1946-1975$ & 30 \\
\hline 3298000 & -0.011 & 0.9369 & 0.0012 & 1.2962 & 0.0036 & 0.8591 & $1976-2006$ & 28 \\
\hline 3298500 & 0.588 & $<.0001$ & 0.5542 & 1.8032 & 0.0402 & $<.0001$ & $1940-2006$ & 67 \\
\hline 3298500 & 0.489 & $<.0001$ & 0.3994 & 1.9087 & 0.0540 & $<.0001$ & $1940-82$ & 43 \\
\hline 3298500 & 0.189 & 0.1602 & 0.0907 & 1.9580 & 0.0375 & 0.1194 & $1940-67$ & 28 \\
\hline 3298500 & 0.178 & 0.2346 & 0.1365 & 2.3034 & 0.0148 & 0.0827 & $1984-2006$ & 23 \\
\hline 3298550 & -0.169 & 0.4087 & 0.0072 & 1.1163 & -0.0096 & 0.7726 & $1993-2006$ & 14 \\
\hline 3299000 & 0.221 & 0.0199 & 0.1157 & 1.4690 & 0.0247 & 0.0118 & $1939-1992$ & 54 \\
\hline 3299000 & 0.223 & 0.1125 & 0.1128 & 1.4109 & 0.0507 & 0.0868 & $1939-1965$ & 27 \\
\hline 3299000 & -0.092 & 0.5044 & 0.0699 & 1.9541 & -0.0314 & 0.1828 & 1966-1992 & 27 \\
\hline 3300000 & 0.376 & 0.0364 & 0.2120 & 2.2938 & 0.0692 & 0.0473 & 1954-1972 & 19 \\
\hline 3300400 & -0.169 & 0.1676 & 0.0665 & 1.6019 & -0.0268 & 0.1472 & $1974-2006$ & 33 \\
\hline 3300400 & -0.096 & 0.5920 & 0.0164 & 1.9606 & -0.0236 & 0.6244 & $1990-2006$ & 17 \\
\hline 3301000 & 0.341 & 0.0019 & 0.1315 & 1.7870 & 0.0138 & 0.0215 & $1941-2006$ & 40 \\
\hline 3301000 & 0.255 & 0.0962 & 0.0810 & 1.9719 & 0.0341 & 0.1994 & $1941-1962$ & 22 \\
\hline 3301000 & 0.294 & 0.0883 & 0.0300 & 1.5369 & 0.0056 & 0.4916 & $1963-2006$ & 18 \\
\hline 3301500 & 0.219 & 0.0088 & 0.1328 & 1.6823 & 0.0096 & 0.0024 & $1940-2006$ & 67 \\
\hline 3301500 & 0.154 & 0.2703 & 0.0556 & 1.8103 & 0.0173 & 0.2464 & $1940-65$ & 26 \\
\hline
\end{tabular}


Table 2-1. Trend-test screening of annual 7-day low flows for selected long-term continuous-record streamflow-gaging stations in Kentucky for various periods of record.-Continued

[p-value, probability statistically significant if less than $0.20 ; \mathrm{n}$, number of data values; $\mathrm{R}^{2}$, coefficient of determination; $<$ less than]

\begin{tabular}{|c|c|c|c|c|c|c|c|c|}
\hline \multirow{2}{*}{$\begin{array}{l}\text { Station } \\
\text { number }\end{array}$} & \multicolumn{2}{|c|}{ Trend analysis } & \multicolumn{6}{|c|}{ Regression analysis } \\
\hline & $\begin{array}{l}\text { Mann-Kendall } \\
\text { value }\end{array}$ & p-value & $\mathbf{R}^{2}$ & $\begin{array}{c}\text { Durbin-Watson } \\
\text { value }\end{array}$ & Slope & Slope $p$-value & Period of record & n \\
\hline 3301500 & -0.174 & 0.1686 & 0.0010 & 1.7508 & -0.0011 & 0.8429 & $1966-2006$ & 31 \\
\hline 3302000 & 0.329 & 0.0003 & 0.3177 & 0.6109 & 0.0139 & $<.0001$ & $1946-2006$ & 58 \\
\hline 3302000 & 0.600 & $<.0001$ & 0.4708 & 1.0728 & 0.0429 & 0.0002 & $1970-2006$ & 35 \\
\hline 3303280 & 0.067 & 0.6049 & 0.0147 & 2.1206 & 0.0028 & 0.5240 & $1977-2006$ & 30 \\
\hline 3303500 & 0.294 & 0.2115 & 0.1011 & 2.7413 & 0.0171 & 0.3406 & $1942-52$ & 11 \\
\hline 3304500 & 0.000 & 1.0000 & 0.0005 & 2.3478 & -0.0013 & 0.9300 & 1953-1971 & 19 \\
\hline 3305000 & 0.340 & 0.0454 & 0.1797 & 1.8744 & 0.0471 & 0.0555 & $1953-1973$ & 21 \\
\hline 3306000 & -0.048 & 0.7627 & 0.0810 & 1.9719 & 0.0341 & 0.1994 & 1970-1994 & 21 \\
\hline 3306500 & 0.352 & 0.0025 & 0.1961 & 1.1424 & 0.0201 & 0.0068 & $1941-2006$ & 36 \\
\hline 3306500 & 0.101 & 0.4528 & 0.0083 & 1.2778 & 0.0059 & 0.6457 & 1941-1968 & 28 \\
\hline 3307000 & 0.248 & 0.0032 & 0.1165 & 1.7065 & 0.0075 & 0.0050 & $1941-2006$ & 66 \\
\hline 3307000 & 0.382 & 0.0005 & 0.2452 & 1.4059 & 0.0174 & 0.0012 & $1941-1980$ & 40 \\
\hline 3307000 & -0.058 & 0.6754 & 0.0076 & 2.2924 & -0.0048 & 0.6729 & 1981-2006 & 26 \\
\hline 3307100 & 0.333 & 0.1797 & 0.2396 & 2.6850 & 0.0427 & 0.1511 & $1966-75$ & 10 \\
\hline 3307500 & 0.306 & 0.0374 & 0.0890 & 2.0047 & 0.0221 & 0.1093 & $1943-72$ & 30 \\
\hline 3308500 & 0.326 & $<.0001$ & 0.2229 & 1.0437 & 0.0043 & $<.0001$ & $1916-2006$ & 76 \\
\hline 3308500 & -0.010 & 0.9257 & 0.0014 & 1.0981 & -0.0005 & 0.8209 & 1916-1968 & 40 \\
\hline 3308500 & -0.277 & 0.0191 & 0.1461 & 1.9382 & -0.0048 & 0.0234 & $1970-2006$ & 35 \\
\hline 3309000 & 0.345 & 0.1391 & 0.3292 & 2.3139 & 0.0199 & 0.0649 & $1940-1950$ & 11 \\
\hline 3309500 & 0.052 & 0.7725 & 0.1073 & 1.3526 & 0.0421 & 0.1994 & $1955-1971$ & 17 \\
\hline 3310000 & 0.173 & 0.1775 & 0.0831 & 1.4249 & 0.0292 & 0.1157 & $1943-1973$ & 31 \\
\hline 3310300 & 0.033 & 0.7475 & 0.0021 & 1.6718 & 0.0005 & 0.7618 & $1961-2006$ & 46 \\
\hline 3310300 & 0.484 & 0.0028 & 0.4149 & 1.9992 & 0.0168 & 0.0022 & 1961-1980 & 20 \\
\hline 3310300 & -0.040 & 0.7745 & 0.0022 & 1.6095 & -0.0008 & 0.8210 & $1981-2006$ & 26 \\
\hline 3310400 & -0.014 & 0.9056 & 0.0007 & 1.3126 & -0.0004 & 0.8845 & 1961-1994 & 34 \\
\hline 3310500 & 0.177 & 0.2157 & 0.0575 & 1.2579 & 0.0055 & 0.2481 & 1938-1962 & 25 \\
\hline 3310500 & -0.022 & 0.9287 & 0.0045 & 1.7564 & 0.0029 & 0.8532 & 1938-1947 & 10 \\
\hline 3310500 & 0.115 & 0.5521 & 0.0001 & 1.1222 & 0.0004 & 0.9757 & 1948-1962 & 15 \\
\hline 3311000 & -0.136 & 0.1441 & 0.0051 & 2.1700 & -0.0047 & 0.6061 & 1931-2004 & 55 \\
\hline 3311000 & 0.236 & 0.3115 & 0.0669 & 2.3520 & 0.0062 & 0.4424 & $1931-1950$ & 11 \\
\hline
\end{tabular}


Table 2-1. Trend-test screening of annual 7-day low flows for selected long-term continuous-record streamflow-gaging stations in Kentucky for various periods of record.-Continued

[p-value, probability statistically significant if less than $0.20 ; \mathrm{n}$, number of data values; $\mathrm{R}^{2}$, coefficient of determination; $<$ less than]

\begin{tabular}{|c|c|c|c|c|c|c|c|c|}
\hline \multirow{2}{*}{$\begin{array}{l}\text { Station } \\
\text { number }\end{array}$} & \multicolumn{2}{|c|}{ Trend analysis } & \multicolumn{6}{|c|}{ Regression analysis } \\
\hline & $\begin{array}{c}\text { Mann-Kendall } \\
\text { value }\end{array}$ & p-value & $\mathbf{R}^{2}$ & $\begin{array}{c}\text { Durbin-Watson } \\
\text { value }\end{array}$ & Slope & Slope p-value & Period of record & $\mathbf{n}$ \\
\hline 3311000 & 0.189 & 0.0804 & 0.0672 & 2.4787 & 0.0303 & 0.0973 & 1964-2004 & 42 \\
\hline 3311500 & 0.336 & 0.0002 & 0.2373 & 1.2603 & 0.0053 & $<.0001$ & 1926-1992 & 59 \\
\hline 3311500 & 0.099 & 0.4531 & 0.0208 & 1.0183 & 0.0025 & 0.4559 & $1926-1962$ & 29 \\
\hline 3311500 & -0.265 & 0.0768 & 0.1658 & 2.7835 & -0.0088 & 0.0538 & 1970-1992 & 23 \\
\hline 3311600 & -0.130 & 0.4141 & 0.0589 & 2.1655 & -0.0115 & 0.2890 & 1974-1994 & 21 \\
\hline 3312000 & 0.294 & 0.0676 & 0.2255 & 0.8140 & 0.0672 & 0.0296 & $1951-1971$ & 21 \\
\hline 3312000 & 0.277 & 0.2906 & 0.0538 & 0.7649 & 0.0779 & 0.5189 & $1951-1960$ & 10 \\
\hline 3312000 & -0.127 & 0.5858 & 0.1337 & 1.9712 & -0.0460 & 0.2687 & 1961-1971 & 11 \\
\hline 3312500 & 0.091 & 0.5351 & 0.0216 & 1.3095 & 0.0043 & 0.4935 & $1940-1963$ & 24 \\
\hline 3312765 & -0.111 & 0.6547 & 0.0253 & 2.7664 & -0.0138 & 0.6607 & $1993-2002$ & 10 \\
\hline 3313000 & -0.037 & 0.7361 & 0.0049 & 2.1052 & -0.0031 & 0.6645 & $1943-1994$ & 41 \\
\hline 3313000 & 0.156 & 0.5312 & 0.0045 & 2.2480 & 0.0012 & 0.8540 & $1943-1963$ & 10 \\
\hline 3313000 & 0.237 & 0.0661 & 0.0205 & 2.1837 & 0.0128 & 0.4506 & $1965-1994$ & 30 \\
\hline 3313500 & 0.689 & $<.0001$ & 0.5950 & 2.2839 & 0.0681 & $<.0001$ & $1952-1972$ & 21 \\
\hline 3313500 & 0.610 & 0.0011 & 0.5052 & 2.3156 & 0.0784 & 0.0020 & $1952-1967$ & 16 \\
\hline 3313700 & -0.143 & 0.2274 & 0.0166 & 1.5039 & -0.0087 & 0.4610 & 1970-2004 & 35 \\
\hline 3313700 & -0.244 & 0.3252 & 0.2796 & 1.1628 & -0.0404 & 0.1161 & 1970-1979 & 10 \\
\hline 3313700 & -0.257 & 0.1815 & 0.0411 & 2.1576 & -0.0172 & 0.4688 & $1990-2004$ & 15 \\
\hline 3314000 & 0.299 & 0.0204 & 0.1635 & 1.0590 & 0.0105 & 0.0267 & $1942-1971$ & 30 \\
\hline 3314000 & 0.059 & 0.7263 & 0.0131 & 1.0524 & 0.0047 & 0.6414 & $1942-1960$ & 19 \\
\hline 3314000 & 0.418 & 0.0734 & 0.3506 & 1.4895 & 0.0345 & 0.0549 & 1961-1971 & 11 \\
\hline 3314500 & 0.252 & 0.0048 & 0.1385 & 1.1852 & 0.0053 & 0.0037 & $1940-2006$ & 59 \\
\hline 3314500 & 0.087 & 0.5516 & 0.0133 & 1.0500 & 0.0038 & 0.5917 & $1940-1963$ & 24 \\
\hline 3314500 & -0.112 & 0.3503 & 0.0030 & 1.4309 & -0.0011 & 0.7595 & $1965-2006$ & 34 \\
\hline 3315500 & 0.280 & 0.0019 & 0.1357 & 0.9901 & 0.0047 & 0.0044 & $1939-1992$ & 58 \\
\hline 3315500 & 0.101 & 0.4874 & 0.0125 & 0.9020 & 0.0031 & 0.6036 & $1939-1962$ & 24 \\
\hline 3315500 & -0.379 & 0.0056 & 0.2919 & 2.1099 & -0.0111 & 0.0036 & 1970-1992 & 27 \\
\hline 3316000 & 0.281 & 0.0272 & 0.1570 & 1.2031 & 0.0516 & 0.0247 & 1941-1972 & 32 \\
\hline 3316000 & -0.061 & 0.7087 & 0.0072 & 1.3861 & -0.0177 & 0.7139 & 1941-1961 & 21 \\
\hline 3316000 & 0.257 & 0.2743 & 0.2032 & 1.9868 & 0.0377 & 0.1640 & $1962-1972$ & 11 \\
\hline
\end{tabular}


Table 2-1. Trend-test screening of annual 7-day low flows for selected long-term continuous-record streamflow-gaging stations in Kentucky for various periods of record.-Continued

[p-value, probability statistically significant if less than $0.20 ; \mathrm{n}$, number of data values; $\mathrm{R}^{2}$, coefficient of determination; $<$ less than]

\begin{tabular}{|c|c|c|c|c|c|c|c|c|}
\hline \multirow{2}{*}{$\begin{array}{l}\text { Station } \\
\text { number }\end{array}$} & \multicolumn{2}{|c|}{ Trend analysis } & \multicolumn{6}{|c|}{ Regression analysis } \\
\hline & $\begin{array}{l}\text { Mann-Kendall } \\
\text { value }\end{array}$ & p-value & $\mathbf{R}^{2}$ & $\begin{array}{l}\text { Durbin-Watson } \\
\text { value }\end{array}$ & Slope & Slope p-value & Period of record & $\mathbf{n}$ \\
\hline 3316500 & 0.326 & 0.0016 & 0.1524 & 1.5161 & 0.0045 & 0.0080 & $1941-2006$ & 45 \\
\hline 3316500 & 0.506 & 0.0458 & 0.5533 & 1.8951 & 0.0255 & 0.0136 & 1941-1962 & 10 \\
\hline 3316500 & -0.206 & 0.1397 & 0.1034 & 2.3401 & -0.0058 & 0.1092 & $1970-2006$ & 26 \\
\hline 3317000 & 0.216 & 0.1832 & 0.0239 & 1.1229 & 0.0051 & 0.5152 & $1940-1959$ & 20 \\
\hline 3317500 & 0.018 & 0.9154 & 0.0000 & 2.4233 & 0.0004 & 0.9896 & $1955-1973$ & 19 \\
\hline 3318000 & 0.294 & 0.2115 & 0.2498 & 1.6441 & 0.0394 & 0.1175 & 1941-1951 & 11 \\
\hline 3318200 & 0.107 & 0.6246 & 0.0218 & 1.9139 & 0.0276 & 0.6146 & 1958-1971 & 14 \\
\hline 3318500 & 0.277 & 0.0074 & 0.1977 & 1.9877 & 0.0097 & 0.0022 & 1950-1994 & 45 \\
\hline 3318500 & -0.111 & 0.6547 & 0.1275 & 1.4333 & -0.0328 & 0.3112 & $1950-1959$ & 10 \\
\hline 3318500 & 0.059 & 0.6247 & 0.0232 & 2.5017 & 0.0037 & 0.3894 & 1961-1994 & 34 \\
\hline 3318800 & -0.013 & 0.9214 & 0.0005 & 2.1526 & 0.0021 & 0.8941 & 1958-1992 & 35 \\
\hline 3319000 & 0.443 & $<.0001$ & 0.4415 & 1.3955 & 0.0111 & $<.0001$ & $1941-2004$ & 54 \\
\hline 3319000 & 0.188 & 0.2626 & 0.0305 & 1.1812 & 0.0065 & 0.4749 & 1941-1959 & 19 \\
\hline 3319000 & 0.020 & 0.8705 & 0.0074 & 2.3709 & 0.0013 & 0.6275 & $1961-2004$ & 34 \\
\hline 3320000 & 0.221 & 0.0047 & 0.1071 & 1.4206 & 0.0034 & 0.0039 & $1931-2006$ & 76 \\
\hline 3320000 & -0.108 & 0.4092 & 0.0013 & 0.9769 & -0.0008 & 0.8517 & 1931-1959 & 29 \\
\hline 3320000 & -0.279 & 0.0150 & 0.1143 & 2.1683 & -0.0074 & 0.0407 & $1970-2006$ & 37 \\
\hline 3320500 & 0.255 & 0.0042 & 0.1272 & 1.8549 & 0.0221 & 0.0035 & $1942-2006$ & 65 \\
\hline 3320500 & 0.043 & 0.8142 & 0.0073 & 1.0423 & 0.0172 & 0.7283 & $1942-1960$ & 19 \\
\hline 3320500 & 0.006 & 0.9664 & 0.0008 & 1.4099 & 0.0036 & 0.8860 & $1942-1970$ & 29 \\
\hline 3320500 & 0.251 & 0.0351 & 0.1255 & 1.4815 & 0.0358 & 0.0269 & $1942-1980$ & 39 \\
\hline 3320500 & 0.209 & 0.0476 & 0.0825 & 2.0865 & 0.0244 & 0.0529 & $1961-2006$ & 46 \\
\hline 3320500 & 0.049 & 0.6808 & 0.0084 & 2.2711 & 0.0095 & 0.5960 & $1971-2006$ & 36 \\
\hline 3320500 & 0.226 & 0.1135 & 0.1241 & 2.4729 & 0.0534 & 0.0775 & 1981-2006 & 26 \\
\hline 3321350 & 0.112 & 0.5887 & 0.0254 & 2.6316 & 0.0373 & 0.5707 & $1969-1983$ & 15 \\
\hline 3322000 & 0.281 & 0.0218 & 0.1092 & 1.8952 & 0.0058 & 0.0603 & $1942-74$ & 33 \\
\hline 3322360 & 0.139 & 0.5035 & 0.0078 & 2.2743 & 0.0026 & 0.7365 & 1974-1994 & 17 \\
\hline 3383000 & 0.261 & 0.0027 & 0.1853 & 1.7542 & 0.0240 & 0.0004 & $1942-2006$ & 64 \\
\hline 3383000 & 0.285 & 0.0227 & 0.1486 & 1.6070 & 0.0448 & 0.0244 & $1942-1975$ & 34 \\
\hline 3383000 & -0.018 & 0.8865 & 0.0002 & 2.3308 & 0.0011 & 0.9447 & $1976-2006$ & 30 \\
\hline
\end{tabular}


Table 2-1. Trend-test screening of annual 7-day low flows for selected long-term continuous-record streamflow-gaging stations in Kentucky for various periods of record.-Continued

[p-value, probability statistically significant if less than $0.20 ; \mathrm{n}$, number of data values; $\mathrm{R}^{2}$, coefficient of determination; $<$ less than]

\begin{tabular}{|c|c|c|c|c|c|c|c|c|}
\hline \multirow{2}{*}{$\begin{array}{l}\text { Station } \\
\text { number }\end{array}$} & \multicolumn{2}{|c|}{ Trend analysis } & \multicolumn{6}{|c|}{ Regression analysis } \\
\hline & $\begin{array}{l}\text { Mann-Kendall } \\
\text { value }\end{array}$ & p-value & $\mathbf{R}^{2}$ & $\begin{array}{c}\text { Durbin-Watson } \\
\text { value }\end{array}$ & Slope & Slope p-value & Period of record & $\mathbf{n}$ \\
\hline 3384500 & 0.367 & 0.1183 & 0.1838 & 2.7231 & 0.0254 & 0.1882 & $1942-1952$ & 11 \\
\hline 3400500 & 0.201 & 0.0358 & 0.1252 & 1.8532 & 0.0055 & 0.0101 & 1941-1992 & 52 \\
\hline 3400500 & 0.195 & 0.2297 & 0.0983 & 1.9555 & 0.0137 & 0.1784 & $1941-1960$ & 20 \\
\hline 3400500 & 0.141 & 0.2563 & 0.0014 & 2.3253 & 0.0012 & 0.8669 & 1971-1992 & 32 \\
\hline 3400800 & 0.220 & 0.0829 & 0.1053 & 1.9566 & 0.0127 & 0.0750 & $1972-2004$ & 31 \\
\hline 3400800 & -0.055 & 0.7115 & 0.0619 & 2.2811 & -0.0030 & 0.2524 & $1980-2004$ & 23 \\
\hline 3400800 & -0.271 & 0.1993 & 0.1874 & 2.1973 & -0.0094 & 0.1395 & $1990-2004$ & 13 \\
\hline 3400990 & 0.282 & 0.1795 & 0.1854 & 2.2913 & 0.0168 & 0.1418 & $1980-2006$ & 13 \\
\hline 3401000 & 0.367 & $<.0001$ & 0.2766 & 1.9550 & 0.0085 & $<.0001$ & $1941-2005$ & 65 \\
\hline 3401000 & 0.313 & 0.0057 & 0.1846 & 1.9378 & 0.0121 & 0.0071 & 1941-1978 & 38 \\
\hline 3401000 & 0.200 & 0.1206 & 0.0814 & 1.8333 & 0.0100 & 0.1264 & $1941-1970$ & 30 \\
\hline 3401000 & 0.021 & 0.8967 & 0.0000 & 2.0425 & 0.0004 & 0.9771 & $1941-1960$ & 20 \\
\hline 3401000 & 0.046 & 0.7409 & 0.0031 & 2.0476 & 0.0016 & 0.7875 & $1980-2005$ & 26 \\
\hline 3402000 & 0.406 & $<.0001$ & 0.3418 & 1.5432 & 0.0075 & $<.0001$ & $1942-2005$ & 64 \\
\hline 3402000 & -0.129 & 0.4412 & 0.0675 & 1.7435 & -0.0102 & 0.2829 & $1942-1960$ & 19 \\
\hline 3402000 & 0.239 & 0.0688 & 0.0770 & 1.4957 & 0.0070 & 0.1451 & $1942-1970$ & 29 \\
\hline 3402000 & 0.416 & 0.0002 & 0.2805 & 1.4605 & 0.0104 & 0.0005 & $1942-1980$ & 39 \\
\hline 3402000 & 0.044 & 0.7119 & 0.0242 & 1.7421 & 0.0027 & 0.3722 & $1971-2005$ & 35 \\
\hline 3402000 & -0.010 & 0.9441 & 0.0168 & 1.5175 & 0.0035 & 0.5363 & $1981-2005$ & 25 \\
\hline 3403000 & 0.378 & 0.0002 & 0.3067 & 1.7225 & 0.0132 & $<.0001$ & $1940-2005$ & 47 \\
\hline 3403000 & 0.291 & 0.0127 & 0.1897 & 1.6498 & 0.0151 & 0.0079 & 1940-1975 & 36 \\
\hline 3403000 & 0.200 & 0.1084 & 0.1068 & 1.6342 & 0.0126 & 0.0679 & $1940-1971$ & 32 \\
\hline 3403000 & 0.309 & 0.1857 & 0.0755 & 1.9736 & 0.0181 & 0.4134 & $1981-2005$ & 11 \\
\hline 3403500 & 0.391 & $<.0001$ & 0.2994 & 1.6387 & 0.0094 & $<.0001$ & $1924-2005$ & 62 \\
\hline 3403500 & 0.344 & 0.0023 & 0.1526 & 1.6333 & 0.0094 & 0.0153 & 1924-1978 & 38 \\
\hline 3403500 & 0.168 & 0.1849 & 0.0444 & 1.7388 & 0.0054 & 0.2551 & 1924-1971 & 31 \\
\hline 3403500 & 0.040 & 0.7916 & 0.0050 & 1.6383 & 0.0020 & 0.7483 & $1980-2005$ & 23 \\
\hline 3403910 & -0.106 & 0.4198 & 0.0103 & 1.8941 & -0.0032 & 0.5999 & $1970-2004$ & 29 \\
\hline 3404000 & 0.372 & $<.0001$ & 0.3364 & 1.4615 & 0.0133 & $<.0001$ & $1952-2006$ & 55 \\
\hline 3404000 & 0.533 & $<.0001$ & 0.5072 & 1.7653 & 0.0363 & $<.0001$ & $1952-1978$ & 27 \\
\hline
\end{tabular}


Table 2-1. Trend-test screening of annual 7-day low flows for selected long-term continuous-record streamflow-gaging stations in Kentucky for various periods of record.-Continued

[p-value, probability statistically significant if less than $0.20 ; \mathrm{n}$, number of data values; $\mathrm{R}^{2}$, coefficient of determination; $<$ less than]

\begin{tabular}{|c|c|c|c|c|c|c|c|c|}
\hline \multirow{2}{*}{$\begin{array}{l}\text { Station } \\
\text { number }\end{array}$} & \multicolumn{2}{|c|}{ Trend analysis } & \multicolumn{6}{|c|}{ Regression analysis } \\
\hline & $\begin{array}{c}\text { Mann-Kendall } \\
\text { value }\end{array}$ & p-value & $\mathbf{R}^{2}$ & $\begin{array}{l}\text { Durbin-Watson } \\
\text { value }\end{array}$ & Slope & Slope p-value & Period of record & $\mathbf{n}$ \\
\hline 3404000 & 0.439 & 0.0087 & 0.4094 & 1.7129 & 0.0456 & 0.0032 & $1952-1970$ & 19 \\
\hline 3404000 & -0.009 & 0.9501 & 0.0004 & 1.9964 & 0.0007 & 0.9166 & $1980-2006$ & 27 \\
\hline 3404500 & 0.349 & $<.0001$ & 0.2115 & 1.4669 & 0.0078 & $<.0001$ & $1909-2005$ & 82 \\
\hline 3404500 & 0.190 & 0.0265 & 0.0467 & 1.4767 & 0.0045 & 0.0863 & $1909-1978$ & 64 \\
\hline 3404500 & 0.025 & 0.7828 & 0.0000 & 1.6432 & -0.0001 & 0.9781 & $1909-1970$ & 56 \\
\hline 3404500 & -0.184 & 0.0720 & 0.0923 & 1.9803 & -0.0083 & 0.0401 & $1909-1960$ & 46 \\
\hline 3404500 & 0.309 & 0.0836 & 0.2969 & 2.1223 & 0.0193 & 0.0237 & $1980-2005$ & 17 \\
\hline 3404820 & 0.140 & 0.4517 & 0.0858 & 1.6416 & 0.0821 & 0.2380 & 1975-1992 & 18 \\
\hline 3404900 & 0.069 & 0.5864 & 0.0086 & 1.8553 & 0.0054 & 0.6206 & $1975-2005$ & 31 \\
\hline 3404900 & -0.240 & 0.2149 & 0.0245 & 1.4231 & 0.0203 & 0.5481 & $1975-1989$ & 15 \\
\hline 3404900 & -0.200 & 0.2799 & 0.0397 & 1.1155 & -0.0202 & 0.4593 & $1990-2005$ & 16 \\
\hline 3405000 & 0.233 & 0.0663 & 0.2799 & 2.1422 & 0.0158 & 0.0022 & $1924-1973$ & 31 \\
\hline 3405000 & 0.180 & 0.1638 & 0.0886 & 2.3012 & 0.0090 & 0.1102 & $1944-1973$ & 30 \\
\hline 3406000 & 0.119 & 0.5091 & 0.0190 & 2.1019 & 0.0037 & 0.5974 & $1955-1971$ & 17 \\
\hline 3406500 & 0.211 & 0.0103 & 0.1015 & 1.5932 & 0.0066 & 0.0076 & $1938-2006$ & 69 \\
\hline 3406500 & 0.137 & 0.1493 & 0.0344 & 1.5461 & 0.0049 & 0.1837 & $1938-1990$ & 53 \\
\hline 3406500 & -0.276 & 0.1369 & 0.0262 & 1.8984 & -0.0123 & 0.5490 & $1991-2006$ & 16 \\
\hline 3407100 & 0.000 & 1.0000 & 0.0142 & 1.2723 & 0.0090 & 0.7430 & $1957-1966$ & 10 \\
\hline 3407300 & -0.007 & 0.9693 & 0.0060 & 1.2691 & 0.0014 & 0.7607 & $1957-1974$ & 18 \\
\hline 3407500 & 0.237 & 0.0415 & 0.1056 & 1.5611 & 0.0360 & 0.0466 & $1954-1991$ & 38 \\
\hline 3407500 & 0.297 & 0.1158 & 0.1973 & 2.0491 & 0.0935 & 0.0741 & $1954-1970$ & 17 \\
\hline 3407500 & 0.529 & 0.0002 & 0.5170 & 2.1764 & 0.1115 & $<.0001$ & $1954-1980$ & 27 \\
\hline 3407500 & -0.216 & 0.1735 & 0.1133 & 1.8932 & -0.0651 & 0.1358 & $1971-1991$ & 21 \\
\hline 3407500 & -0.075 & 0.7528 & 0.0000 & 1.5536 & -0.0019 & 0.9888 & 1981-1991 & 11 \\
\hline 3410500 & 0.176 & 0.0437 & 0.0768 & 1.7602 & 0.0045 & 0.0292 & $1944-2005$ & 62 \\
\hline 3410500 & 0.392 & 0.0006 & 0.3077 & 1.6106 & 0.0142 & 0.0004 & 1944-1980 & 37 \\
\hline 3410500 & 0.013 & 0.9256 & 0.0031 & 2.0039 & 0.0024 & 0.7911 & $1981-2005$ & 25 \\
\hline 3410500 & 0.085 & 0.2386 & 0.0259 & 1.6258 & 0.0018 & 0.1339 & $1916-2005$ & 88 \\
\hline 3411000 & -0.311 & 0.0111 & 0.2162 & 2.0201 & -0.0127 & 0.0064 & $1916-1950$ & 33 \\
\hline 3411500 & -0.328 & 0.0056 & 0.1560 & 2.0124 & -0.0109 & 0.0189 & $1916-1950$ & 35 \\
\hline
\end{tabular}


Table 2-1. Trend-test screening of annual 7-day low flows for selected long-term continuous-record streamflow-gaging stations in Kentucky for various periods of record.-Continued

[p-value, probability statistically significant if less than $0.20 ; \mathrm{n}$, number of data values; $\mathrm{R}^{2}$, coefficient of determination; $<$ less than]

\begin{tabular}{|c|c|c|c|c|c|c|c|c|}
\hline \multirow{2}{*}{$\begin{array}{l}\text { Station } \\
\text { number }\end{array}$} & \multicolumn{2}{|c|}{ Trend analysis } & \multicolumn{6}{|c|}{ Regression analysis } \\
\hline & $\begin{array}{c}\text { Mann-Kendall } \\
\text { value }\end{array}$ & p-value & $\mathbf{R}^{2}$ & $\begin{array}{l}\text { Durbin-Watson } \\
\text { value }\end{array}$ & Slope & Slope p-value & Period of record & n \\
\hline 3412500 & 0.138 & 0.4257 & 0.0012 & 2.5922 & 0.0042 & 0.8906 & $1955-1972$ & 18 \\
\hline 3413200 & -0.067 & 0.6048 & 0.0000 & 2.1473 & -0.0001 & 0.9813 & $1970-2006$ & 30 \\
\hline 3413200 & 0.018 & 0.9163 & 0.0005 & 2.4379 & 0.0005 & 0.9278 & 1970-1995 & 19 \\
\hline 3413200 & 0.091 & 0.6971 & 0.0199 & 1.9400 & 0.0118 & 0.6789 & $1996-2006$ & 11 \\
\hline 3414000 & 0.478 & $<.0001$ & 0.2102 & 1.3322 & 0.0331 & 0.0006 & 1941-1992 & 52 \\
\hline 3414000 & 0.067 & 0.7884 & 0.0031 & 2.2960 & 0.0053 & 0.8792 & $1941-1950$ & 10 \\
\hline 3414000 & 0.282 & 0.1795 & 0.2069 & 2.4683 & 0.0294 & 0.1184 & 1980-1992 & 13 \\
\hline 3435140 & -0.174 & 0.3585 & 0.0358 & 2.7588 & -0.0345 & 0.4670 & $1975-1991$ & 17 \\
\hline 3437500 & 0.012 & 0.9368 & 0.0121 & 1.2203 & -0.0050 & 0.6167 & $1951-1973$ & 23 \\
\hline 3438000 & 0.352 & $<.0001$ & 0.2112 & 1.3985 & 0.0049 & 0.0001 & $1941-2006$ & 66 \\
\hline 3438000 & 0.399 & 0.0095 & 0.1810 & 1.1750 & 0.0153 & 0.0484 & 1941-1962 & 22 \\
\hline 3438000 & 0.186 & 0.0766 & 0.0701 & 1.6934 & 0.0035 & 0.0824 & $1963-2006$ & 44 \\
\hline 3438070 & -0.297 & 0.1663 & 0.1046 & 2.4805 & -0.0471 & 0.2592 & $1970-1983$ & 14 \\
\hline 3438220 & 0.525 & $<.0001$ & 0.5527 & 1.0407 & 0.0155 & $<.0001$ & 1941-1997 & 57 \\
\hline 3438220 & -0.057 & 0.6556 & 0.0051 & 2.0809 & -0.0015 & 0.7068 & $1968-1997$ & 30 \\
\hline 3609500 & 0.417 & $<.0001$ & 0.1900 & 1.5430 & 0.0037 & $<.0001$ & 1891-1984 & 94 \\
\hline 3609500 & 0.044 & 0.8048 & 0.0902 & 1.3606 & 0.0106 & 0.2416 & 1968-1984 & 17 \\
\hline 3610000 & -0.072 & 0.7150 & 0.0074 & 2.1271 & -0.0083 & 0.7261 & $1953-1971$ & 19 \\
\hline 3610200 & 0.565 & 0.0002 & 0.4570 & 1.9336 & 0.0252 & 0.0004 & $1984-2006$ & 23 \\
\hline 3610500 & 0.407 & 0.0007 & 0.2723 & 1.4785 & 0.0138 & 0.0015 & $1940-1973$ & 34 \\
\hline 3610500 & 0.243 & 0.1234 & 0.1145 & 1.4412 & 0.0135 & 0.1335 & $1940-1960$ & 21 \\
\hline 3610500 & 0.336 & 0.0080 & 0.1605 & 1.5067 & 0.0107 & 0.0255 & $1940-1970$ & 31 \\
\hline 3610545 & 0.228 & 0.1724 & 0.0802 & 2.1863 & 0.0078 & 0.2402 & 1970-1994 & 19 \\
\hline 3611260 & 0.355 & 0.0033 & 0.2257 & 1.3927 & 0.0111 & 0.0045 & $1973-2006$ & 34 \\
\hline 3611260 & 0.279 & 0.0793 & 0.1470 & 1.9789 & 0.0134 & 0.0862 & $1973-1993$ & 21 \\
\hline 3611260 & -0.301 & 0.1577 & 0.4004 & 1.2439 & -0.0302 & 0.0203 & 1994-2006 & 13 \\
\hline 3611500 & 0.419 & $<.0001$ & 0.3447 & 1.7407 & 0.0046 & $<.0001$ & $1929-2006$ & 78 \\
\hline 3611500 & -0.012 & 0.9167 & 0.0002 & 2.2960 & 0.0002 & 0.9303 & $1970-2006$ & 37 \\
\hline 3611500 & 0.020 & 0.8840 & 0.0028 & 2.1831 & 0.0011 & 0.7933 & $1980-2006$ & 27 \\
\hline 3611800 & 0.000 & 1.0000 & 0.1370 & 2.9221 & -0.0281 & 0.2362 & $1995-2006$ & 12 \\
\hline
\end{tabular}


Table 2-1. Trend-test screening of annual 7-day low flows for selected long-term continuous-record streamflow-gaging stations in Kentucky for various periods of record.-Continued

[p-value, probability statistically significant if less than 0.20 ; $\mathrm{n}$, number of data values; $\mathrm{R}^{2}$, coefficient of determination; $<$ less than]

\begin{tabular}{|c|c|c|c|c|c|c|c|c|}
\hline \multirow{2}{*}{$\begin{array}{l}\text { Station } \\
\text { number }\end{array}$} & \multicolumn{2}{|c|}{ Trend analysis } & \multicolumn{6}{|c|}{ Regression analysis } \\
\hline & $\begin{array}{l}\text { Mann-Kendall } \\
\text { value }\end{array}$ & p-value & $\mathbf{R}^{2}$ & $\begin{array}{c}\text { Durbin-Watson } \\
\text { value }\end{array}$ & Slope & Slope p-value & Period of record & $\mathbf{n}$ \\
\hline 3611850 & 0.515 & 0.0197 & 0.4357 & 1.9953 & 0.0193 & 0.0195 & $1995-2006$ & 12 \\
\hline 3611900 & -0.062 & 0.7829 & 0.0109 & 2.5027 & -0.0031 & 0.7467 & $1995-2006$ & 12 \\
\hline 7023000 & 0.672 & $<.0001$ & 0.7483 & 0.9236 & 0.0139 & $<.0001$ & $1940-1972$ & 33 \\
\hline 7023500 & 0.406 & 0.0275 & 0.2493 & 1.5523 & 0.0217 & 0.0212 & $1953-1973$ & 21 \\
\hline 7024000 & 0.721 & $<.0001$ & 0.7564 & 1.5277 & 0.0063 & $<.0001$ & $1941-2006$ & 59 \\
\hline
\end{tabular}




\section{Appendix 3. Double-Mass Curves Showing Relations of Cumulative Annual 7-Day Low Flows among Selected Hydro-Climate Data Network, Hydrologic Benchmark Network, and Reference Streamflow-Gaging Stations in and surrounding Kentucky}

Time-series plots of the annual low flows for all LTCR stations in Kentucky were examined and compared to each other and to the plots of selected LTCR stations in the HydroClimate Data Network (HCDN) (Slack and Landwehr, 1992) and Hydrologic Benchmark Network (HBN) (Mast and Turk, 1999) in Kentucky and bordering States. These stations included Twin Creek near Germantown, Ohio, (03272000); Little Wabash River below Clay City, Illinois, (03379500,); French Broad River at Ashville, North Carolina, (03451500,); Clinch River above Tazewell, Tennessee, (03528000); Tellico River at Tellico Plains, Tennessee, (03518500); Greenbrier River at Alderson, West Virginia, (03183500); Nolichucky River at Embreeville, Tennessee, (03465500); Powell River near Jonesville, Virginia, (03531500) in (or subbasins of) the HCDN and Holiday Creek near Andersonville, Virginia, (02038850); Upper Twin Creek at McGaw, Ohio, (03237280); Cataloochee Creek near Cataloochee, North Carolina, (03460000); Little River above Townsend, Tennessee, (03497300); North Sylamore Creek near Fifty Six, Arkansas, (07060710) in (or subbasins of) the HBN.

The annual low-flow data for South Fork Cumberland River near Stearns, Kentucky, (03410500) was identified as representative of basins in Kentucky largely unaffected by regulation and (or) direct anthropogenic alterations such that low flows varied only in response to climate and meteorological conditions and were suitable for low-flow frequency analysis. Double-mass curves (Searcy and others, 1960) showing relations of the cumulative annual 7-day low flows for these HCDN and HBN stations paired with the record at the Stearns, Kentucky, gage as the reference (abscissa) (figs. 3-1 and 3-2) were plotted to compare the record at Stearns with low flows at long-term benchmark stations in the region.

Many, but not all, of the HCDN and HBN stations have a low-flow regime unaffected by regulation and (or) local diversions of flows that results in a double-mass curve of uniform linear slope indicative of no change in the relation between the paired time series. A change or break in the slope of the double-mass curve signals that the relation between the time series has changed for some reason. The most common cause is a basin modification such as regulation or local diversions - water withdrawals and discharges - that have changed the low-flow regime in one of the basins. Any anthropogenic alterations of the low flows at gages in Kentucky tended to be more common in the later part of the streamflow record - after 1980, for example.
A distinct change in slope of the double-mass curves plotted for these HCDN and HBN stations with the Stearns, Kentucky, gage as the reference station was observed, however, at several but not all stations around the year 1960 and occasionally in the early 1970 s (figs. 3-1 and 3-2). Typically these double-mass curves had a uniform linear slope before and after such a change in slope around 1960 and 1970. This change in slope around 1960 also was observed when plotting other selected HCDN and HBN stations surrounding Kentucky against each other (fig. 3-3), which indicates a likely regional phenomenon not unique to the selected reference gage at Stearns, Kentucky. The double-mass curves for stations at latitudes near Kentucky show this change in slope around 1960, while the double-mass curves for stations farther south of Kentucky exhibited the change in slope at a later date around 1970. A double-mass curve comparing a station near Kentucky to one farther south of Kentucky (fig. 3-3 C) also possibly indicated slope changes around both 1960 and 1970.

These changes in slope of the double-mass curves are possibly related to shifts in the hydroclimate regime characterized by a transition from around 1960 into the early 1970s from a warm-dry period to a cool-wet period as identified by other researchers (Lins and Slack, 1999; Enfield and others, 2001; Grundstein and Bentley, 2001; McCabe and Wolock, 2002; and McCabe and others, 2004). Identification of the exact nature and causes of a possible shift in the regional hydroclimate regime was beyond the scope of this study.

Seventy-four stations in Kentucky had streamflow timeseries records that span the climate years 1959-60, of which 6 stations were identified as having the approximately 1960 change in slope of the double-mass curve that was used as the end point of the identified homogeneous period of record for low-flow frequency analysis (table 2 in main report). Therefore, for the large majority stations (about 90 percent), no change in slope of the double-mass curves plotted with the Stearns reference station around 1960 was identified. Some of these 6 stations with identified homogeneous periods ending in 1959 or 1960 may have been truncated prematurely as a result of this change in slope around 1960. However, a homogeneous, representative period of record of at least 10 years was identified nonetheless and used in the low-flow frequency analysis for these six stations. Use of the Stearns, Kentucky, low-flow record as the reference station in screening and identifying the homogeneous periods of record at all the LTCR stations in Kentucky was considered appropriate. 
A. Greenbrier River at Alderson, West Virginia (03183500),

concurrent-flow period 1916-31, 1934-2005; 1,364 mi²

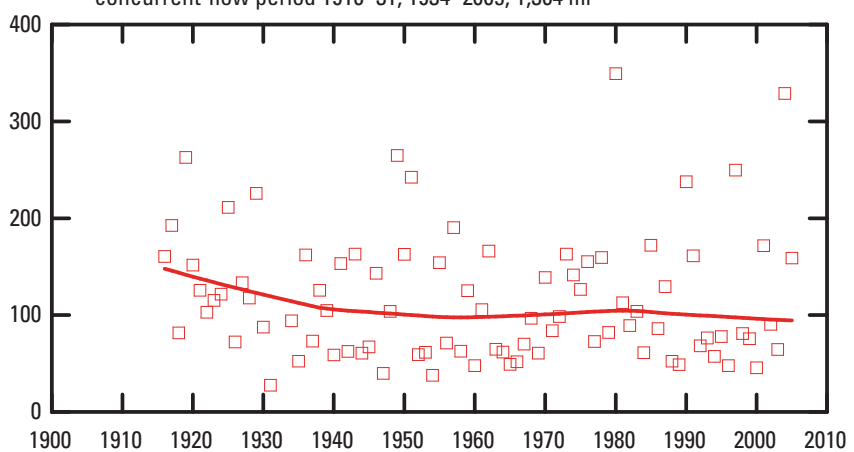

B. Twin Creek near Germantown, Ohio (03272000),

concurrent-flow period 1916-23, 1928-2005; $275 \mathrm{mi}^{2}$

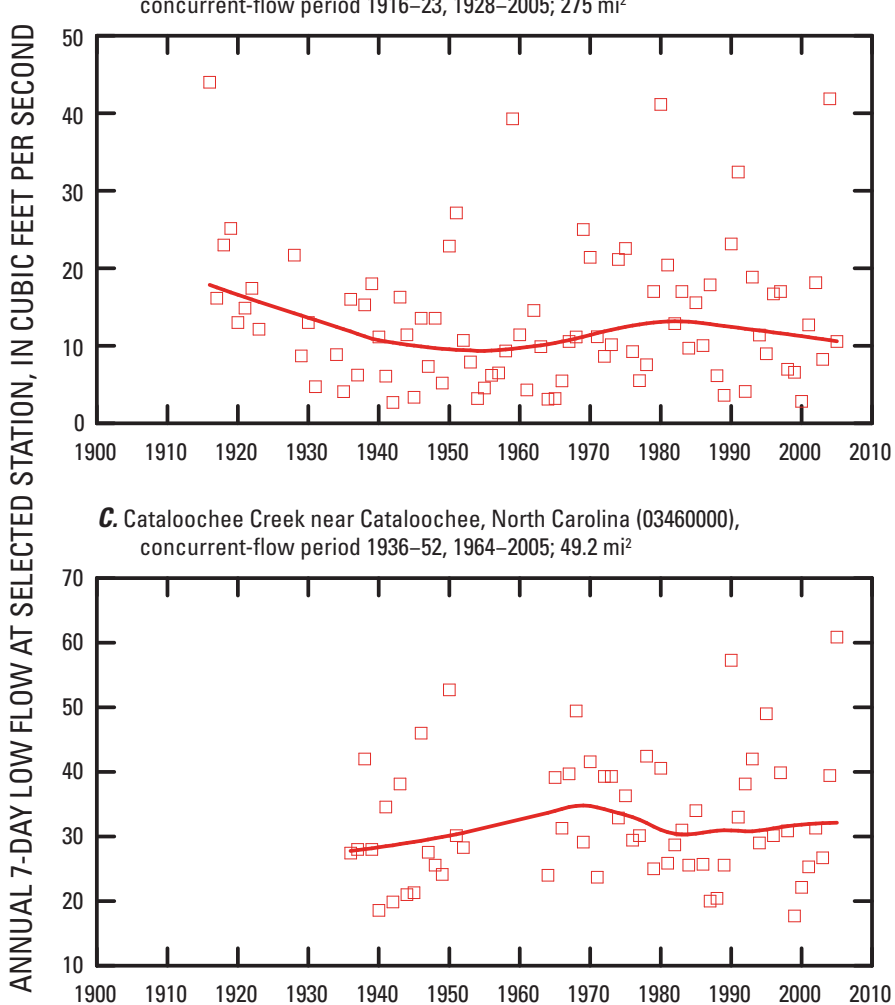

D. Clinch River above Tazewell, Tennessee (03528000) concurrent-flow period 1920-31, 1934-2005; 1,474 mi²

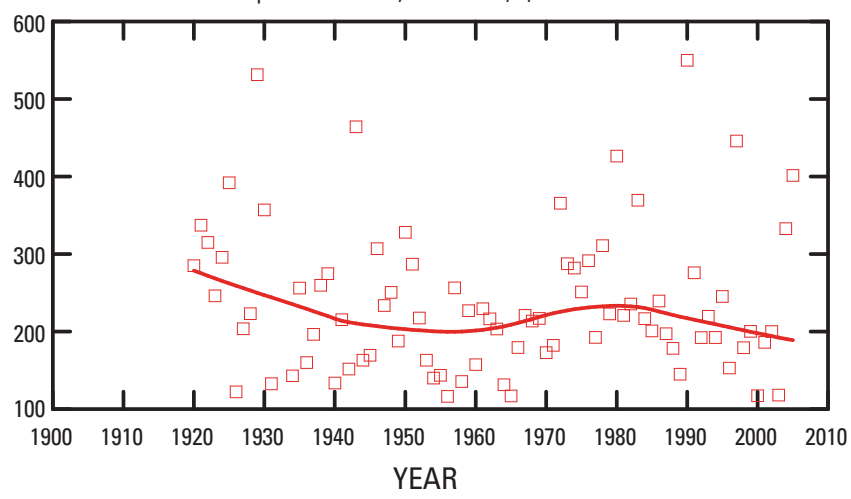

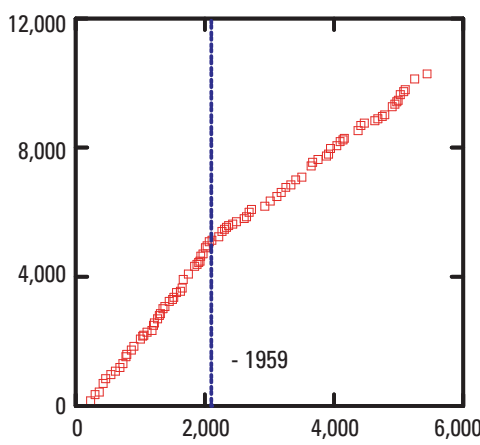

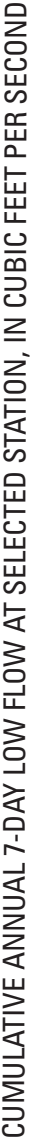
15,0
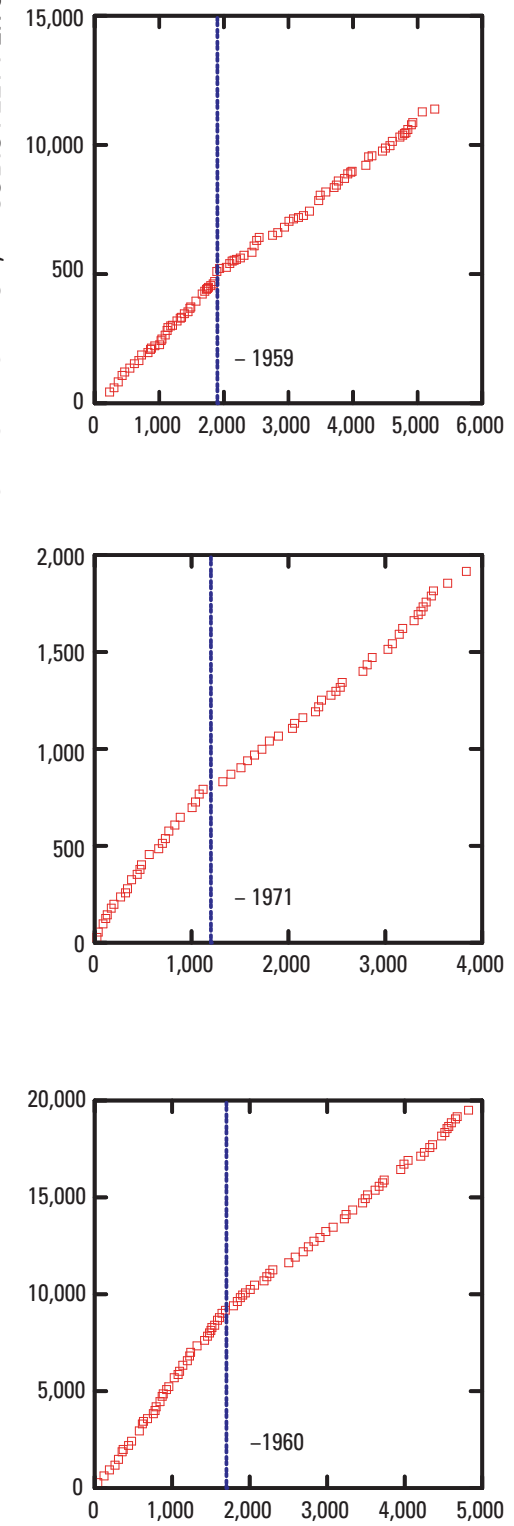

CUMULATIVE ANNUAL 7-DAY LOW FLOW AT REFERENCE STATION, IN CUBIC FEET PER SECOND

Figure 3-1. Annual 7-day low-flow time series with LOWESS curve and double-mass plots versus reference station South Fork Cumberland River near Stearns, Kentucky (03410500), for $\boldsymbol{A}$, Greenbrier River at Alderson, West Virginia; B, Twin Creek near Germantown, Ohio; $\boldsymbol{C}$, Cataloochee Creek near Cataloochee, North Carolina; and $\boldsymbol{D}$, Clinch River above Tazewell, Tennessee. 
A. Tellico River at Tellico Plains, Tennessee (03518500), concurrent-flow period 1927-31, 1934-81; $118 \mathrm{mi}^{2}$
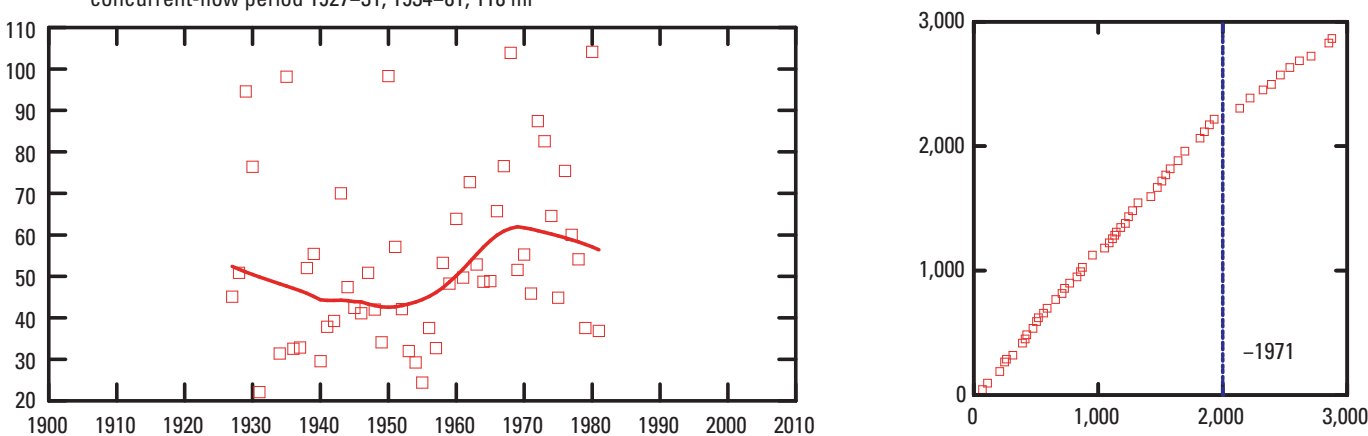

B. Little Wabash River below Clay City, Illinois (03379500), concurrent-flow period 1916-31, 1934-2005; 1,131 mi²

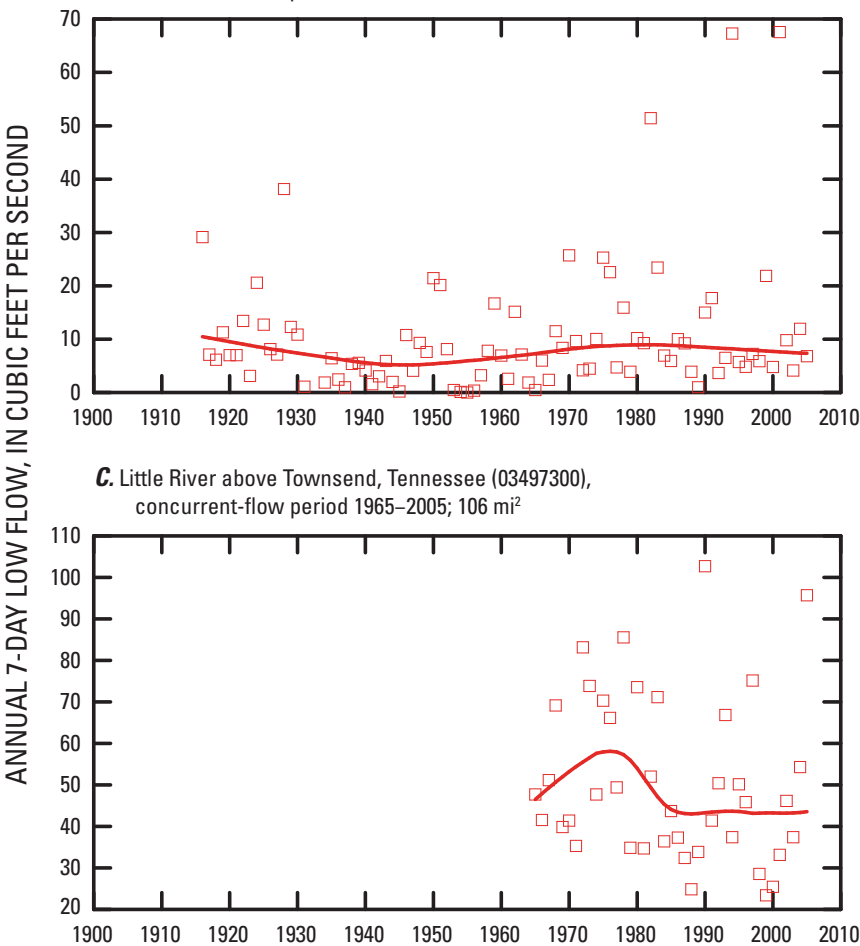

D. North Sylamore Creek near Fifty-Six, Arkansas (07060710), concurrent-flow period 1967-2005; $58.1 \mathrm{mi}^{2}$
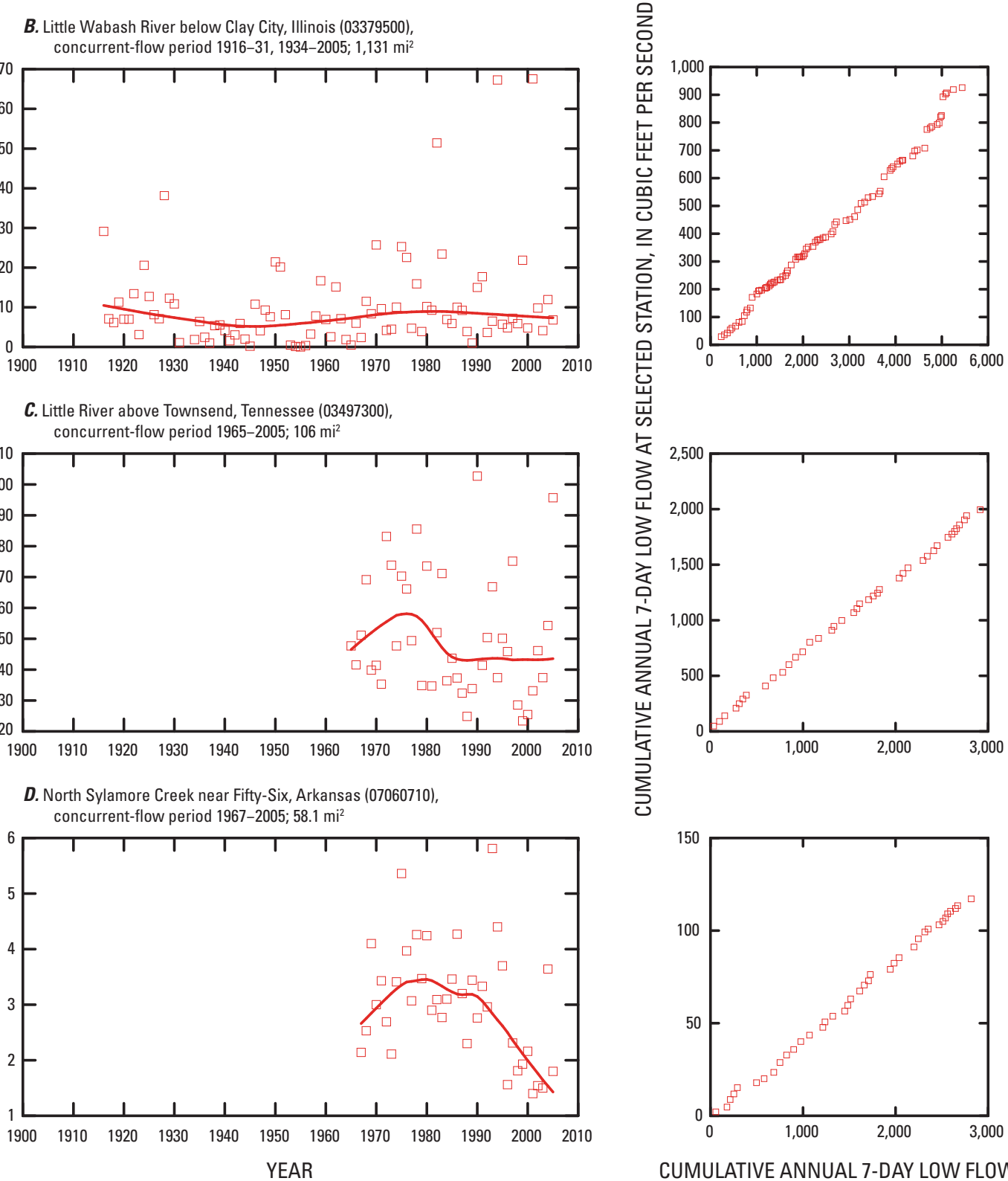

CUMULATIVE ANNUAL 7-DAY LOW FLOW AT REFERENCE STATION, IN CUBIC FEET PER SECOND

Figure 3-2. Annual 7-day low-flow time series with LOWESS curve and double-mass plots versus reference station South Fork Cumberland River near Stearns, Kentucky (03410500), for $\boldsymbol{A}$, Tellico River at Tellico Plains, Tennessee; $\boldsymbol{B}$, Little Wabash River below Clay City, Illinois (03379500); $\boldsymbol{C}$, Little River above Townsend, Tennessee; and $\boldsymbol{D}$, North Sylamore Creek near Fifty-Six, Arkansas. 
A. Twin Creek near Germantown, Ohio (03272000) (ordinate), versus Greenbrier River at Alderson, West Virginia (03183500)(abscissa),

for 1916-2007 concurrent-flow period

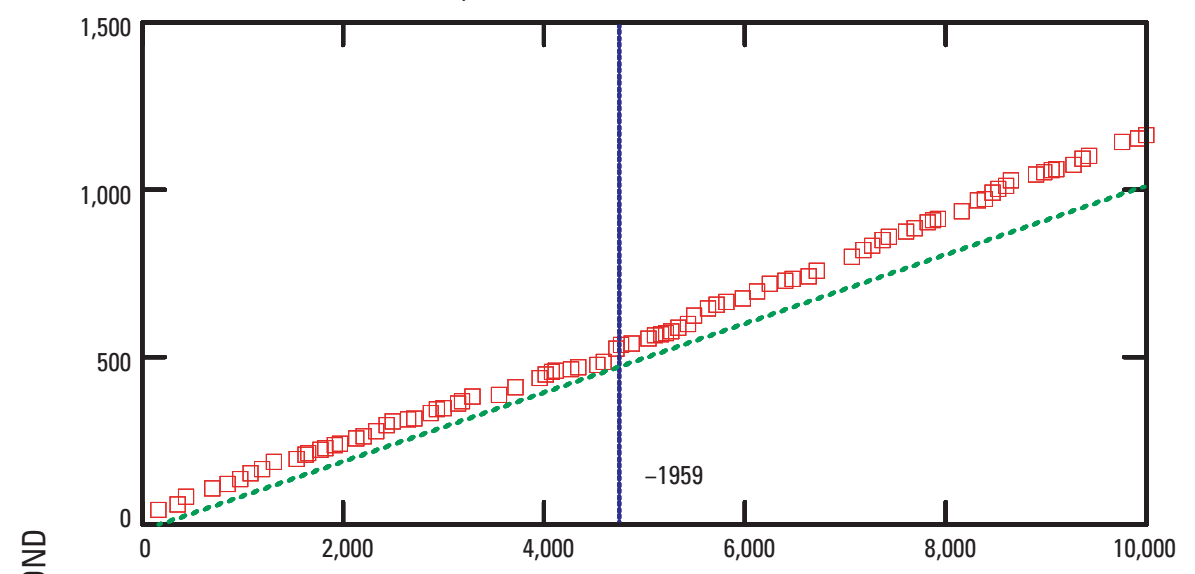

B. Powell River near Jonesville, Virginia (03531500) versus

Clinch River above Tazewell, Tennessee (03528000)

for 1933-99 concurrent-flow period

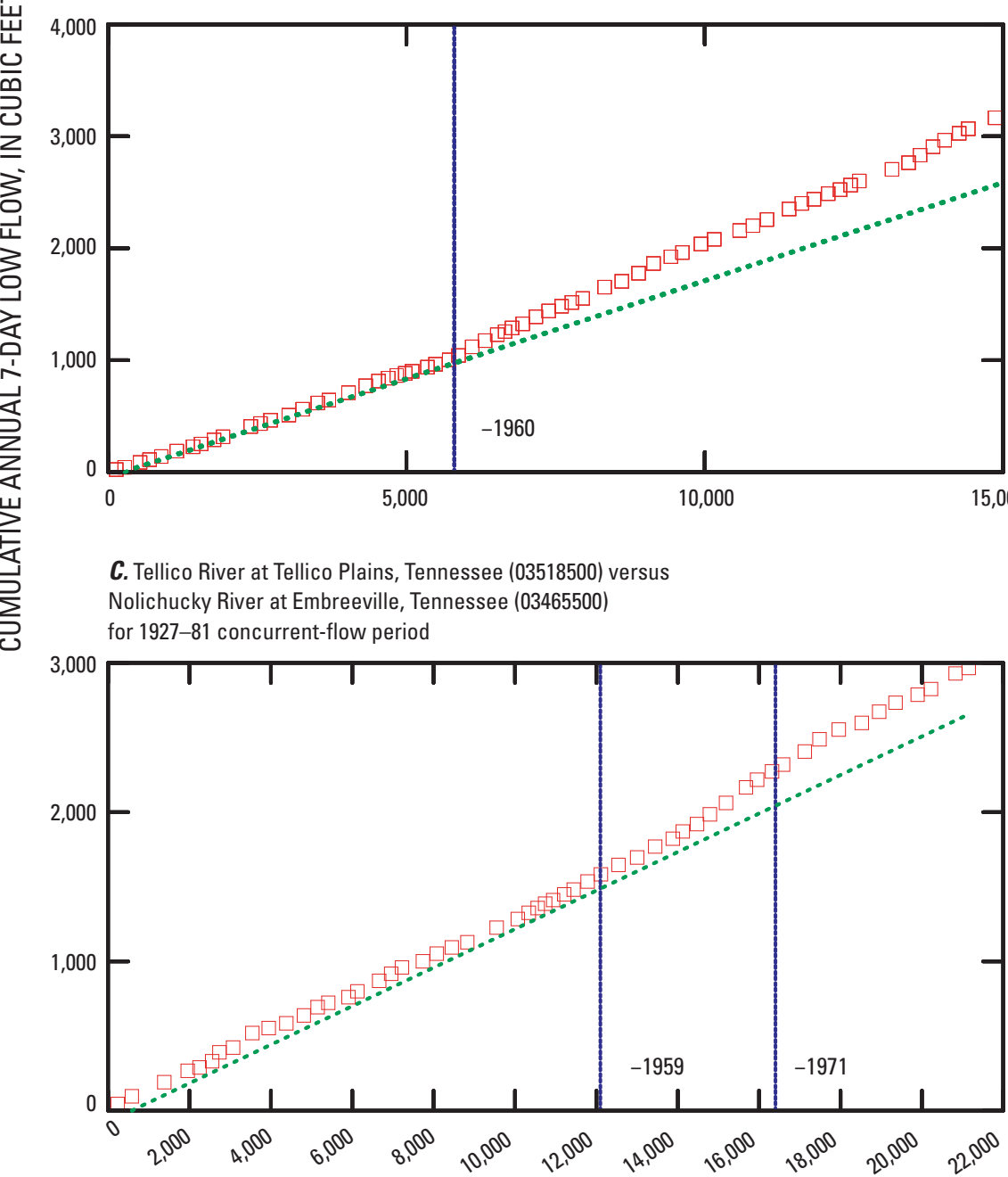

CUMULATIVE ANNUAL 7-DAY LOW FLOW, IN CUBIC FEET PER SECOND

Figure 3-3. Double-mass plots of cumulative annual 7-day low flows for $\boldsymbol{A}$, Twin Creek near Germantown, Ohio, versus Greenbrier River at Alderson, West Virginia; $\boldsymbol{B}$, Powell River near Jonesville, Virginia, versus Clinch River above Tazewell, Tennessee; and $\boldsymbol{C}$, Tellico River at Tellico Plains, Tennessee, versus Nolichucky River at Embreeville, Tennessee. 


\section{Appendix 4. A Procedure for Detrending Annual Low-Flow Data for Frequency Analysis}

Selected LTCR low-flow stations, including some previously used as low-flow index stations, had trended annual lowflow time series (table 1 in main report, fig. 4-1). These trends were most likely caused by various ongoing anthropogenic basin modifications including mining activities, agricultural irrigation and drainage systems, stream channelization, and local diversions of flows that have altered the low-flow regime during the station periods of record.

A procedure and example application for adjustments of trended annual low flows are described here. This procedure was based on procedures developed by Ries and Dillow (2006) to adjust for trends in annual peak flows based on time alone. The estimates were made by use of LOWESS, or Locally Weighted Scatterplot Smoothing (Cleveland 1979, 1984; Helsel and Hirsch, 2002), which defined smoothed trend lines for an annual flow time series. These adjustments for trend in effect shifted the annual low-flow values 'forward' in time to the most recent year of trended record and (or) the adjustments shifted the annual values 'backward' in time to the beginning of the trended period of record. These shifted low-flow characteristics were assumed representative of basin hydrologic conditions at the point in time to which the series was adjusted.

Estimates of low-flow frequency, in section "Long-term Continuous-Record Streamflow-Gaging Stations," calculated by using the Pearson Type III distribution are a function of the mean, standard deviation, and skew of the logarithms of the annual low-flow series. As the first step in this low-flow detrending procedure, the mean value of the logarithms of annual low flows was taken as the LOWESS estimate in logspace flow at the beginning and (or) ending point of trended period.

The arithmetic trend-adjusted low-flow time series values were next determined by converting the log-space LOWESS values to equivalent arithmetic values of flow by detransforming from the log base- 10 values. Residuals around the smoothed arithmetic trend line were then computed by subtracting each annual arithmetic trend-line flow value from the observed annual low-flow value. These arithmetic residuals were then shifted to a point higher or lower on the discharge (ordinate) scale to the smoothed arithmetic trend-line low flow (as determined from the log-space LOWESS curve) at the beginning and (or) ending year in the record, depending on the year and basin condition for which a low-flow frequency statistic was needed.
The trend-adjusted annual low-flow values were next log transformed prior to the subsequent steps in this detrending procedure. For estimation of standard deviation and skew of the trend-adjusted record, the 5-, 6-, 7-, 8-, 9-, and 10-year 'moving periods' of the trend-adjusted log-transformed annual-low-flow record were calculated. These series of moving-period statistics were plotted and also fitted with a LOWESS line to estimate representative values of the standard deviation and skew at the beginning and (or) ending year of the trended periods of record. The moving-period statistics and LOWESS-curve values typically followed a similar pattern in the plots and generally tended to converge toward the same proximate values at the beginning and (or) ending year of the trended periods of record.

Plots of annual 7-day low flows at station 07023000 (Mayfield Creek at Lovelaceville, Ky.) for the period 1940-72 that illustrate a trend adjustment to 1972 basin conditions are shown in fig. 3-1. The LOWESS-curve estimate for the mean of the logarithms of the annual 7-day low-flow series at station 07023000, adjusted to 1972 basin conditions, $1.325 \log \mathrm{ft}^{3} / \mathrm{s}$ units, or $21.1 \mathrm{ft}^{3} / \mathrm{s}$, is shown in fig. 4-1A. The arithmetic original, LOWESS curve, and detrended time series for 1972 basin conditions at gaging station 07023000 are shown in fig. 4-1B . Arithmetic residuals were shifted by adding to a constant LOWESS-curve value in 1972 of $21.1 \mathrm{ft}^{3} / \mathrm{s}$, which was taken as the estimated mean of the detrended series. Next, the LOWESS estimates of the standard deviation of the logarithms of annual 7-day low flows at station 07023000 adjusted to 1972 for the 6-, 8-, and 10-year moving periods are shown in fig. 4-1C . Finally, the LOWESS-curve estimates of the skew coefficient of the logarithms of annual 7-day low flows at station 07023000 adjusted to 1972 for the 6-, 8-, and 10-year moving periods are shown in fig. 4-1D. For the 10 year moving period, the standard deviation and skew LOWESS-curve estimates at 1972 are 0.061 and 0.774 , respectively. For these estimated mean, standard deviation, and skew values of the logarithms of annual 7-day low flows; the estimated $7 \mathrm{Q}_{10}$ of the trend-adjusted annual 7-day lows for 1972 basin conditions was $17.9 \mathrm{ft}^{3} / \mathrm{s}$. When this same procedure was applied to trend-adjusted annual low flows for 1940 basin conditions, the estimated $7 \mathrm{Q}_{10}$ was $5.4 \mathrm{ft}^{3} / \mathrm{s}$, about one third the estimate for 1972 basin conditions. 

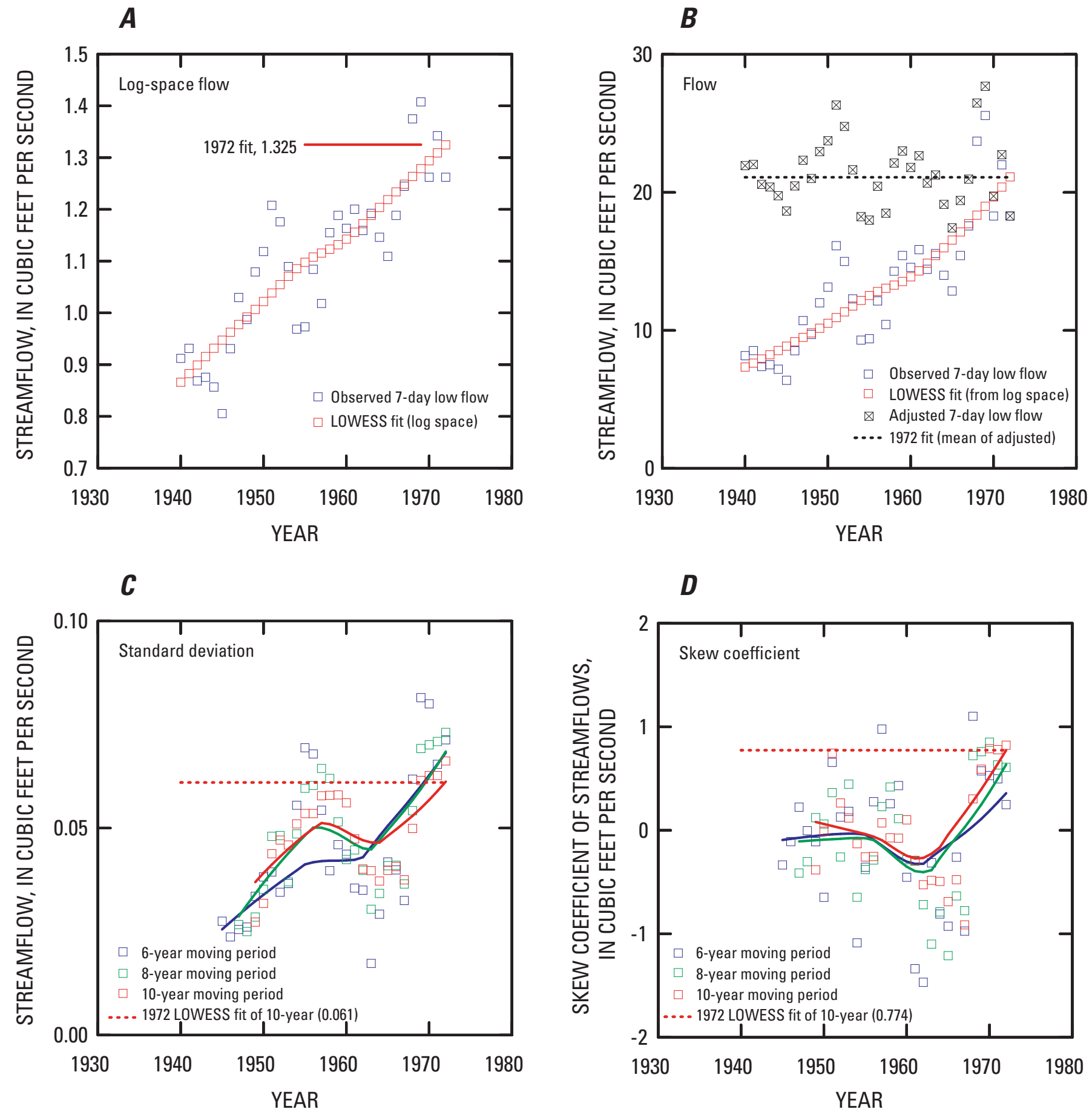

Figure 4-1. Adjustments of annual 7-day low flows and estimates of mean, standard deviation, and skew of the logarithms of annual 7-day low flows at Mayfield Creek at Lovelaceville, Kentucky (07023000) for basin conditions in 1972. 


\section{Appendix 5. Classification Tables for Logistic-Regression Equations for Estimating the Probability of Zero Flow For Selected Low-Flow Frequencies in Kentucky}

Analysis of the estimates provided by the logistic-regression estimating equations indicated optimal performance in terms of the percentage of gaging stations correctly classified as zero or nonzero flow for each low-flow statistic $\left(30 \mathrm{Q}_{2}\right.$, $30 \mathrm{Q}_{5}, 7 \mathrm{Q}_{2}, 7 \mathrm{Q}_{10}, 7 \mathrm{Q}_{20}$ ) varied depending on the particular 'cutpoint' probability used. Classification tables (SAS Institute, Inc., 1995; Hosmer and Lemeshow, 2000) (tables 5-1 through 5-5) were developed by determining the numbers of correct and incorrect classifications of events (zero flow) and nonevent (nonzero flow) by comparison of the estimated probabilities to the zero and nonzero status of each low-flow statistic at the various probability cutpoints. The optimal cutpoints are shown in bold numbers in the classification tables. The logistic-regression equations were adjusted to operate at the optimal cutpoints by multiplying the probabilities computed from the logistic regression equation by the ratio of the standard cutpoints to the optimal cutpoints. For example, the standard cutpoint for $7 \mathrm{Q}_{2}$ is 0.5 (inverse of the return period, $1 / \mathrm{T}$ or $1 / 2$ ), at which 73.2 percent of stations were classified correctly. The optimal cutpoint is 0.985 , at which 93.8 percent of the stations were classified correctly. To get optimal results at the standard cutpoint for $7 \mathrm{Q}_{2}$, a conversion factor $(\mathrm{C}$, in table 4 in main report) of 0.508 ( 0.5 divided by 0.985 ) was applied to the final logistic-regression equation.

The logistic-regression equations are applied to determine if the statistic of interest is either zero or nonzero. The estimated probabilities of zero flows are compared to the standard probability cutpoints that equal the probability of the statistics of interest (inverse of the return period, $1 / \mathrm{T}$ ). If the estimated probability of zero flow is greater than the nonexceedance probability of the low-flow statistic of interest, then the lowflow statistic is estimated to be zero. For example, in the $7 Q_{10}$ statistic, if the estimated probability of zero flow exceeds 0.1 , then the $7 \mathrm{Q}_{10}$ is estimated to be zero. Alternatively, for the $7 Q_{10}$ statistic, if the probability of zero flow is less than or equal to 0.1 , then the $7 Q_{10}$ should be estimated by using the multiple-linear-regression equations for estimating nonzero low-flow statistics (table 5 in main report).

Table 5-1. Classification table for the logistic-regression equation for estimating zero-flow probability for the 30-day, 2-year low flow in Kentucky.

[Correct, number of observations correctly classified; Incorrect, number of observations incorrectly classified; Event, zero flow; Nonevent, nonzero flow; Percentages: Correct, the frequency with which the equation correctly classifies the low-flow statistic for each probability cutpoint; Sensitivity, the ratio of correctly classified events to the total number of events; Specificity, the ratio of correctly classified nonevents to the total number of nonevents; False positive, the ratio of the number of nonevents incorrectly classified as events to the sum of all observations classified as events; False negative, the ratio of the number of events incorrectly classified as nonevents to the sum of all observations classified as nonevents; SAS Institute, Inc., 1995, p. 45-50]

\begin{tabular}{|c|c|c|c|c|c|c|c|c|c|}
\hline \multirow{2}{*}{$\begin{array}{c}\text { Probability } \\
\text { level } \\
\text { (cutpoint) }\end{array}$} & \multicolumn{2}{|c|}{ Correct } & \multicolumn{2}{|c|}{ Incorrect } & \multicolumn{5}{|c|}{ Percentages } \\
\hline & Event & Nonevent & Event & Nonevent & Correct & Sensitivity & Specificity & $\begin{array}{c}\text { False } \\
\text { positive }\end{array}$ & $\begin{array}{c}\text { False } \\
\text { negative }\end{array}$ \\
\hline 0.05 & 8 & 31 & 73 & 0 & 34.8 & 100.0 & 29.8 & 90.1 & 0.0 \\
\hline .1 & 8 & 42 & 62 & 0 & 44.6 & 100.0 & 40.4 & 88.6 & .0 \\
\hline .2 & 8 & 53 & 51 & 0 & 54.5 & 100.0 & 51.0 & 86.4 & .0 \\
\hline .3 & 8 & 59 & 45 & 0 & 59.8 & 100.0 & 56.7 & 84.9 & .0 \\
\hline .4 & 8 & 65 & 39 & 0 & 65.2 & 100.0 & 62.5 & 83.0 & .0 \\
\hline .5 & 8 & 71 & 33 & 0 & 70.5 & 100.0 & 68.3 & 80.5 & .0 \\
\hline .6 & 8 & 74 & 30 & 0 & 73.2 & 100.0 & 71.2 & 78.9 & .0 \\
\hline .7 & 8 & 78 & 26 & 0 & 76.8 & 100.0 & 75.0 & 76.5 & .0 \\
\hline .8 & 8 & 82 & 22 & 0 & 80.4 & 100.0 & 78.8 & 73.3 & .0 \\
\hline .9 & 8 & 87 & 17 & 0 & 84.8 & 100.0 & 83.7 & 68.0 & .0 \\
\hline .985 & 7 & 102 & 2 & 1 & 97.3 & 87.5 & 98.1 & 22.2 & 1.0 \\
\hline .99 & 7 & 103 & 1 & 1 & 98.2 & 87.5 & 99.0 & 12.5 & 1.0 \\
\hline .995 & 5 & 104 & 0 & 3 & 97.3 & 62.5 & 100.0 & .0 & 2.8 \\
\hline
\end{tabular}




\section{Methods for Estimating Selected Low-Flow Frequency Statistics for Unregulated Streams in Kentucky}

Table 5-2. Classification table for the logistic-regression equation for estimating zero-flow probability for the 30-day, 5-year low flow in Kentucky.

[Correct, number of observations correctly classified; Incorrect, number of observations incorrectly classified; Event, zero flow; Nonevent, nonzero flow; Percentages: Correct, the frequency with which the equation correctly classifies the low-flow statistic for each probability cutpoint; Sensitivity, the ratio of correctly classified events to the total number of events; Specificity, the ratio of correctly classified nonevents to the total number of nonevents; False positive, the ratio of the number of nonevents incorrectly classified as events to the sum of all observations classified as events; False negative, the ratio of the number of events incorrectly classified as nonevents to the sum of all observations classified as nonevents; SAS Institute, Inc., 1995, p. 45-50]

\begin{tabular}{|c|c|c|c|c|c|c|c|c|c|}
\hline \multirow{2}{*}{$\begin{array}{c}\text { Probability } \\
\text { level } \\
\text { (cutpoint) }\end{array}$} & \multicolumn{2}{|c|}{ Correct } & \multicolumn{2}{|c|}{ Incorrect } & \multicolumn{5}{|c|}{ Percentages } \\
\hline & Event & Nonevent & Event & Nonevent & Correct & Sensitivity & Specificity & $\begin{array}{c}\text { False } \\
\text { positive }\end{array}$ & $\begin{array}{c}\text { False } \\
\text { negative }\end{array}$ \\
\hline 0.05 & 29 & 31 & 52 & 0 & 53.6 & 100.0 & 37.3 & 64.2 & 0.0 \\
\hline .1 & 29 & 42 & 41 & 0 & 63.4 & 100.0 & 50.6 & 58.6 & .0 \\
\hline .2 & 28 & 52 & 31 & 1 & 71.4 & 96.6 & 62.7 & 52.5 & 1.9 \\
\hline .3 & 28 & 58 & 25 & 1 & 76.8 & 96.6 & 69.9 & 47.2 & 1.7 \\
\hline .4 & 28 & 64 & 19 & 1 & 82.1 & 96.6 & 77.1 & 40.4 & 1.5 \\
\hline .5 & 27 & 69 & 14 & 2 & 85.7 & 93.1 & 83.1 & 34.1 & 2.8 \\
\hline .6 & 27 & 72 & 11 & 2 & 88.4 & 93.1 & 86.7 & 28.9 & 2.7 \\
\hline .7 & 27 & 76 & 7 & 2 & 92.0 & 93.1 & 91.6 & 20.6 & 2.6 \\
\hline .75 & 26 & 78 & 5 & 3 & 92.9 & 89.7 & 94.0 & 16.1 & 3.7 \\
\hline .8 & 26 & 79 & 4 & 3 & 93.8 & 89.7 & 95.2 & 13.3 & 3.7 \\
\hline .825 & 25 & 80 & 3 & 4 & 93.8 & 86.2 & 96.4 & 10.7 & 4.8 \\
\hline .85 & 25 & 80 & 3 & 4 & 93.8 & 86.2 & 96.4 & 10.7 & 4.8 \\
\hline .9 & 23 & 81 & 2 & 6 & 92.9 & 79.3 & 97.6 & 8.0 & 6.9 \\
\hline .95 & 22 & 82 & 1 & 7 & 92.9 & 75.9 & 98.8 & 4.3 & 7.9 \\
\hline .99 & 8 & 83 & 0 & 21 & 81.3 & 27.6 & 100.0 & .0 & 20.2 \\
\hline
\end{tabular}


Table 5-3. Classification table for the logistic-regression equation for estimating zero-flow probability for the 7-day, 2-year low flow in Kentucky.

[Correct, number of observations correctly classified; Incorrect, number of observations incorrectly classified; Event, zero flow; Nonevent, nonzero flow; Percentages: Correct, the frequency with which the equation correctly classifies the low-flow statistic for each probability cutpoint; Sensitivity, the ratio of correctly classified events to the total number of events; Specificity, the ratio of correctly classified nonevents to the total number of nonevents; False positive, the ratio of the number of nonevents incorrectly classified as events to the sum of all observations classified as events; False negative, the ratio of the number of events incorrectly classified as nonevents to the sum of all observations classified as nonevents; SAS Institute, Inc., 1995, p. 45-50]

\begin{tabular}{|c|c|c|c|c|c|c|c|c|c|}
\hline \multirow{2}{*}{$\begin{array}{c}\text { Probability } \\
\text { level } \\
\text { (cutpoint) }\end{array}$} & \multicolumn{2}{|c|}{ Correct } & \multicolumn{2}{|c|}{ Incorrect } & \multicolumn{5}{|c|}{ Percentages } \\
\hline & Event & Nonevent & Event & Nonevent & Correct & Sensitivity & Specificity & $\begin{array}{c}\text { False } \\
\text { positive }\end{array}$ & $\begin{array}{c}\text { False } \\
\text { negative }\end{array}$ \\
\hline 0.05 & 27 & 23 & 62 & 0 & 44.6 & 100.0 & 27.1 & 69.7 & 0.0 \\
\hline .1 & 27 & 31 & 54 & 0 & 51.8 & 100.0 & 36.5 & 66.7 & .0 \\
\hline .2 & 27 & 39 & 46 & 0 & 58.9 & 100.0 & 45.9 & 63.0 & .0 \\
\hline .3 & 26 & 48 & 37 & 1 & 66.1 & 96.3 & 56.5 & 58.7 & 2.0 \\
\hline .4 & 26 & 50 & 35 & 1 & 67.9 & 96.3 & 58.8 & 57.4 & 2.0 \\
\hline .5 & 26 & 56 & 29 & 1 & 73.2 & 96.3 & 65.9 & 52.7 & 1.8 \\
\hline .6 & 26 & 58 & 27 & 1 & 75.0 & 96.3 & 68.2 & 50.9 & 1.7 \\
\hline .7 & 26 & 63 & 22 & 1 & 79.5 & 96.3 & 74.1 & 45.8 & 1.6 \\
\hline .8 & 26 & 67 & 18 & 1 & 83.0 & 96.3 & 78.8 & 40.9 & 1.5 \\
\hline .9 & 25 & 74 & 11 & 2 & 88.4 & 92.6 & 87.1 & 30.6 & 2.6 \\
\hline .98 & 23 & 80 & 5 & 4 & 92.0 & 85.2 & 94.1 & 17.9 & 4.8 \\
\hline .985 & 23 & 82 & 3 & 4 & 93.8 & 85.2 & 96.5 & 11.5 & 4.7 \\
\hline .99 & 22 & 83 & 2 & 5 & 93.8 & 81.5 & 97.6 & 8.3 & 5.7 \\
\hline .995 & 19 & 84 & 1 & 8 & 92.0 & 70.4 & 98.8 & 5.0 & 8.7 \\
\hline .999 & 8 & 85 & 0 & 19 & 83.0 & 29.6 & 100.0 & .0 & 18.3 \\
\hline
\end{tabular}




\section{Methods for Estimating Selected Low-Flow Frequency Statistics for Unregulated Streams in Kentucky}

Table 5-4. Classification table for the logistic-regression equation for estimating zero-flow probability for the 7-day, 10-year low flow in Kentucky.

[Correct, number of observations correctly classified; Incorrect, number of observations incorrectly classified; Event, zero flow; Nonevent, nonzero flow; Percentages: Correct, the frequency with which the equation correctly classifies the low-flow statistic for each probability cutpoint; Sensitivity, the ratio of correctly classified events to the total number of events; Specificity, the ratio of correctly classified nonevents to the total number of nonevents; False positive, the ratio of the number of nonevents incorrectly classified as events to the sum of all observations classified as events; False negative, the ratio of the number of events incorrectly classified as nonevents to the sum of all observations classified as nonevents; SAS Institute, Inc., 1995, p. 45-50]

\begin{tabular}{|c|c|c|c|c|c|c|c|c|c|}
\hline \multirow{2}{*}{$\begin{array}{c}\text { Probability } \\
\text { level } \\
\text { (cutpoint) }\end{array}$} & \multicolumn{2}{|c|}{ Correct } & \multicolumn{2}{|c|}{ Incorrect } & \multicolumn{5}{|c|}{ Percentages } \\
\hline & Event & Nonevent & Event & Nonevent & Correct & Sensitivity & Specificity & $\begin{array}{c}\text { False } \\
\text { positive }\end{array}$ & $\begin{array}{c}\text { False } \\
\text { negative }\end{array}$ \\
\hline 0.05 & 52 & 23 & 37 & 0 & 67.0 & 100.0 & 38.3 & 41.6 & 0.0 \\
\hline .1 & 52 & 31 & 29 & 0 & 74.1 & 100.0 & 51.7 & 35.8 & .0 \\
\hline .2 & 50 & 37 & 23 & 2 & 77.7 & 96.2 & 61.7 & 31.5 & 5.1 \\
\hline .3 & 49 & 46 & 14 & 3 & 84.8 & 94.2 & 76.7 & 22.2 & 6.1 \\
\hline .4 & 48 & 47 & 13 & 4 & 84.8 & 92.3 & 78.3 & 21.3 & 7.8 \\
\hline .5 & 46 & 51 & 9 & 6 & 86.6 & 88.5 & 85.0 & 16.4 & 10.5 \\
\hline .55 & 46 & 52 & 8 & 6 & 87.5 & 88.5 & 86.7 & 14.8 & 10.3 \\
\hline .6 & 45 & 52 & 8 & 7 & 86.6 & 86.5 & 86.7 & 15.1 & 11.9 \\
\hline .7 & 42 & 54 & 6 & 10 & 85.7 & 80.8 & 90.0 & 12.5 & 15.6 \\
\hline .8 & 40 & 56 & 4 & 12 & 85.7 & 76.9 & 93.3 & 9.1 & 17.6 \\
\hline .9 & 34 & 58 & 2 & 18 & 82.1 & 65.4 & 96.7 & 5.6 & 23.7 \\
\hline .99 & 24 & 60 & 0 & 28 & 75.0 & 46.2 & 100.0 & .0 & 31.8 \\
\hline
\end{tabular}


Table 5-5. Classification table for the logistic-regression equation for estimating zero-flow probability for the 7-day, 20-year low flow in Kentucky.

[Correct, number of observations correctly classified; Incorrect, number of observations incorrectly classified; Event, zero flow; Nonevent, nonzero flow; Percentages: Correct, the frequency with which the equation correctly classifies the low-flow statistic for each probability cutpoint; Sensitivity, the ratio of correctly classified events to the total number of events; Specificity, the ratio of correctly classified nonevents to the total number of nonevents; False positive, the ratio of the number of nonevents incorrectly classified as events to the sum of all observations classified as events; False negative, the ratio of the number of events incorrectly classified as nonevents to the sum of all observations classified as nonevents; SAS Institute, Inc., 1995, p. 45-50]

\begin{tabular}{|c|c|c|c|c|c|c|c|c|c|}
\hline \multirow{2}{*}{$\begin{array}{l}\text { Probability } \\
\text { level } \\
\text { (cutpoint) }\end{array}$} & \multicolumn{2}{|c|}{ Correct } & \multicolumn{2}{|c|}{ Incorrect } & \multicolumn{5}{|c|}{ Percentages } \\
\hline & Event & Nonevent & Event & Nonevent & Correct & Sensitivity & Specificity & $\begin{array}{c}\text { False } \\
\text { positive }\end{array}$ & $\begin{array}{c}\text { False } \\
\text { negative }\end{array}$ \\
\hline 0.05 & 57 & 23 & 32 & 0 & 71.4 & 100.0 & 41.8 & 36.0 & 0.0 \\
\hline .1 & 57 & 31 & 24 & 0 & 78.6 & 100.0 & 56.4 & 29.6 & .0 \\
\hline .2 & 55 & 37 & 18 & 2 & 82.1 & 96.5 & 67.3 & 24.7 & 5.1 \\
\hline .3 & 54 & 46 & 9 & 3 & 89.3 & 94.7 & 83.6 & 14.3 & 6.1 \\
\hline .4 & 53 & 47 & 8 & 4 & 89.3 & 93.0 & 85.5 & 13.1 & 7.8 \\
\hline .45 & 52 & 48 & 7 & 5 & 89.3 & 91.2 & 87.3 & 11.9 & 9.4 \\
\hline .5 & 50 & 50 & 5 & 7 & 89.3 & 87.7 & 90.9 & 9.1 & 12.3 \\
\hline .6 & 48 & 50 & 5 & 9 & 87.5 & 84.2 & 90.9 & 9.4 & 15.3 \\
\hline .7 & 44 & 51 & 4 & 13 & 84.8 & 77.2 & 92.7 & 8.3 & 20.3 \\
\hline .8 & 41 & 52 & 3 & 16 & 83.0 & 71.9 & 94.5 & 6.8 & 23.5 \\
\hline .9 & 34 & 53 & 2 & 23 & 77.7 & 59.6 & 96.4 & 5.6 & 30.3 \\
\hline .99 & 24 & 55 & 0 & 33 & 70.5 & 42.1 & 100.0 & .0 & 37.5 \\
\hline
\end{tabular}



Publishing support provided by the U.S. Geological Survey Publishing Network, Columbus Publishing Service Center

For more information concerning the research in this report, contact the Director, Kentucky Water Science Center

U.S. Geological Survey

9818 Bluegrass Parkway

Louisville, Kentucky 40299

http://ky.water.usgs.gov/ 
옹 